\title{
Coordinated protein and DNA remodeling by human HLTF and comparison of its activity with Bloom Syndrome helicase protein
}

\author{
Ph.D thesis
}

\section{Yathish Jagadheesh Achar}

\author{
Supervisor: Dr. Haracska Lajos
}

Institute of Genetics

Biological Research Center of the Hungarian Academy of Sciences

University of Szeged

Szeged 2011 


\section{Table of contents}

I. List of abbrevations

II. List of figures

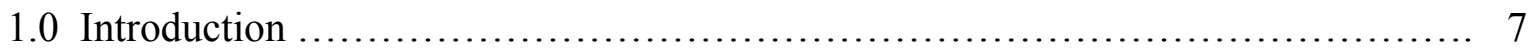

1.1 DNA replication, mutagenesis and cancer 7

1.2 DNA damage and repair $\quad 8$

$\begin{array}{ll}1.3 \text { DNA repair mechanism } & 10\end{array}$

1.4 DNA damage tolerance mechanism 14

1.5 Rad6-Rad18 damage tolerance pathway 17

$\begin{array}{ll}1.6 \text { Replication fork regression } & 21\end{array}$

1.7 Helicases \& Translocases in fork regression 25

1.8 HLTF-The helicase like transcription factor 31

1.9 BLM-The bloom syndrome helicase 33

2.0 Goals and objectives................................................. 35

3.0 Materials and methods.............................................. 36

$\begin{array}{ll}3.1 \text { Proteins } & 36\end{array}$

3.2 DNA substrates 38

3.3 Protein bound DNA substrates $\quad 40$

3.4 Fork reversal assay $\quad 40$

3.5 Protein displacement assay 41

$3.6 \mathrm{Gel}$ retardation assay $\quad 41$

3.7 ATPase assay 41

4.0 Results and conclusions.................................................. 42

4.1 Comparison of HLTF and BLM activity on modeled replication fork 42

4.1.1 HLTF and BLM can regress a homologous fork equally 42

4.1.2 Small heterology at the arm can inhibit HLTF partially, but not BLM 44

4.1.3 Complete heterology on the arms can inhibit HLTF but not BLM 46

4.2 Conclusions from oligo based modeled forks 48 
4.3 Comparison of HLTF and BLM activity on protein bound DNA substrates 49

4.3.1 HLTF can regress a modeled replication fork bound by dsDNA 50 binding protein

4.3.2 HLTF can regress a modeled replication fork bound by ssDNA binding protein

4.3.3 HLTF can dislodge PCNA, RFC \& RPA complex from DNA replication fork

4.4 Protein displacement activity of HLTF 58

4.5 Conclusions from protein bound model forks $\quad 60$

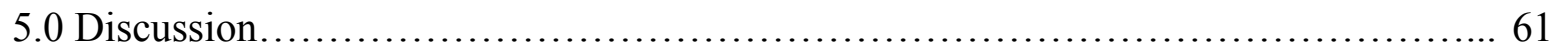

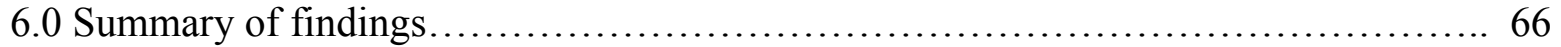

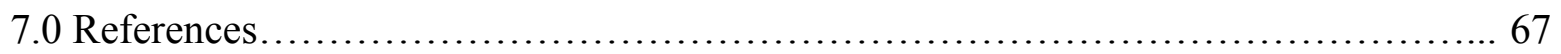

8.0 Acknowledgement.................................................... 85

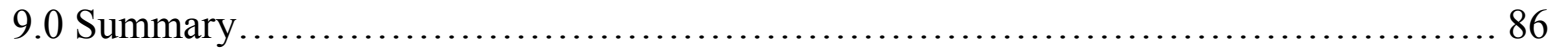

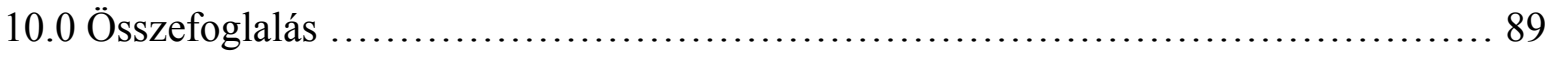




\section{List of abbreviations}

8-oxo-G: 8-oxo-guanines

AP sites: apurinic/apyrimidinic

ATP: Adenosine triphosphate

BER: Base excision repair

BLM: Blooom syndrome helicase protein

CPD: Cyclobutane pyrimidine

DNA: Deoxyribonucleic acid

DSBs: Double strand breaks

dsDNA: Double strand DNA

E.coli: Escherichia coli

EcoRI E111Q: Escherichia coli E111Q EcoRI endonuclease mutant protein

FANCM: Fanconi anemia, complementation group M

GCR: Gross chromosomal rearrangement

GST: Glutathione $S$-transferase

HARP: HepA-related protein

HIV: Human immunodeficiency virus

HLTF: Helicase like transcription factor

HR: Homologous Recombination

MGMT: Methylguanine DNA methyltransferase

MMR: Miss match repair

NER: Nucleotide excision repair

NHEJ: Non Homologous End Joining

PCNA: Proliferating cell nuclear antigen

RAD18: Radiation sensitivity protein 18

RAD5: Radiation sensitivity protein 5

RAD51: Radiation sensitivity protein 51

RAD52: Radiation sensitivity protein 52

RAD6: Radiation sensitivity protein 6

RFC: Replication factor C protein 
RNA: Ribonucleic acid

ROS: Reactive oxygen species

RPA: Replication protein A

SCEs: Sister chromatid exchanges

SHPRH: SNF2 histone linker PHD RING helicase

SSB: Single-strand binding protein

ssDNA: Single strand DNA

SWI/SNF: Switch/Sucrose NonFermentable

TLS: Translesion synthesis

UV: Ultraviolet

WRN: Werner syndrome helicase protein 


\section{List of figures and tables:}

Figure 1. The general outline of the DNA damage response signal transduction pathway.

Figure 2. Overview of DNA damage response

Figure 3. Three major DNA damage tolerance pathways activated upon replication arrest.

Figure 4. An overview of Rad6-Rad18 damage tolerance pathway.

Figure 5. PCNA ubiquitilation as a control mechanism for Rad6-Rad 18 dependent damage tolerance

Figure 6. PCNA ubiquitilation as a control mechanism for Rad6-Rad 18 dependent damage tolerance

Figure 7. A sampling of proposed pathways for replication fork regression upon stalling of replication fork

Figure 8. Schematic representation of yeast and human protein members of Rad5 subfamily

Figure 9. Members of the RecQ family of DNA helicases

Figure 10. Comparison of HLTF and BLM activity on a homologous fork.

Figure 11. Comparison of HLTF and BLM activity on a partial heterologous fork.

Figure 12. Comparison of HLTF and BLM activity on a heterologous fork.

Figure 13. Two different mechanisms of fork regression.

Figure 14. Schematic representation of proteins bound to the DNA when replication fork is stalled.

Figure 15. Sequence specific binding of EcoRI E111Q to modeled replication fork

Figure 16. Fork reversal activity of HLTF on modeled replication fork bound by EcoRI E111Q.

Figure 17. Specific binding of RPA and SSB to ssDNA gap in the modeled fork

Figure 18. Fork reversal activity of HLTF and BLM on modeled replication fork bound by RPA or SSB

Figure 19. Fork reversal activity of HLTF on gapped replication fork like structures bound by replicative proteins PCNA, RFC and RPA

Figure 20. Evidence for dsDNA binding protein disposal from DNA by HLTF

Figure 21. Differential fork regression activity of HLTF and BLM on protein bound substrates

Figure 22. Proposed model for the role of HLTF in remodeling protein-covered stalled replication forks.

Table 1: Summary of the proteins which are known to carry out fork regression activity 


\section{Introduction}

\subsection{DNA replication, mutagenesis and cancer}

All living organisms store their hereditary information in the form of DNA. During cellular division, a complete copy of this DNA must be generated and passed to the daughter cell. This process of replicating the DNA is accomplished by a complex assembly of multiple enzymes and proteins. The proteins involved in this process include helicases, single stranded DNA binding proteins, DNA polymerases, sliding clamps, and clamp loaders (Garg P and Burgers PM 2005). The helicase uses ATP hydrolysis to separate the DNA strands as it moves along the DNA (Hamdan SM \& Richardson and CC.2009). The single stranded DNA binding protein binds ssDNA exposed by the helicase (Wold, MS 1997). The DNA polymerases synthesize the new daughter strand using the parental strand as a template (Kunkel TA \& Burgers PM 2008). The sliding clamp encircles the DNA and enhances the processivity of the DNA polymerases (Langston LD \& O'Donnell M 2008). The clamp loader uses ATP hydrolysis to open the sliding clamp and load it onto the DNA (Chen S et al 2009). These are only a few of the factors involved in DNA replication, but they highlight the complexity of the process.

Accurate DNA replication is essential to the survival of the daughter cell and, in the case of higher eukaryotes, the organism as a whole. When the DNA is replicated inaccurately, it leads to mutations, which can be harmful depending on where in the genome they occur. Most mutations likely occur in regions of the genome that do not affect protein function or expression levels and these are likely neutral. Some mutations, however, could occur in regions of the genome that lead to protein disfunction, and these could be harmful. Particularly harmful mutations can lead to the death of the cell or the improper functioning of a cell in a multicellular organism. A clear example of the latter is carcinogenesis, which often results from mutations in proto-oncogenes and tumor suppressor genes. These mutations are often the result of DNA damage. 


\subsection{DNA damage and repair}

DNA damage (also called DNA lesions) results from both exogenous and endogenous sources. Exogenous sources include ultraviolet radiation (UV), ionizing radiation, and chemical agents. UV radiation, such as that found in sunlight, is the most extensively studied exogenous DNA-damaging agent. Cyclobutane pyrimidine (CPD) dimers are the most frequent type of UVinduced lesions, with thymine-thymine dimers accounting for about 70\% of CPD dimers (Mitchell DL et al 1991, Setlow RB and Carrier WL 1966). If left unrepaired, this lesion is a major block to DNA replication because of the distortion it causes in the DNA backbone (Taylor JS et al 1990). Ionizing radiation also damages the DNA by creating oxygen free radicals that can react with either the DNA backbone or the bases (Ward JF 1990). This results in both single and double stranded breaks, as well as many types of base lesions. These DNA breaks are a major block to DNA replication and, if left unrepaired, can ultimately lead to genomic rearrangement or cell death (Figure 1).

Endogenous sources are the predominate means by which DNA is damaged in the cell under normal conditions. Endogenously generated lesions are mainly produced through hydrolytic and oxidative reactions, which are the consequences of the cellular environment and byproducts of cellular processes. An example of a hydrolytic reaction is the generation of an abasic site resulting in the loss of a base that leaves the sugar phosphate backbone intact. It has been estimated that human cells generate 10,000 abasic sites a day, which can result in mutations or stalling of the replication fork if left unrepaired (Lindahl T 1993; Barnes DE and Lindahl T 2004; Lindahl T and Barnes DE 2000). Oxidative reactions are caused by reactive oxygen species (ROS) often generated by oxidative phosphorylation in the mitochondria. These ROS are highly reactive with DNA and can result in various types of DNA lesions, such as 8-oxo-guanines (8oxo-G), which occur 1000-2000 times per day in a single cell. An 8-oxo-G prefers to form a base pair with an adenine residue in the active sites of DNA polymerases, and this can give rise to transversion mutations if these lesions are replicated (Shibutani S et al 1991, Cheng, K.C et al 1992). These are only a few examples of various types of DNA lesions, but they give an idea of the scale to which DNA damage occurs daily in any given cell. 


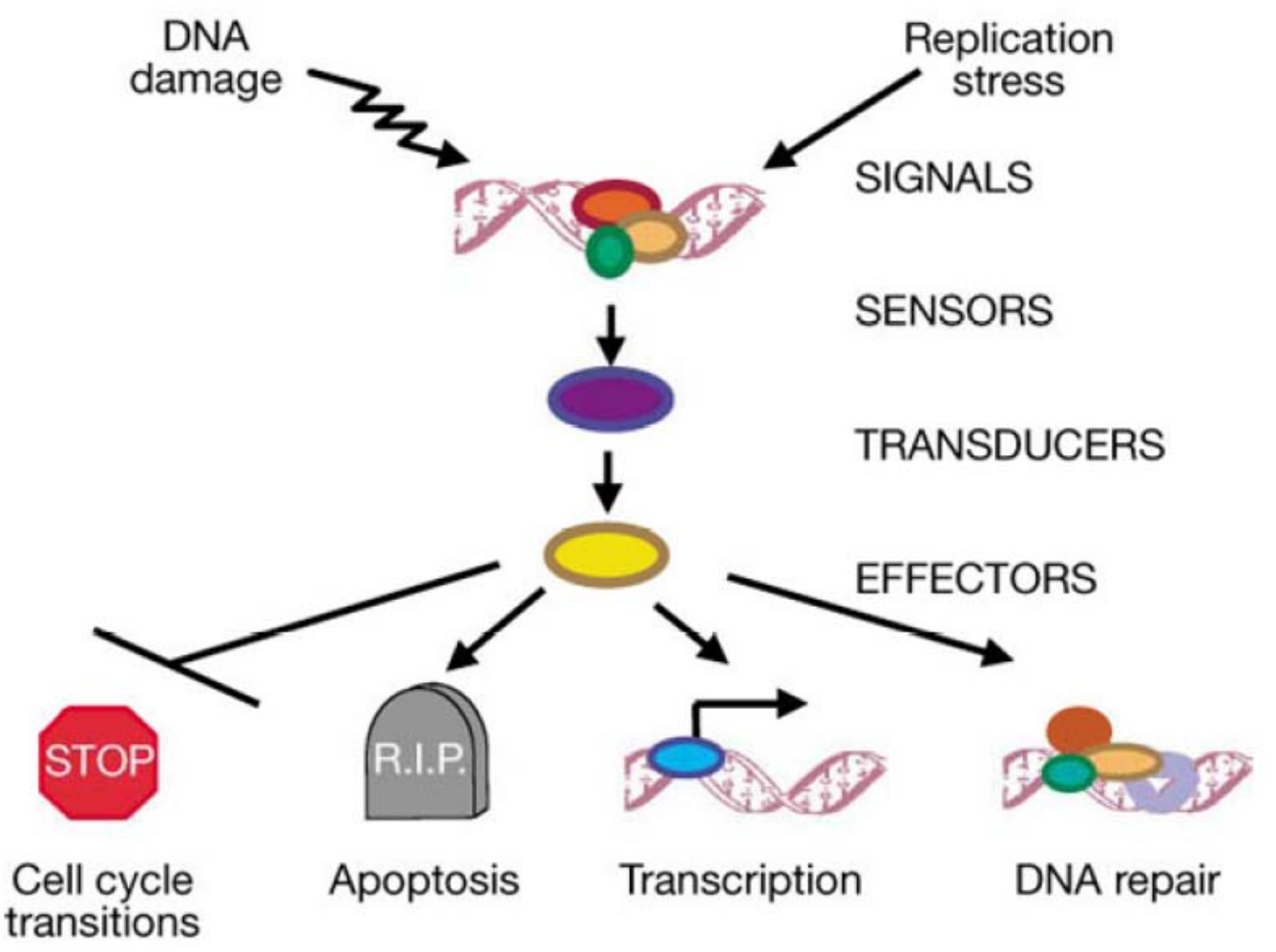

Figure 1. The general outline of the DNA damage response signal transduction pathway.

Adapted from the review article "The DNA damage response: putting checkpoints in perspective" (Zhou and Elledge, 2000).

With so many types of DNA lesions occurring at such a high frequency, the cell has developed multiple biological responses to DNA damage. These processes can be divided into two main categories: DNA repair and DNA damage tolerance. DNA repair is a cellular response to DNA damage that results in the restoration of the normal nucleotide sequence and DNA structure. Even with multiple pathways to repair DNA damage there will persist some amount of damage that must be tolerated during DNA replication. This process of coping with DNA damage is referred to as the DNA damage tolerance pathway. 


\subsection{DNA repair mechanisms}

As there are many different types of DNA lesions, several different kinds of DNA repair mechanisms exist (Figure 2). In general, repair of DNA comes in four varieties. (I) Chemical alterations can be directly reversed by photolyases or methylguanine DNA methyltransferases. (II) The ends of double strand breaks can be resealed by non-homologous end joining. (III) Double strand breaks can also be resolved via recombination with a homologous region within the same cell. (IV) The damaged base can be excised, after which the DNA structure is restored by DNA synthesis using the undamaged strand as a template. (V) Base-base mismatches can be resolved by a separate pathway called miss match repair. Some of the key repair mechanisms are discussed below.

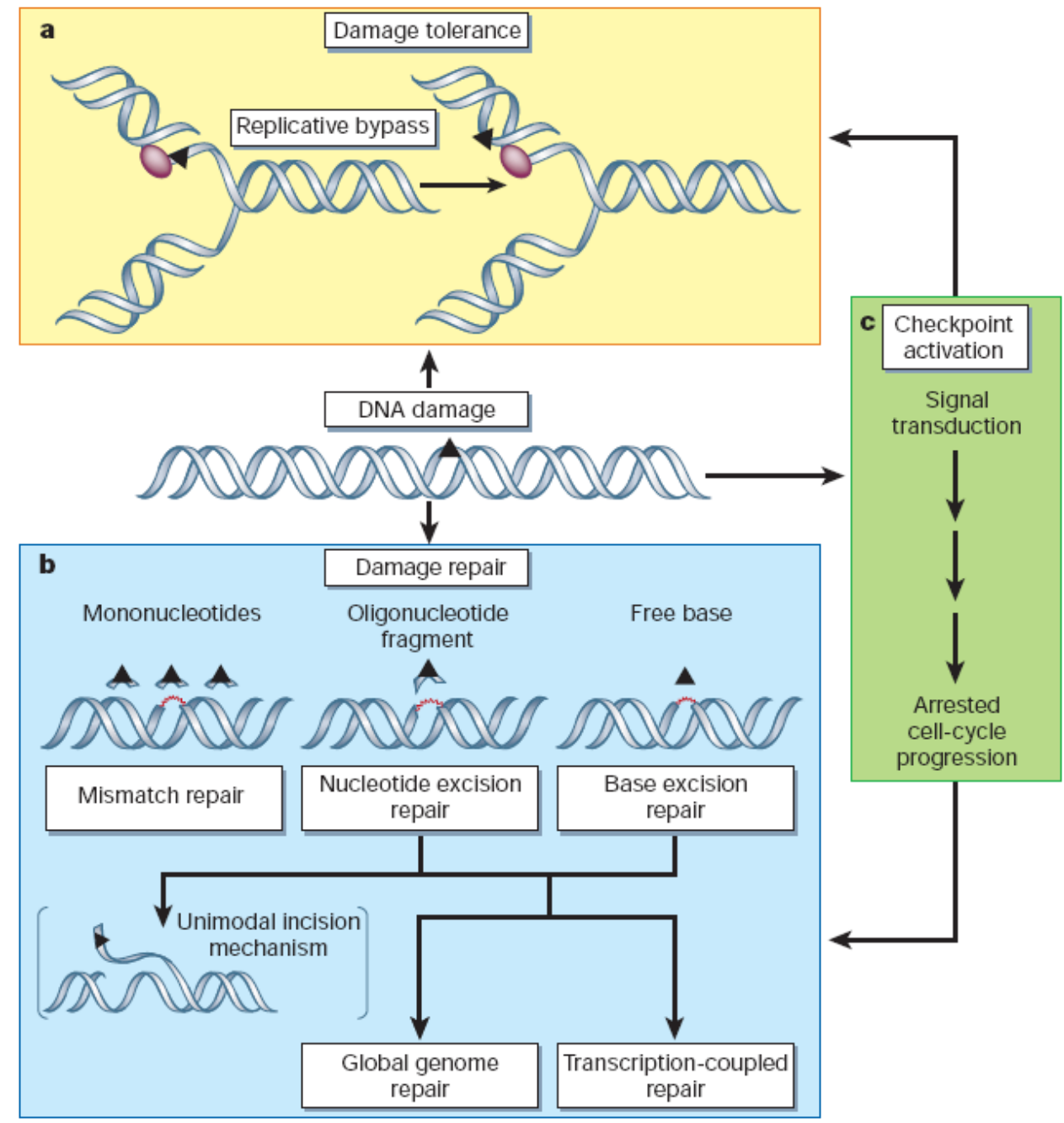

Figure 2. Overview of DNA damage response

Adapted from the review article "DNA damage and repair" (Errol C. Friedberg, 2003). 


\subsubsection{Direct Reversal}

Several proteins were identified that possess the ability to bind damaged nucleotides and reverse the modified nucleotide to its original state. A well known example is CPD-photolyase. This flavoprotein contains two chromophore-cofactors. The chromophore at the surface of the protein enables the protein to use energy from near-UV/blue light as energy source (Mees et al 2004). This energy is utilized via the second chromophore in order to split the cyclobutane ring, thereby restoring the bases to their undamaged state (Sancar 2004).

A different type of direct reversal is employed by methylguanine DNA methyltransferase (MGMT), an enzyme that repairs methylguanines that are frequently formed by alkylating agents. MGMT transfers the methyl group from the guanine to an internal cysteine residue. An MGMT enzyme can only be used once, as the methyl group is stably attached to the cysteine, disabling the enzyme for further repair activities.

For the majority of DNA injuries a direct reversal solution is not available and repair of these lesions rely on other, generally more complex, DNA repair mechanisms.

\subsubsection{Double strand break repair}

Double strand breaks (DSBs) are formed frequently during cellular processes like mitotic recombination, $\mathrm{V}(\mathrm{D}) \mathrm{J}$ recombination and during mating type switching in yeast. Double strand breaks can also be induced by exogenous sources, such as ionizing irradiation and cytotoxins like bleomycin. DSBs are obviously hazardous to the genetic integrity and can lead to a wide range of genetic alterations including loss of heterozygosity, translocations, deletions and even chromosome loss (Jackson 2002). DSBs are dealt with by DSB repair, which is a collective term for two different mechanisms that mend the broken DNA molecule.

Firstly, the sub-pathway responsible for the repair of DSB in the absence of a homologous donor is termed Non Homologous End Joining (NHEJ), a system that directly joins the disconnected DNA ends by ligation. In yeast, the Ku70/Ku80 and MRX complexes stabilize the ends of the DSB, after which the DNA is sealed by DNA ligase (Lewis and Resnick 2000). The simplest mode of NHEJ involves DSBs with complementary overhangs including 5' phosphate and 3' hydroxyl groups, which can be re-ligated error free. Yet, the sealing of most breaks requires processing of the loose ends prior to ligation, resulting in deletions or insertions of 
basepairs. NHEJ is therefore associated with error prone repair of breaks. Despite the error proneness, the NHEJ pathway contributes significantly to the genome stability and suppression of tumorgenesis (Ferguson et al 2000; Karanjawala et al 1999).

In the presence of a homologous donor sequence within the same cell, a DSB can be restored via a second sub-pathway, Homologous Recombination (HR). This is a complex procedure, requiring a set of genes in the RAD52 epistasis group. Repair is established by DNA synthesis using the homologous sequence as template. After the induction of a DSB, the ends of the DSB are resected 5' to $3^{\prime}$. Once a homologous sequence is detected by means of the Rad51ssDNA nucleoprotein filament, strand invasion of the 3' single strand tails with a homologous DNA molecule, allowing DNA synthesis using the 3' tail as a priming sequence. The D loop, formed as a consequence of the strand invasion is able to pair with the other side of the DSB resulting in a double Holliday junction. The non-invading strand can now be extended and subsequent filling of the gaps, ligation and resolution of the holliday junction re-establishes the double stranded DNA (Heyer 2004; Krogh and Symington 2004). The two DSB-repair systems share the same substrates but the relative activity of the two pathways varies between organisms, cell type and cell stage (Shrivastav et al 2008).

\subsubsection{Nucleotide excision repair}

Substrate versatility is a hallmark of the Nucleotide excision repair (NER) system, as it recognizes and removes many different lesions that are mainly generated by exogenous sources. NER substrates include UV induced CPDs and (6-4)PPs, intrastrand crosslinks and various bulky DNA adducts. The in vitro reconstituted NER reaction requires at least 16 proteins, each performing a specific step in the reaction leading to the removal of the lesion. The damaged DNA is identified by the NER damage sensors, after which a region of DNA surrounding the lesion is unwound to create a single strand bubble of $\sim 30 \mathrm{nt}$. At the junctions of this bubble, single strand incisions are made and the oligonucleotide region containing the lesion is removed. The resulting single stranded gap is then filled by DNA polymerase and sealed by DNA ligase. Given the broad range of substrates it is assumed that NER senses a common feature in the damaged DNA. 


\subsubsection{Base excision repair}

The base excision repair (BER) pathway deals with the majority of base modifications, inappropriate bases and base losses which are endogenously formed with a high frequency (Holmquist 1998). Substrates for the BER system are numerous and include the apurinic/apyrimidinic (AP) sites (Boiteux and Guillet 2004) and the 7,8-dihydro-8-oxoguanine (8-oxoguanine) sites (Fortini et al 2003) which are both the result of injury to DNA via reactive oxygen species. In contrast to NER, BER does not employ the same proteins for each type of substrate. In fact, the BER pathway refers to a large collection of individually operating glycosylases, each capable of removing only one or a few different types of lesions. The

glycosylases remove the damaged base by hydrolysis of the N-glycosylic bond that links the base to the deoxyribose-phosphate backbone. The phosphate backbone of the remaining apurinic/apyrimidinic site is then incised by an AP-endonuclease (Barzilay and Hickson 1995), and DNA polymerase and DNA ligase subsequently complete the restoration of the DNA.

\subsubsection{Mismatch repair}

Mismatch repair (MMR) targets base-base mismatches, and it is essential to all organisms since it maintains the stability of the genome during repeated duplication. Defects in the mismatch repair pathway elevate spontaneous mutability 50 to 1000 fold (Kolodner 1996; Schofield and Hsieh 2003). MutS, MutL, MutH, and UvrD, which are essential components of the MMR pathway, were identified in E. coli through the genetic studies of mutants that showed elevated mutation levels (Cox et al 1972; Wagner and Meselson, 1976). MutS initiates repair by binding to the mismatch base, then forms a heteroduplex complex with MutL to activate a methyl-directed endonuclease system which incises at the hemimethylated dam site of unmethylated strand with MutH and UvrD (Au et al 1992; Iyer et al 2006; Modrich and Lahue 1996). MutS and MutL homologs have been identified in all eukaryotic organisms, including yeast, mouse and human. However, no MutH and UvrD homologs have been found in eukaryotic genomes (Jun et al., 2006). In eukaryotic cells, the MMR pathway requires not only MutS homologs (MSH2-6) and MutL homologs (MLH1-3, PMS1) but also proliferating cell nuclear antigen (PCNA also referred as POL30), exonuclease I (ExoI), replication protein A (RPA), and the DNA polymerase $\delta$ (Flores-Rozas et al 2000; Longley et al 1997; Ramilo C et al 2002). 


\subsection{DNA damage tolerance mechanism}

Some DNA lesions will inevitably escape detection by the various damage surveillance proteins and persist into the S phase. Additionally, DNA damage will also be induced during the replication itself. When lesions are not repaired before $\mathrm{S}$ phase through the BER or NER pathways, replication can stop and cells can die. In this case the cell diverts to an alternative means to cope with these lesions. Several mechanisms collectively referred to as 'DNA damage tolerance', have evolved to resolve the arrested replication machinery on the DNA, some at the cost of inducing mutations (Figure 3).

Since cells have developed mechanisms to tolerate these damages, replication can continue independently of the lesion removal. Because of the fact that the initial damage is not repaired but tolerated, this mechanism is more a damage avoidance way than a true repair pathway. These pathways are also known as 'Post Replication Repair', which is not entirely accurate as the lesion is not removed, but rather bypassed.

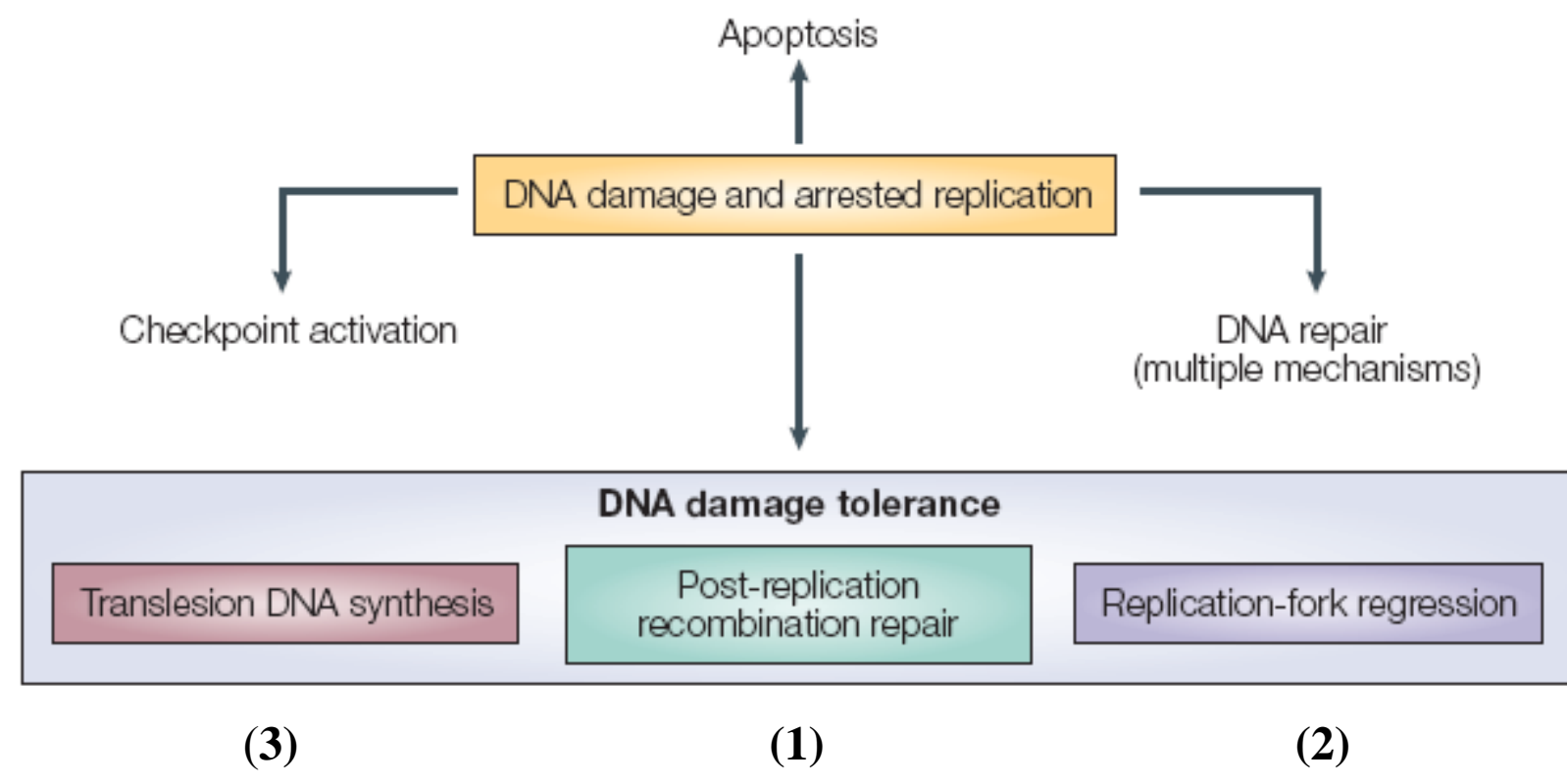

Figure 3. Three major DNA damage tolerance pathways activated upon replication arrest. Adapted from the review article "Suffering in silence: the tolerance of DNA damage" (Errol C. Friedberg, 2005) 
Several types of DNA damage tolerance have been characterized to date, one of which is daughter strand gap-repair, also know as recombinational repair. A current model for this process suggests that the presence of damage precludes direct replication through the lesion, while DNA synthesis resumes downstream of the lesion ( 1000 nucleotides) generating gaps in the damaged daughter strand. These are filled by a recombination event that utilizes the alternative nascent daughter strand as a template (Friedberg EC 2005). Given the highly accurate nature of recombination, this mechanism of DNA damage tolerance avoids the introduction of mutations in newly synthesized DNA and is thus referred to as error-free damage tolerance. This model is well supported with evidence from studies with E. coli, in which the observation was first made that DNA synthesized from damaged templates initially contains discontinuities which are eventually restored to full-length daughter DNA molecules by this process (Johnson RC and McNeill WF 1978).

Another type of damage tolerance mechanism is known as replication fork regression (or copy-choice DNA replication), a unique modality by which a replication fork reorients the template strand used for DNA synthesis without employing genetic recombination (Friedberg EC 2005). Following the detection of a lesion at the replication fork, the replication machinery migrates backwards to allow the original template strands to reanneal so that the strand with the lesion is temporarily synthesized from the other nascent strand. This "copy-choice" replication results in the formation of a variant Holliday junction, called a"chicken foot" structure, which can be restored by reverse regression (Postow L et al 2001; Grompone G et al 2004). Through this process, the original lesion remains in the DNA while an alternative form of replication is performed in an error-free manner.

A third mode of DNA damage tolerance, called DNA translesion synthesis (TLS) employs the replication of DNA directly across sites of template-strand base damage. This mechanism involves one or more specialized DNA polymerases that are capable synthesizing daughter DNA from a damaged template. Specialized DNA polymerases are characterized by reduced fidelity on undamaged DNA, weak processivity, and the inability to proofread (Friedberg EC 2005). Given the nature of these polymerases, DNA translesion synthesis may function in an error-prone fashion, by which new mutations may be introduced into the newly synthesized 
daughter DNA. However, there is a growing body of evidence to suggest that some (possibly all) specialized polymerases may execute DNA translesion synthesis accurately. Whether or not these polymerases function mutagenically in vivo, it appears that the basis of their evolutionary selection is to promote cell survival by overcoming arrested DNA replication.

The modes of DNA damage tolerance described here are representative of the existing body of research regarding this biologically important phenomenon. Given that proteins required for each of these processes are conserved from prokaryotic to eukaryotic organisms, each mechanism may serve a unique and important function in the tolerance of genotoxic stress. While the benefits of error-free post-replicative repair are generally palpable, the advantages of errorprone damage tolerance (particularly in multi-celled organisms) are not as easily reconciled. At least two rationalizations for why organisms may have evolved an error-prone damage tolerance mechanism(s) should be considered. The first suggests that the ability of a cell to increase its mutation rate in response to DNA damage confers an evolutionary advantage, a hypothesis that is particularly well rationalized in unicellular organisms such as bacteria (Friedberg EC et al 2005). A second perspective acknowledges that an error-prone mechanism for damage tolerance may provide a "last line of defense" against the lethal effects of DNA damage, whereby the mutagenic effects are merely a secondary consequence which may bear little evolutionary significance (Lawrence CW and Maher VM 2001; Friedberg et al. 2005). Outside of these reasoning, a possible explanation for the utilization of error-prone translesion polymerases in vertebrates is revealed through the involvement of specialized DNA polymerases in the process of somatic hypermutation, the mutagenic diversification of immunoglobulin genes (Friedberg EC et al 2005). However, error-prone damage tolerance likely ensues outside of early B-cell development. Although DNA damage tolerance as a response to genotoxic stress presents many complexities, it is likely that the fine-tuning of these pathways is critical for cell survival and the avoidance of cancer, and may serve as a driving force for evolution and adaptation (Hochegger $\mathrm{H}$ and Takeda S 2006). It is not known in detail what feature of the stalled replication fork determines which of the above described damage tolerance systems is applied. Different post translational modifications of PCNA were shown to act as molecular switches that determine whether the lesion stalling the replication fork will be bypassed via TLS or repaired via post replication repair (Haracska L et al 2004; Hoege C et al., 2002; Ulrich HD et al 2005; Watts FZ 2006). 


\subsection{Rad6-Rad18 damage tolerance pathway}

The term DNA damage tolerance (DDT) has been employed loosely to include a collection of mechanisms by which cells survive replication-blocking lesions with or without associated genomic instability. Recent genetic analyses indicate that DDT in eukaryotes, from yeast to human, consists of two parallel pathways with one being error-free and another highly mutagenic.

UV-induced DNA damage bypass is best characterized in the baker's yeast Saccharomyces cerevisiae. Genetic studies have indicated that RAD6 and RAD18 are required for both error-free and mutagenic bypass processes, and that they govern at least three different damage bypass pathways (Figure 4) (Prakash S et al 2005; Torres-Ramos CA et al 2002; Prakash L et al 1981): (a) the REV1, REV3, REV7-dependent error-prone translesion DNA synthesis; (b) the RAD30-dependent error-free translesion DNA synthesis; (c) the RAD5-dependent error-free postreplication repair

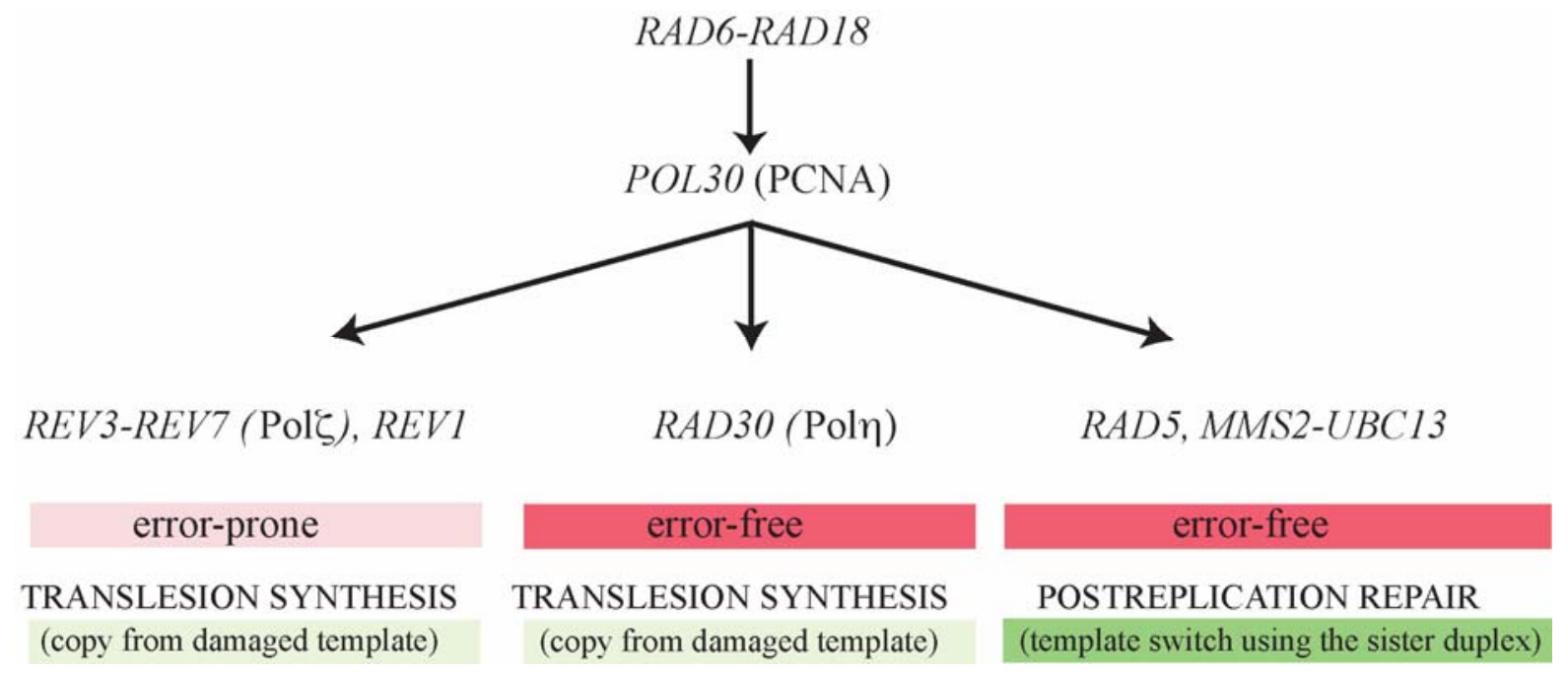

Figure 4. An overview of Rad6-Rad18 damage tolerance pathway.

Adapted from the review article "Role of yeast Rad5 and its human orthologs, HLTF and SHPRH in DNA damage tolerance" (Unk I et al 2009) 
$R A D 6$ and $R A D 18$ play a central role in damage bypass since inactivation of either gene severely impairs both the error-free and mutagenic modes of damage bypass (Lawrence CW 1982; Prakash S et al 1993). Rad6 and Rad18 exist in a tight complex in the cell (Bailly V et al 1994). Rad6 is an ubiquitin-conjugating enzyme (Jentsch $S$ et al 1987), and Rad18 preferentially binds to single-stranded DNA and has ATP-ase and ubiquitin ligase activities (Bailley V et al 1997). The Rad6-Rad18 complex regulates the above three bypass pathways by monoubiquitylating PCNA, a DNA polymerase sliding clamp that is a key component of the replication machinery, at its K164 lysine residue (Figure 6) (Hoege C et al 2002; Stelter P and Ulrich HD 2003). PCNA ubiquitylation by Rad6-Rad18 occurs only when PCNA is loaded onto DNA (Haracska L et al 2006; Wood A et al 2007). Upon DNA damage, the Rad6-Rad18 complex is targeted to the single-stranded DNA region formed due to the stalled replicative polymerase (Bailley V et al 1997; Huttner D and H.D. Ulrich 2008).

$R E V 1, R E V 3$, and $R E V 7$ are responsible for DNA damage induced mutagenesis in yeasts. The Rev1 protein has a deoxycytidyl transferase activity that is however, dispensable for many types of mutagenesis suggesting that in these events Rev1 plays a structural role (Haracska L et al 2002; Haracska L et al 2001; Nelson JR et al 1996(1)). Rev3 and Rev7 comprise polymerase $\zeta$ which functions mainly as an extender in translesion DNA synthesis by extending from nucleotides inserted opposite different DNA lesions by other polymerases (Hashimoto K et al 2004; Johnson RE et al 2000; Nelson JR et al 1996(2)).

$R A D 30$ encodes DNA polymerase $\eta$ that is uniquely able to efficiently and accurately bypass UV-induced cyclobutane pyrimidine dimmers (Johnson RE et al 1999). Accordingly, mutational inactivation of $R A D 30$ causes a rise in the mutagenic bypass of UV lesions (McDonald JP et al 1997; Yu SL et al 2001)

In the $R A D 5$ pathway no translesion synthesis DNA polymerases have been identified. Inactivation of this pathway leads to elevated mutagenesis indicating that replication through lesions are channeled into the mutagenic branch. Beside Rad5, this pathway also involves Mms2 and Ubc13, the latter two forming an ubiquitin-conjugating enzyme complex that assembles polyubiquitin chains linked through lysine 63 of ubiquitin (Figure 6) (Broomfield S et al 1998; 
Hofmann RM et al 1999; Johnson RE et al 1992; Brusky J et al 2000). Rad5 can promote this reaction via its ubiquitin ligase activity that is dependent on its RING domain (Johnson RE et al 1992, Ulrich HD and S. Jentsch 2000; Carlile CM et al 2009; Parker JL and Ulrich HD 2009). Rad5 also has a DNA dependent ATPase activity. It belongs to the SWI/SNF2 family of ATPases and contains seven conserved helicase-like motifs, but shows no activity in canonical helicase assays (Johnson RE et al 1994).

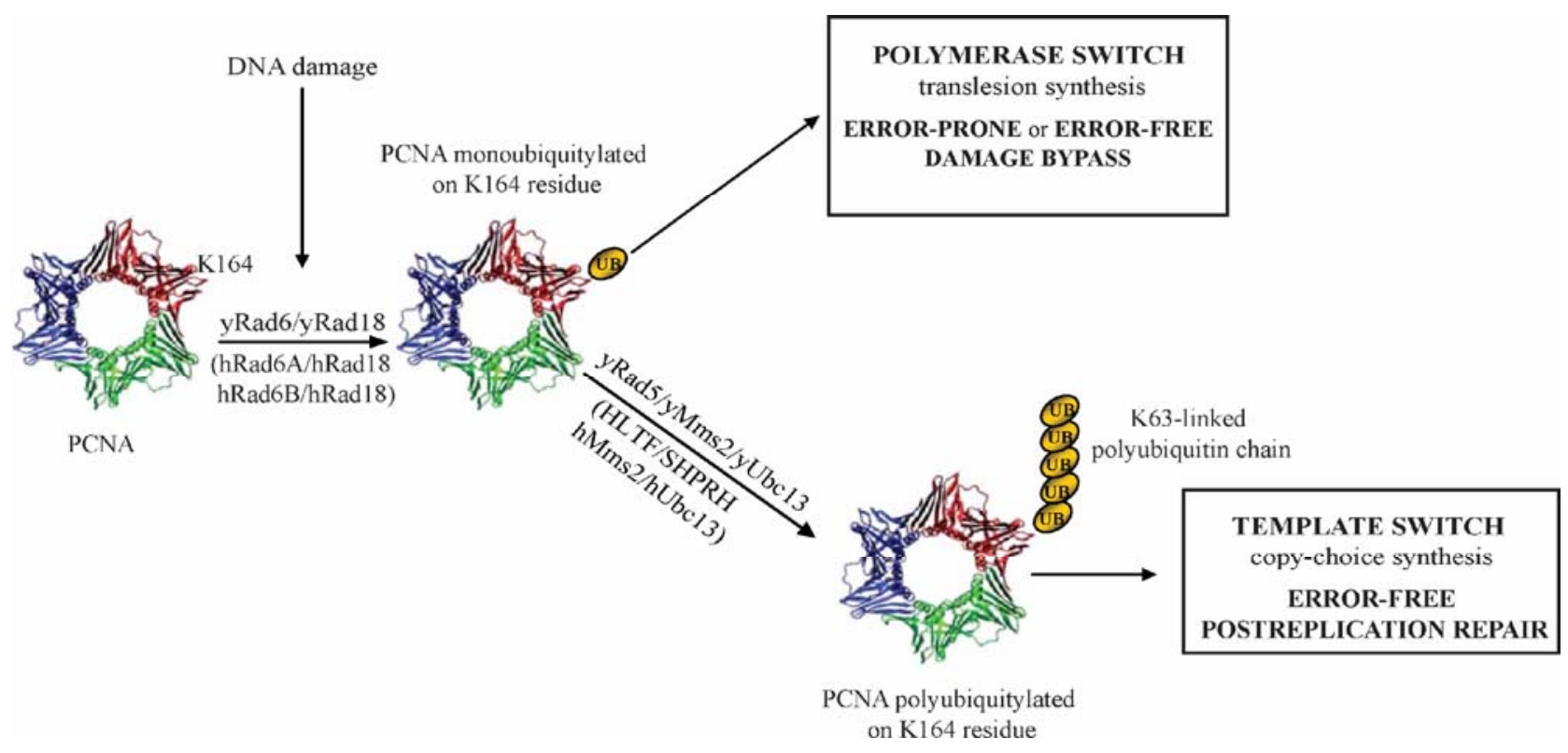

Figure 6. PCNA ubiquitilation as a control mechanism for Rad6-Rad 18 dependent damage tolerance

Adapted from the review article "Role of yeast Rad5 and its human orthologs, HLTF and SHPRH in DNA damage tolerance" (Unk I et al 2009) 
Recent advances in the field revealed that the whole Rad6-Rad18 pathway is controlled by the differential ubiquitination of PCNA by Rad6-Rad18 itself. Upon DNA damage the Rad6/Rad18 complex monoubiquitylates PCNA on its K164 residue. Monoubiquitylation of PCNA is required for switching from a replicative DNA polymerase to a translesion synthesis polymerase which can bypass lesions by an error-free or an error-prone manner. The error-free postreplication repair pathway is activated if Rad5, together with Mms2/Ubc13 builds a K63linked polyubiquinin chain on PCNA already monoubiquitylated by $\operatorname{Rad6} / \operatorname{Rad} 18$. This polyubiquitin-PCNA-dependent pathway provides error-free replication through DNA lesion by template switching using the undamaged sister duplex. The corresponding human homologs of the yeast ubiquitin-conjugating/ligase enzymes are indicated in parenthesis. 


\subsection{Replication fork regression}

In every cell cycle, the replication apparatus encounters numerous chemical and protein blocks that can perturb fork progression (Rothstein $\mathrm{R}$ et al 2000). The consequences of such encounters and the subsequent replication re-start processes employed will depend on both the type of lesion and on the template strand on which the damage resides. Lesions on the lagging strand template can, theoretically, be by-passed via the priming of an Okazaki fragment downstream of the lesion resulting in a gap in the nascent lagging strand. These gaps can then be filled, post-replicatively, by error-prone translesion polymerases or repaired in an error-free manner by homologous recombination (Rothstein R et al 2000; Friedberg EC 2005). Lesions on the leading strand template, however, may cause the replisome to stall. On such occasions, lagging strand synthesis can become uncoupled from leading strand synthesis, with the result that the lagging strand is extended beyond the site of the lesion (Higuchi $\mathrm{K}$ et al 2003; McInerney P et al 2004; Pages V and Fuchus RP 2003; Svoboda D L and Vos J 1995). This apparently futile extension of the nascent lagging strand may actually serve an important role in lesion bypass. If, as proposed, the fork were to regress via annealing of the nascent strands, the longer lagging strand can provide a template for the prematurely terminated leading strand to be extended. In this way, by a process of template switching, leading strand synthesis can be continued beyond the point of the block on the parental template, effectively "bypassing" the lesion. The fork can then be re-established to allow leading strand synthesis to re-commence through either reversal of the regressed fork or recombination-dependent invasion of the regressed arm into the parental template at a point downstream of the lesion (Cox MM 2001; McGlynn P and Lloyd R).

The idea of fork regression was first suggested in 1974 (Hotchkiss RD 1974) and received experimental support in 1976 (Higgins NP et al 1976; Fujiwara Y and Tatsumi M 1976). The formation of heavy/heavy DNA using bromodeoxyuridine pulse-labelling of replicating human cells treated with an alkylating agent or with UV light implied that pairing of the nascent DNA strands could occur during DNA replication (Higgins NP et al 1976; Fujiwara Y and Tatsumi M 1976). Strauss and co-workers (Higgins NP et al 1976) also detected four-armed structures in partially replicated DNA using electron microscopy. These data could be explained by extrusion of a duplex from a replication fork, resulting in the formation of double-stranded DNA in which 
both strands were newly synthesized. Formation of duplexes, containing only nascent DNA, was detected in several subsequent studies (Tatsumi K and Strauss B 1978; Wanka F et al 1977; Nilsen T and Baglioni C 1979; Zannis-Hadjopoulos M et al 1981) but some of this work suggested that branch migration of replication forks was an artefact of DNA extraction or of labelling (Tatsumi K and Strauss B 1978; Wanka F et al 1977). Regardless of whether fork regression could occur in vivo, these studies did highlight the possibility that replication forks had the potential to unwind and form four-stranded DNA structures that resembled Holliday junctions.

The concept of fork regression received little attention during the 1980s, possibly due to the lack of evidence that such a reaction had a physiological role. However, fork regression began to be employed to explain various genetic observations in the 1990s. Hyperrecombination was detected in the replication termination region of the E. coli chromosome (Louarn JM et al 1991) a region in which protein-DNA complexes (Tus-ter) act as pre-programmed polar blocks replication (Neylon C et al 2005). Regression of a blocked fork was proposed to initiate these recombination events, with the extruded fourth arm suggested to be a substrate for recombination (Louarn JM et al 1991). Other work demonstrated that defects in the E. coli replicative helicase DnaB or the putative accessory replicative helicase Rep resulted in the accumulation of doublestranded DNA breaks (Michel B et al 1997) which could be explained by regression and subsequent processing of blocked replication forks (Seigneur M et al 1998). Fork regression has also been invoked to explain genome instability associated with fork blockage in the S. cerevisiae rDNA region (Zou H and Rothstein R 1997; Defossez PA 1999) and processing of forks blocked by transcribing RNA polymerases (McGlynn P and Lloyd RG 2000) and UV light-induced DNA damage (Courcelle J et al 2003) in E. coli. 


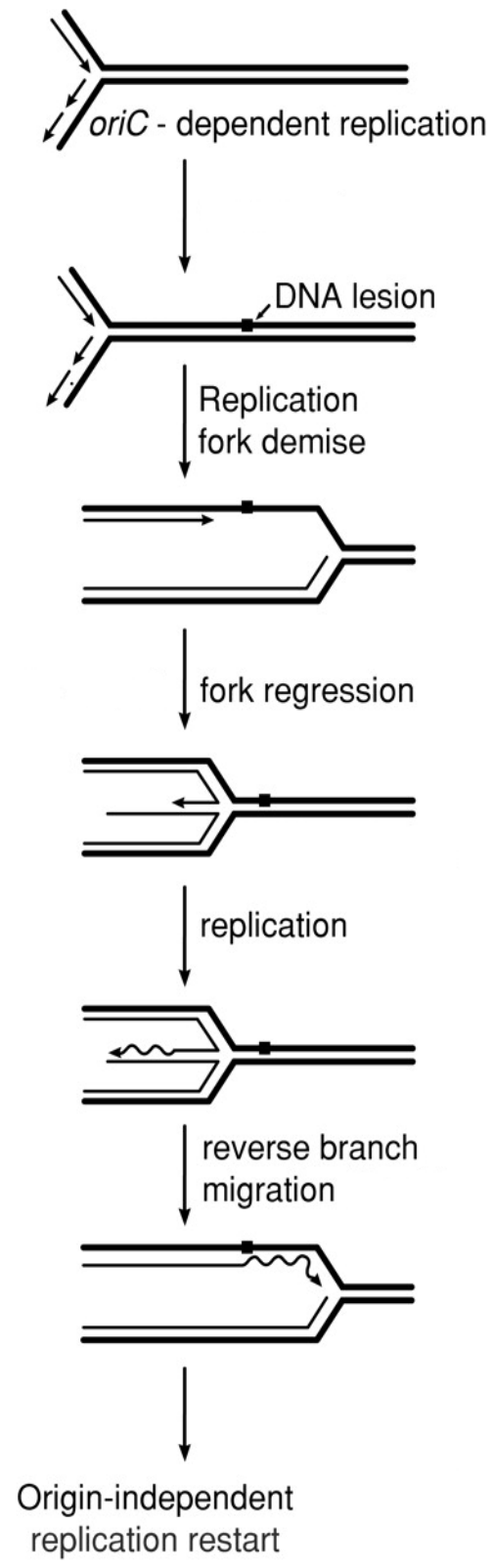

Figure 7. One model proposed for replication fork regression upon stalling of replication fork

Adapted from the review article "The bacterial RecA protein and the recombinational DNA repair of stalled replication forks" (Shelley L. Lusetti and Michael M. Cox 2002) 
This rebirth of the concept of fork regression led to the application of fork regression models to explain, at least in part, many aspects of cell viability, DNA repair and genome stability in relation to the interplay between replication and recombination in E. coli (Coxx MM et al 2000; McGlynn P and Lloyd RG 2002; Michel B et al 2007). Such models were also adopted to explain observations made in eukaryotic systems (Aguilera A and Gomez-Gonzalez B 2008; Wu L and Hickson ID 2006). 


\subsection{Helicases \& Translocases in Fork Regression}

In Escherichia coli, a number of proteins have been shown to promote the regression of stalled forks, which include the DNA helicase RecG and the recombinase protein RecA (McGlynn P and Lloyd RG 2000; Robu ME et al 2001). These proteins are unrelated functionally which suggests that multiple mechanisms may exist to promote fork regression that could be utilized under different circumstances of replication fork repair (Robu ME et al 2001). In eukaryotes, the mechanisms for processing stalled forks are less well characterized. Nevertheless, several lines of evidence indicate that fork regression might occur at eukaryotic replication forks (Sogo JM et al 2002; Zou, H., and Rothstein 1997). Some of the known regressing enzymes in both prokaryotes and eukaryotes are listed in the following table and are discussed briefly in the next segment

\begin{tabular}{|c|c|c|c|c|}
\hline & Gene name & Source & Protein family & Protein function \\
\hline 1 & RecG & E.coli & - & DNA specific Helicase \\
\hline 2 & RuvAB & E.coli & - & Helicase complex \\
\hline 3 & RecQ & E.coli & RecQ & DNA Helicase \\
\hline 4 & SGS1 & S.cerevisiae & RecQ & DNA helicase \\
\hline 5 & DmBLM & D.melenogaster & RecQ & DNA helicase \\
\hline \hline 6 & WRN & H.sapiens & RecQ & DNA helicase \\
\hline 7 & BLM & H.sapiens & RecQ & DNA helicase \\
\hline \hline 8 & RecQ5 & H.sapiens & RecQ & DNA helicase \\
\hline 9 & UvsW & T4-bacteriophage & - & Similar to RecG \\
\hline 10 & RAD5 & S.cerevisiae & SWI/SNF & DNA translocase \\
\hline 11 & HLTF & H.sapiens & SWI/SNF & DNA translocase \\
\hline 12 & HARP & H.sapiens & SWI/SNF & DNA translocase \\
\hline 13 & FANCM & H.sapiens & Superfamily 2 Helicase & FA core complex \\
\hline 14 & FmlI & S.pombe & Superfamily 2 Helicase & FANCM homolog \\
\hline 15 & Hjm/Hel308 & S.tokodaii & Superfamily 2 Helicase & \\
\hline
\end{tabular}

Table 1: Summary of the proteins which are known to carry out fork regression activity. 


\subsubsection{RecG}

This is a branched DNA-specific helicase found in E. coli, the absence of which confers moderate defects in DNA repair and recombination (McGlynn P and Lloyd RG 2002). RecG is also the first enzyme shown to unwind DNA forks to form Holliday junctions in vitro (McGlynn P and Lloyd RG 2000). This monomeric enzyme promotes regression of forked DNA in vitro by simultaneous translocation along the leading and lagging strand templates resulting in coupled unwinding of both daughter strands (McGlynn P and Lloyd RG 2000; McGlynn P and Lloyd RG 2001; McGlynn P et al 2000). Moreover, RecG can catalyse regression of negatively supercoiled in vitro replication intermediates even though such supercoiling inhibits spontaneous fork regression (McGlynn P et al 2001, Slocum SL et al 2007). Analysis of small DNA substrates with heterologous arms indicated that RecG preferentially binds to and unwinds forks with a lagging strand but no leading strand positioned at the branch point (McGlynn P and Lloyd RG 2001) implying that RecG might target forks halted by a leading strand template lesion. However, using forked DNA structures with homologous daughter duplex arms reflecting the homology found in such structures in vivo, RecG promoted efficient regression of forks with varied dispositions of leading and lagging strands at the branch point (McGlynn P and Lloyd RG 2002), Ralf C et al 2006; Machwe A et al 2006). RecG might therefore be able to catalyse fork regression regardless of the disposition of leading and lagging strands at the branch point.

\subsubsection{RuvAB}

This is a helicase complex found in E. coli which, in conjunction with the endonuclease RuvC, branch migrates and cleaves Holliday junctions during the late stages of homologous recombination (Eggleston AK et al 1997; West SC 1997). This specificity for Holliday junctions is reflected in the structure of the RuvAB complex in which a RuvA tetramer binds to one face of a Holliday junction, whilst two hexamers of RuvB each encircle duplex DNA arms emerging from opposing sides of the RuvA tetramer (West SC 1997). Translocation of the RuvB hexamers along the duplex DNA results in branch migration of the DNA substrate, with the DNA 'spooling' across the face of the RuvA tetramer (Hiom K et al 1996; Hargreaves D et al 1998; Yamada K et al 2002). Thus, although RuvAB can catalyse unwinding of a range of branched DNA substrates (Hiom K et al 1996; McGlynn P and Lloyd RG 2001), the structure of the RuvA 
tetramer, the interaction of RuvAB with the RuvC Holliday-junction-specific endonuclease and the roles of RuvA, B and C in DNA repair and recombination indicate RuvAB(C) acts primarily on Holliday junctions (West SC 1997, Hargreaves D et al 1998).

\subsubsection{RecQ family helicases}

These are a highly conserved family of enzymes with key roles in the maintenance of genome stability (Bachrati CZ and Hickson ID 2008). Unicellular organisms tend to contain only a single RecQ family member whereas multi-cellular organisms possess multiple RecQ-type enzymes (Wu L and Hickson ID 2006). The single RecQ helicase found in E. coli, the founding member of this helicase family, does not promote regression of model forks in vitro (Ralf $\mathrm{C}$ et al 2006; Machwe A et al 2006). However, RecQ-type helicases are thought to perform a variety of functions in vivo which may be reflected in the variety of different domains found within members of this family in addition to the highly conserved helicase domains (Hickson ID 2003). Humans lacking the Bloom's syndrome helicase (BLM), a member of the RecQ family, display increased genome instability (Wu L 2007) and, whilst the molecular basis of these phenotypes has yet to be fully established, BLM has been shown to catalyse the regression of model fork structures in vitro (Ralf C et al 2006 ; Machwe A et al 2006). Regression of blocked forks by BLM might provide one mechanism of maintaining genome stability, possibly via template switching to allow replication past ssDNA lesions without running the risk of interchromosomal recombination (Higgins NP et al 1976; Ralf C et al 2006; Machwe A et al 2006). A second human RecQ helicase, WRN, has also been shown to promote fork regression in vitro (Machwe A et al 2006; Machwe A et al 2007). Werner syndrome patients lacking WRN also display elevated levels of genome instability and suffer many phenotypes associated with ageing (Harrigan JA and Bohr VA 2003). WRN also possesses a 3' to 5' exonuclease activity, not seen in other human RecQ helicases, which has been implicated in degradation of the leading strand in model fork substrates (Machwe A et al 2007). Notably, forks containing a gap in the leading strand at the branch point are preferred substrates for WRN-catalysed regression, suggesting WRN exonuclease and helicase activities might co-operate during any fork regression (Machwe A et al 2007). 
As with RecG, BLM and WRN have the ability to unwind a range of branched DNA structures (Opresko PL et al 2004), thus complicating any correlation between phenotypes of cells lacking each helicase and in vitro helicase activities. Indeed, BLM can resolve a recombination intermediate containing a double Holliday junction in concert with human topoisomerase III $\alpha$ (Wu L and Hickson ID 2003) and can also disrupt Rad51-ssDNA filaments (Bugreev DV et al 2007), activities, which could also account for the maintenance of genome stability by BLM. The ability of BLM and WRN to unwind a fork in the direction required for regression can also be inhibited by RPA, a human ssDNA-binding protein, if there is a significant stretch of ssDNA present at the branch point (Kanagaraj R et al 2006). Fork regression activity of BLM and WRN might therefore be restricted to specific blocked fork structures.

\subsubsection{UvsW}

This helicase plays multiple roles in replication and repair of bacteriophage T4 DNA and can also complement many of the phenotypes of E. coli recG strains (Carles-kinch K et al 1997). The DNA substrate specificity of UvsW is also similar to RecG, with forks and Holliday junctions being preferred substrates suggesting that, like RecG, UvsW may catalyse regression of forks (Nelson SW and Benkovic SJ 2007;Webb MR et al 2007). Indeed, UvsW is required for accumulation of regressed forks at a T4 origin of replication in vivo, as detected by gel electrophoresis, and catalyses fork regression in vitro, providing compelling evidence that UvsWdriven fork regression is a physiologically important reaction in T4 (Long DT and Kreuzer KN 2009). However, although UvsW might be functionally similar to RecG, it has no structural homology to RecG outside of the two helicase domains but instead resembles eukaryotic Rad54 (Kerr ID et al 2007). Although Rad54, a Snf2 family translocase, plays a central role in eukaryotic homologous recombination and can unwind various branched DNA substrates (Heyer WD et al 2006), there is currently no evidence that this enzyme is involved in fork regression.

\subsubsection{Rad5 and HARP}

Saccharomyces cerevisiae Rad5 is required for the bypass of UV light-induced DNA damage via a mechanism that does not involve recombination, properties consistent with a template switching mechanism of DNA damage tolerance (Torres-Ramos CA et al 2002). In vitro, Rad5 can promote regression of model fork substrates and branch migration of the resultant 
Holliday junction, consistent with damage tolerance via template switching (Blastyak A et al 2007). Rad5-catalysed regression occurs via concerted unwinding of the daughter strands at the fork (Blastyak A et al 2007) but the enzyme has no detectable helicase activity on non-branched DNA substrates (Johnson RE et al 1994) in contrast to RecG, BLM and WRN.

This feature of Rad5 may be related to it being a member of the Snf2 family of helicases/translocases, many of which translocate along but do not unwind DNA (Flaus A et al 2006). Snf2 enzymes and RecG both define families within the Superfamily 2 of helicases/ translocases (Singleton MR et al 2007) and so it is tempting to speculate that the helicase/ translocase domains of Rad5, like RecG (Singleton MR et al 2001), move along the parental duplex of a fork in an ATP-dependent manner resulting in disruption of daughter duplexes and fork regression.

The recent identification of a human Snf2 family member, HARP, with the ability to reanneal ssDNA bubbles bound by RPA via ATP-driven translocation (Yusufzai T and Kadonaga JT 2008) is also reminiscent of the dsDNA-specific translocation by RecG that can be coupled to fork regression (McGlynn P and Lloyd RG 2001; Singleton MR et al 2007). It has been argued that this HARP annealing activity is distinct from fork regression since HARP does not exhibit helicase activity on partial duplex substrates (Yusufzai T and Kadonaga JT 2008). However, Rad5 is also an ATP-driven translocase that does not possess the ability to unwind partial duplexes but can still regress forks in vitro (Blastyak A et al 2007). The possibility remains therefore that HARP might catalyse fork regression.

\subsubsection{FANCM}

This is a component of the Fanconi anaemia (FA) core complex in humans (Meetei AR et al 2005), disruption of which results in many chromosome instability phenotypes, both spontaneous and damage-induced (Mathew CG 2006). FANCM is a Superfamily 2 helicase that, although it cannot unwind partial duplex substrates (Meetei AR et al 2005), can unwind both forks and Holliday junctions and can also catalyse regression of model forks in vitro (Gari $\mathrm{K}$ et al

2008; Gari K et al 2008). Given that FA cells are especially sensitive to DNA cross-linking agents, FANCM-catalysed regression has been suggested to counter the movement of a replisome 
towards an interstrand cross-link, thus maintaining access of repair enzymes to the lesion (Gari K et al 2008). The Schizosaccharomyces pombe FANCM homologue Fmll can also promote regression of a large model fork, and cells lacking Fml1 are also sensitive to DNA cross-linking agents, demonstrating conservation of in vitro and in vivo function of this motor (Sun $\mathrm{W}$ et al 2008). Moreover, the stripped-down S. pombe system has been employed to demonstrate that Fml1 promotes Rad51 function at blocked forks in vivo leading to a model of Fml1-catalysed regression and template switching followed by Rad51-catalysed recombination of the extruded fourth duplex arm (Sun W et al 2008). However, whether such a model might appertain to human FANCM is unclear.

\subsubsection{Hjm/Hel308}

This is a Superfamily 2 helicase from the archaeon Sulfolobus tokodaii that might also promote regression of forks bearing both leading and lagging strands at the branch point ( $\mathrm{Li} \mathrm{Z}$ et al 2008). However, this reaction appears to be complex since Hjm/Hel308A can promote annealing of complementary DNA strands, and also apparently translocate in both the $3^{\prime}-5^{\prime}$ direction and the 5'-3' direction along ssDNA ( $\mathrm{Li} \mathrm{Z}$ et al 2008). More details concerning this regression reaction are needed.

It is evident that a cell usually harbors more then one kind of fork regressing enzyme, although the exact mechanism and mode of function is largely unknown. One possible hypothesis is that different signal cascades are activated depending on the type of the lesion leading to the stalling of the fork. However this lacks proper experimental data. One of the main goals of this study is to understand if there is any difference between enzymes in regressing a stalled replication fork. To achieve this, two different proteins belonging to separate classes were chosen and are discussed briefly in the following chapters 


\subsection{HLTF- The helicase-like transcription factor}

Many elements of the Rad6-Rad18 dependent DNA damage tolerance have been identified in higher eukaryotes based on sequence homology. In recent years two homologs of Rad5 have been identified in human cells, the HLTF and SHPRH proteins, showing $39 \%$ and $21 \%$ similarities to Rad5, respectively (A. Motegi et al 2006; A. Motegi et al 2008; Unk I et al 2008; Unk I et al 2006).

The helicase-like transcription factor (HLTF), a member of the SWI/SNF family, was discovered to be involved in cancer progression in various ways. HLTF was first described as an ATPase that binds to the SPH repeats of the SV40 enhancer and to the TATA/inhibitor region of the human immunodeficiency virus (HIV)-1 promoter. Therefore it was suggested to function as a transcription factor (P.L. Sheridan et al 1995). Later HLTF was reported to be involved in the transcription of the human plasminogen activator inhibitor-1 and Beta-globin genes (Ding $\mathrm{H}$ et al 1996; M.C. Mahajan and S.M. Weissman 2002). The first link between HLTF and tumorigenesis was established when methylation of the promoter region of HLTF was detected in $43 \%$ of primary colon tumors, suggesting that the inactivation of HLTF is a frequent event in the process of tumorogenesis of the colon (H.R. Moinova et al 2002). The methylation of the HLTF promoter region was associated with loss of HLTF gene expression in some colon cancer cell lines. These results together with the observation that ectopic expression of HLTF suppressed colony growth in each of three different HLTF-deficient cell lines but showed no suppressive effect in any of three HLTF-proficient cell lines suggested that HLTF could be a potential tumor suppressor protein. These findings indicate that HLTF silencing confers a growth advantage and drives the initiation or the progression of cancer formation. More recently, several studies have shown that aberrant methylation of the promoter region of HLTF can be observed in $22-55 \%$ of the digestive tract cancers (T. Fukuoka et al 2006; K. Hibi et al 2003; W.K. Leung et al 2003; N. Oue et al 2006), and that HLTF levels were also very low in some melanoma and leukemia cell lines (C. MacKay et al 2009). Moreover, over expression of various truncated forms of HLTF, which might be dominant negative mutants, has also been observed in different types of cancers (A. Capouillez et al 2009; A. Capouillez et al 2008). 


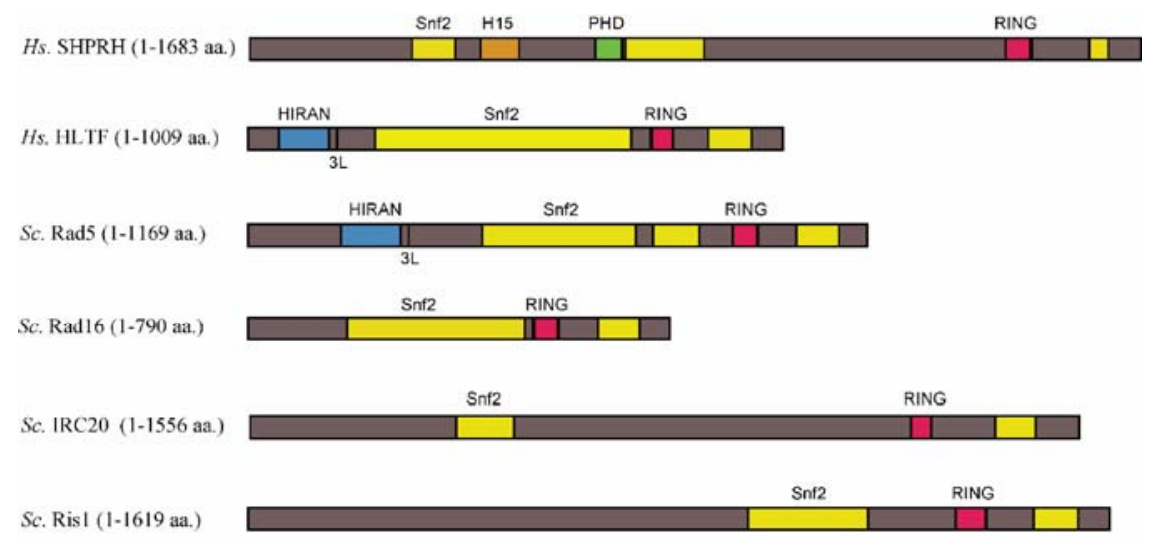

$\square$ H15: linker histone $\mathrm{H} 1$ and $\mathrm{H} 5$ family domain
$\square$ HIRAN : HIP116, Rad5p N-terminal domain
$\square$ PHD: PHD-finger domain
$\square$ RING: RING finger domain
$\square$ Snf2: SNF2 family helicase domain

\section{Figure 8. Schematic representation of yeast and human protein members of Rad5 subfamily}

Adapted from the review article "Role of yeast Rad5 and its human orthologs, HLTF and SHPRH in DNA damage tolerance" (Unk I et al 2009).

Human HLTF share several functional and structural similarities with yeast Rad5. Reduction of HLTF expression enhances DNA damage sensitivity and promotes GCR upon DNA damage, and HLTF is able to partially complement for yeast Rad5 function in a sensitized genetic background (A.Motegi et al 2008; Unk I et al 2008). Moreover, HLTF has a yeast Rad5-like domain structure with a C3HC4 RING domain embedded into a SWI/SNF2 helicase motif. Similarly to other RING domain-containing proteins, HLTF is an ubiquitin ligase which, together with Rad6-Rad18 and Mms2-Ubc13 ubiquitin-conjugating complexes, carries out PCNA polyubiquitylation (Lee KY and K Myung 2008; A.Motegi et al 2008; Unk I et al 2008).

Recent experiments with purified HLTF have further confirmed the high degree of conservation between Rad5 and HLTF, and they revealed that HLTF exhibits essentially the same fork reversal activity as Rad5 (Blastyak A et al 2009). Like Rad5, HLTF does not show any canonical DNA helicase activity on partial heteroduplexes or various heterologous replicationfork-like structures. 


\subsection{BLM- The Bloom syndrome helicase}

The Bloom syndrome (BS) is a rare autosomal recessive disorder with a high predisposition to cancer development. BS was first observed in 1954 (138) and is caused by defects in the BLM gene, located on chromosome 15q26.1 (28). BS is characterized by a stunted growth, including disproportional growth, manifested in a small head and unusual facial and skull growths. Furthermore, male infertility and immunodeficiency, characterised by a decrease in IgA and IgM levels is observed in BS patients. BS patients suffer from a 150-300 fold increase in the risk of developing malignancies of all types.

The Bloom's syndrome (BS) helicase, BLM, has been implicated in the repair of damaged replication forks (Hickson ID 2003). BLM is a member of the highly conserved RecQ family of DNA helicases. The family is named after the E. coli prototypical member RecQ, and members are defined by the presence of a conserved catalytic helicase domain (Bachrati CZ and Hickson ID 2003). Several RecQ helicases also contain additional identifiable motifs, known as the RQC and HRDC domains (Bachrati CZ and Hickson ID 2003). The precise function of these domains is unknown, although they have been implicated in the binding of proteins and/or DNA structures (Bernstein DA and Keck JL 2005; Bernstein DA et al 2003; Brosh RM et al 2001; Liu Z et al 1999; Morozov V et al 1997; Von Kobbe C et al 2002; Wu L et al 2005). In all organisms, RecQ helicases are essential for the maintenance of genome stability with many RecQ helicase mutants displaying replication defects and elevated levels of recombination events (Hickson ID 2003). Indeed, one of the defining characteristics of BS cells is an increased frequency of sister chromatid exchanges (SCEs) (Chaganti RS et al 1974), which are thought to arise from the aberrant repair of damaged replication forks (Hickson ID 2003). 


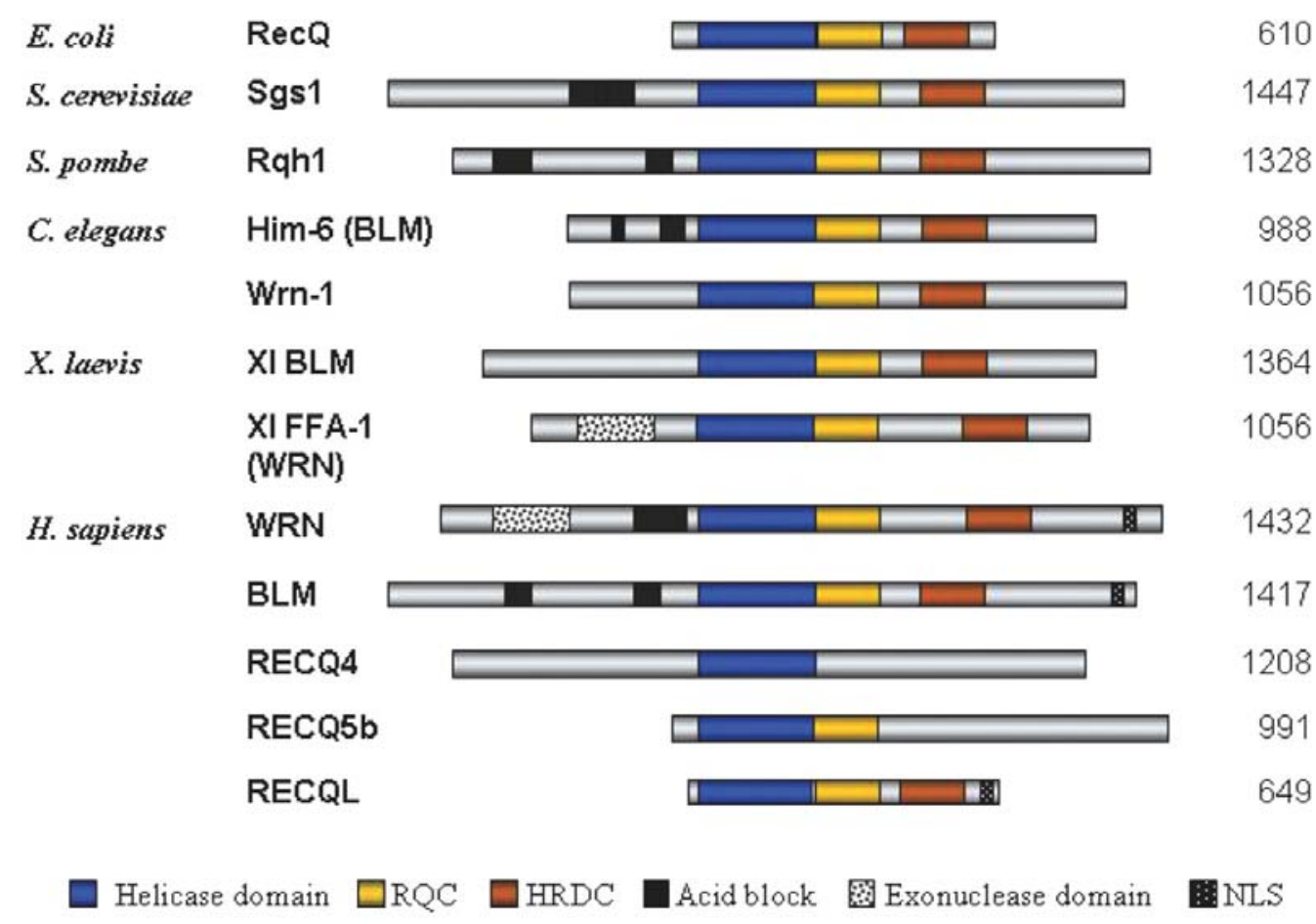

Figure 9. Members of the RecQ family of DNA helicases

Adapted from the review article "RecQ helicases: lessons from model organisms" (Cobb J A and Bjergbaek L 2006)

The BLM protein has been shown to contain three distinct biochemical activities as follows: a 3'-5' DNA unwinding activity, a Holliday junction branch migration activity, and a single-stranded DNA annealing activity (Cheok CF et al 2005; Karov JK et al 1997; Karov JK et al 2000; Machwe A et al 2005). In what role and in which cellular context these activities function remain to be determined. Given that the process of fork regression involves the annealing of the nascent leading and lagging strands to extrude a fourth arm, which can be extended and thus stabilized by branch migration, one possibility is that the three known catalytic activities of BLM might coordinate to promote fork regression 


\section{Goals and objectives}

The main goal of the thesis is to compare the two proteins that have been shown to carry out fork regression activity, namely BLM and HLTF. Although both the enzymes have been shown to carry out fork regression activity on a modeled replication fork, we hypothesized that they might possess different mechanisms to regress a stalled replication fork.

Based on this idea we formulated the specific objectives which are listed below.

I. Since BLM and HLTF belong to different protein families we hypothesized that their mode of regressing a replication fork will also follow different mechanism. To prove our hypothesis we generated different kinds of model replication fork-like structures which will resemble a stalled replication fork. BLM and HLTF are compared on these modeled replication fork-like structures to see if they can process these structures differentially.

II. Most of previous fork reversal studies were carried out on naked replication fork like structures, however, a stalled replication fork contains several single-stranded (ss) DNA- and double-stranded (ds) DNA-bound proteins. How these proteins are displaced before the DNA remodeling occurs has been unknown. So our second goal was to understand the mechanism how a replication fork regressing enzyme overcome the inhibitory effect of protein complex present at the site of DNA replication.

III. Proteins in the Swi2/Snf2 family have been considered as chromatin remodeling enzymes for nucleosome displacement. However no such activity was discovered For HLTF till now, so we investigated if HLTF possess any protein remodeling activity in addition to its DNA remodeling activity. 


\section{Materials and methods}

\subsection{Proteins}

HLTF and BLM proteins were purified as GST-FLAG fusion proteins in yeast. Escherichia coli EcoRI E111Q mutant and hRPA were purified after over expressing in bacteria. Human PCNA and yeast RFC were purified from protease-deficient yeast strain (BJ5464). Escherichia coli SSB was purchased from USB Corporation (Cleveland, Ohio, USA). Purification of individual proteins is described in the following section.

\subsubsection{Purification of HLTF}

Wild-type and ATPase mutant DE557,558AA HLTFs were over expressed as glutathione S-transferase (GST)-FLAG-fusion proteins in protease-deficient yeast strain (BJ5464) using plasmids PIL1520 and PIL1734, respectively (Blastyak A 2010; Unk I 2008 PNAS). Total yeast protein extracts obtained from $5 \mathrm{~g}$ of yeast cells. GST fusion proteins were bound to $100 \mu \mathrm{l}$ glutathione-Sepharose 4B column, and after extensive washing the glutathione-Sepharose 4B beads were incubated overnight at $4^{\circ} \mathrm{C}$ with 5 units of PreScission protease which cleaves GST fusion proteins 7 aa $\mathrm{N}$-terminal from the first methionine, in buffer containing $40 \mathrm{mM}$ Tris $\cdot \mathrm{HCl}$ (pH 7.5), $150 \mathrm{mM} \mathrm{NaCl}, 1 \mathrm{mM}$ DTT, 0.01\% Nonidet P-40, and 10\% glycerol. Finally proteins were checked on a polyacrilamide gel by using comassie staining and were aliquoted and frozen at $-70^{\circ} \mathrm{C}$.

\subsubsection{Purification of BLM}

BLM was overexpressed as GST-FLAG fusion proteins in yeast using plasmid (pIL1863). Total yeast cell extracts prepared using buffer containing $50 \mathrm{mM} \mathrm{KPO} 4,500 \mathrm{mM} \mathrm{KCl,} \mathrm{10 \%}$ Glycerol, 1mM EDTA, 1mM DTT and 0.01\% NP40, were bound to $100 \mu$ glutathioneSepharose 4B column, and after extensive washing the beads were incubated overnight at $4^{\circ} \mathrm{C}$ with 5 units of PreScission protease in buffer the same buffer. Apparently 95\% homogeneous hBLM was obtained and the activity of the purified protein was confirmed by ATPase assay. 


\subsubsection{Purification of E.coli E111Q EcoRI endonuclease mutant protein}

E.coli E111Q EcoRI endonuclease mutant protein was purified according to the original protocol (Cheng SC et al 1984). Briefly, bacterial strain M5248(pSCC2) expressing mutant protein was cultured and the cells were lysed in the breaking buffer containing $20 \mathrm{mM}$ potassium phosphate ( $\mathrm{pH}$ 7.4), $15 \mathrm{mM}$ 2-mercaptoethanol, $1 \mathrm{mM}$ EDTA. The lysate was clarified by centrifugation and solid ammonium sulfate was added to lysate over a period of $30 \mathrm{~min}$, and the suspension was stirred for an additional $60 \mathrm{~min}$. The precipitate was collected by centrifugation, suspended in 1 liter of $20 \mathrm{mM}$ potassium phosphate $(\mathrm{pH} 7.4), 1 \mathrm{mM}$ EDTA, $5 \mathrm{mM} 2$ mercaptoethanol, and dialyzed against $20 \mathrm{mM}$ potassium phosphate $(\mathrm{pH}$ 7.4), $5 \mathrm{mM}$ 2mercaptoethanol, 10\% (w/v) glycerol containing $200 \mathrm{mM} \mathrm{KC1}$ and $0.5 \mathrm{mM}$ EDTA. Dithiothreitol was added to the dialyzed solution.

Dialysed lysate was diluted to 16.1 liters with buffer containing $0.5 \mathrm{mM}$ EDTA and $0.1 \mathrm{M}$ $\mathrm{KC} 1$ and immediately applied at $750 \mathrm{ml} / \mathrm{h}$ to a phosphocellulose column equilibrated with buffer containing $100 \mathrm{mM} \mathrm{KC1}$ and $0.5 \mathrm{mM}$ EDTA. After washing with the same buffer, the column was eluted with a linear gradient of $\mathrm{KCl}(150 \mathrm{mM}$ to $1 \mathrm{M})$ in $20 \mathrm{mM}$ potassium phosphate $(\mathrm{pH}$ 7.4), $5 \mathrm{mM}$ 2-mercaptoethanol, $0.1 \mathrm{mM}$ EDTA, 10\% (w/v) glycerol. Peak fractions were pooled and applied to a column of hydroxylapatite equilibrated with Buffer containing $200 \mathrm{mM} \mathrm{KCI}$. After washing with $150 \mathrm{mM}$ potassium phosphate ( $\mathrm{pH} 7.4), 5 \mathrm{mM}$ 2-mercaptoethanol, 10\% (w/v) glycerol column was eluted with a linear gradient of potassium phosphate $(\mathrm{pH} 7.4,150$ to 800 $\mathrm{mM}$ ) containing $5 \mathrm{mM}$ 2-mercaptoethanol and 10\% (w/v) glycerol. Peak fractions were dialyzed against 3 liters of $20 \mathrm{mM} \mathrm{KP0}_{4}$ (pH7.4), $400 \mathrm{mM} \mathrm{KCI,} 1 \mathrm{mM}$ EDTA, $0.2 \mathrm{mM}$ dithiothreitol, 10\% (w/v) glycerol at $4^{0} \mathrm{C}$ for $4 \mathrm{~h}$ and then against 3 liters of the same buffer in which the glycerol concentration was $50 \%(\mathrm{v} / \mathrm{v})$ for $4 \mathrm{~h}$. Dailysed samples are aliquoted and stored at $-20^{0} \mathrm{C}$

\subsubsection{Purification of human replication protein A (RPA)}

Human RPA was purified according to the original protocol (Henricksen LA et al 1994). Briefly RPA was over expressed in bacteria and harvested cells were lysed in sonicator in HI-50 buffer containing $0.03 \mathrm{M}$ Hepes pH 7.8, 0.00025 M EDTA, 10\% Glycerol, $0.05 \mathrm{M} \mathrm{KCl,} \mathrm{0.01 \%}$ NP-40 and 0.001 M DTT. The supernatant clarified after centrifugation was applied to a 10-ml Affi-Gel blue column equilibrated with $\mathrm{HI}$ buffer containing $0.050 \mathrm{M} \mathrm{KCl}$. The column was 
washed sequentially with $50 \mathrm{ml}$ each of $\mathrm{HI}$ buffer containing $0.05 \mathrm{M} \mathrm{KCl}, 0.8 \mathrm{M} \mathrm{KCl}, 0.5 \mathrm{M}$ $\mathrm{NaSCN}$, or 1.5 M NaSCN. Peak fractions containing rhRPA were pooled and dialyzed against 2 liters of $\mathrm{HI}$ buffer containing $0.05 \mathrm{M} \mathrm{KC1}$ to a conductance equivalent to $0.01 \mathrm{M} \mathrm{KC1}$. During the dialysis, a significant amount of protein precipitated out of solution. The dialyzed fraction was centrifuged at 12,000 rpm for $20 \mathrm{~min}$. The resulting supernatant was loaded onto a Mono-Q (5/5) column (Pharmacia LKB Biotechnology Inc.), equilibrated with HI buffer containing 0.1 M $\mathrm{KC} 1$. The column was washed with $5 \mathrm{ml}$ of $\mathrm{HI}$ buffer containing $0.01 \mathrm{M} \mathrm{KCl}$ and then developed with a 10-ml linear salt gradient of 0.1-0.4 M KC1. Peak fractions were verified on a polyacrilamide gel by using comassie staining, and were aliquoted and frozen at $-70^{\circ} \mathrm{C}$.

\subsection{DNA substrates}

Oligonucleotide-based DNA substrates were generated by annealing oligonucleotides listed below in various combinations followed by purification from polyacrylamide gel as described (Bachrati and Hickson, 2006). The term heterologous fork (HetF) indicates replication fork-like structures with non-complementary leading and lagging arms while homologous fork (HomF) indicates forks with complementary leading and lagging arms. Whereas gap substrate (GapHomF) indicates a homologous fork with a 15bp gap in the leading arm towards the juncture. Oligonucleotides were used in the following combinations, in which underlined are 5 , 32P-labelled oligonucleotide(s):

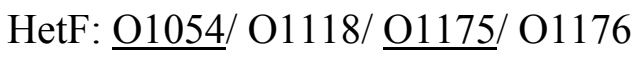

HomF: $\underline{01054 / O 1056 / \underline{O} 1058 / O 1118}$

partialHomF: O1422/O1423/01054/O1118

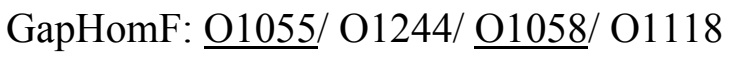

HomF-Biotin: O1054/ O1056/ O1058/ O1118-Biotin

Trap duplex: $\underline{\mathrm{O} 1118 / \mathrm{O} 1058}$ 
Respective sequences of individual oligos are given in 5'- 3' orientation:

O1175:

gATCgTTgCATTCATTCTggAggCCTACggTATgCCTACACTggAgTACCggAgCATCgTCgTgACTgggAAAAC

O1176:

CCgTAggCCTCCAgAATgAATgCAACgATC

O1054:

AgCTACCATgCCTgCCTCAAgAATTCgTAA

O1056:

TTACgAATTCTTgAggCAggCATggTAgCT

O1058:

AgCTACCATgCCTgCCTCAAgAATTCgTAATATgCCTACACTggAgTACCggAgCATCgTCgTgACTgggAAAAC

O1118:

gTTTTCCCAgTCACgACgATgCTCCggTACTCCAgTgTAggCATATTACgAATTCTTgAggCAggCATggTAgCT

O1055:

AgCTACCATgCCTgCCTCAAgAATT

O1244:

TgTAggCATATTACgAATTCTTgAggCAggCATggTAgCT

O1422:

AgCTACCATgCCTgCCTCAAgAATTTACggTATgCCTACACTggAgTACCggAgCATCgTCgTgACTgggAAAAC

O1423:

CCgtaAATTCTTgAggCAggCATggTAgCT 


\subsection{Protein bound DNA substrates}

For dsDNA bound protein substrates homologous fork containing EcoRI binding site(s) $(1 \mathrm{nM})$ was preincubated prior to fork reversal assay with purified E111Q EcoRI $(350 \mathrm{nM})$ in a binding buffer containing $20 \mathrm{mM}$ Tris $\mathrm{pH} 7.5,150 \mathrm{mM} \mathrm{NaCl}, 1 \mathrm{mM}$ DTT, $0.1 \mathrm{mg} / \mathrm{ml} \mathrm{BSA}$, $10 \%$ glycerol at $37{ }^{\circ} \mathrm{C}$ for $15 \mathrm{~min}$. For ssDNA protein-bound substrates, a gap substrate containing a 15-nt gap on the leading arm of the fork $(1 \mathrm{nM})$ was incubated with human RPA $(160 \mathrm{nM})$ or E. coli SSB $(2 \mu \mathrm{M})$ in binding buffer containing $50 \mathrm{mM}$ HEPES 7.8, $150 \mathrm{mM} \mathrm{NaCl}$, $2 \mathrm{mM}$ DTT, $10 \mathrm{mM} \mathrm{MgCl}_{2}, 0.1 \mathrm{mg} / \mathrm{ml} \mathrm{BSA}$ and 10\% glycerol at room temperature for $15 \mathrm{~min}$. For PCNA $(80 \mathrm{nM})$, RFC $(80 \mathrm{nM})$ and RPA $(160 \mathrm{nM})$ bound substrates, all the three proteins were incubated with gap substrates ( $1 \mathrm{nM}$ ) in a buffer containing $20 \mathrm{mM}$ Tris/ $\mathrm{HCl} \mathrm{pH} 7.5,150$ $\mathrm{mM} \mathrm{NaCl}, 1 \mathrm{mM} \mathrm{MgCl}_{2}, 1 \mathrm{mM}$ DTT, $1 \mathrm{mM} \mathrm{ATP}, 0.1 \mathrm{mg} / \mathrm{ml} \mathrm{BSA}$ and $10 \%$ glycerol at $37{ }^{\circ} \mathrm{C}$ for 30 mins.

\subsection{Fork reversal assay}

Fork reversal assays with HLTF $(10 \mathrm{nM})$ and BLM $(10 \mathrm{nM})$ were carried out in buffer H containing $20 \mathrm{mM}$ Tris-HCl, $\mathrm{pH} 7.5,150 \mathrm{mM} \mathrm{NaCl}$ (100 mM NaCl in the case of BLM), $5 \mathrm{mM}$ $\mathrm{MgCl} 2,5 \mathrm{mM}$ ATP, $0.1 \mathrm{mg} / \mathrm{ml}$ bovine serum albumin, $1 \mathrm{mM}$ DTT and $10 \%$ glycerol with $0.5 \mathrm{nM}$ 32P-labeled DNA. Reaction mixtures were incubated at $37^{\circ} \mathrm{C}$ for the time indicated in the figures, followed by adding equal volumes of stop buffer containing $20 \mathrm{mM}$ EDTA, 1\% sodium dodecyl sulfate, $10 \%$ glycerol and $0.02 \%$ bromophenol blue before further incubation for 5 min. DNA samples were loaded onto $10 \%$ native polyacrylamide gels, and the products were separated by electrophoresis using 1x Tris-borate buffer containing no EDTA. 


\subsection{Protein displacement assay}

A homologous fork or a 75/30-mer partial duplex DNA with an EcoRI binding site was generated, in which one of the oligonucleotides was biotinylated (HomF-biotin). E111Q EcoRI $(350 \mathrm{nM})$ was allowed to bind to HomF-biotin $(1 \mathrm{nM})$, followed by binding of this protein-bound fork $(200 \mu \mathrm{l})$ to $50 \mathrm{ul}$ of NeutrAvidin beads (PIERCE-29200) before vigorous washing. Next, fork reversal assay was carried out on the bead-bound fork/ E111Q EcoRI substrate using wildtype HLTF (50 nM) or ATPase mutant DE557, 558AA HLTF (50 nM). 10 ul of supernatant fractions were collected at each time point and incubated with labelled trap dsDNA $(0.5 \mathrm{nM})$ containing a single EcoRI binding site. The displacement of E111Q EcoRI protein was followed by the appearance of a shift due to its binding to trap dsDNA in a gel retardation assay.

\subsection{Gel retardation assay}

Gel retardation assays were performed in binding buffer containing $20 \mathrm{mM}$ Tris-HCl, $\mathrm{pH}$ 7.5, $2 \mathrm{mM} \mathrm{MgCl} 2,0.1 \mathrm{mg} / \mathrm{ml} \mathrm{BSA}, 1 \mathrm{mM}$ DTT and $10 \%$ glycerol using $1 \mathrm{nM}$ 32P-labeled DNA and proteins at increasing concentration as indicated. Reactions were assembled on ice and incubated for $15 \mathrm{~min}$ at room temperature, followed by loading onto a $4 \%$ native polyacrylamide gel containing acrylamide and $\mathrm{N}, \mathrm{N}$ bis-acrylamide in 30:0.8 ratio, $0.5 \mathrm{x}$ Tris-borate and 2.5\% glycerol before gel electrophoresis at $4^{\circ} \mathrm{C}$ in $0.5 \mathrm{x}$ Tris-borate buffer containing no EDTA.

\subsection{ATPase assay}

The reaction (10 ul) was carried out in buffer containing $20 \mathrm{mM}$ Tris- $\mathrm{HCl}(\mathrm{pH} 7.0), 1 \mathrm{mM}$ $\mathrm{MgCl}_{2}, 10 \mathrm{mM} \mathrm{KCl}, 60 \mathrm{dg} / \mathrm{ml}$ BSA, $1 \mathrm{mM}$ DTT, and 10\% glycerol using $40 \mathrm{nM}$ BLM, $1 \mathrm{mM}$ ATP trace labeled with $\left[\mathrm{y}^{32} \mathrm{P}\right] \mathrm{ATP}$, and $0-100 \mathrm{nM}$ DNA. After incubation at $37^{\circ} \mathrm{C}$ for $30 \mathrm{~min}, 1.5$ ul of each sample was spotted onto PEI cellulose F thin layer chromatography plate (Merck), followed by resolving the products using a solvent containing $1 \mathrm{M}$ formic acid and $0.25 \mathrm{M} \mathrm{LiCl}$. 


\section{Results and Conclusions}

One of the main objectives of this study was to compare two proteins HLTF and BLM, belonging to two separate classes of proteins. As discussed before both were previously shown to carry out similar functions during the rescue of a stalled replication fork that is to regress a fork. To find out different mechanisms these two proteins may adopt during the rescue of a fork they were tested with different modeled replication forks. Different kind of modeled forks were put together, by annealing simple oligos to mimic a stalled replication fork. At first BLM and HLTF were tested on a simple naked DNA forks, later tested with protein bound modeled replication forks.

\subsection{Comparison of HLTF and BLM activity on modeled replication fork}

An active fork regressive enzyme can regress a modeled oligo based replication fork and can give rise to two duplex DNA products, a larger parental duplex and a shorter daughter duplex DNA. These two products arise upon concertedly unwinding of both arms of the fork and zipping the parental strand and the nascent daughter strand via a four-way junction called "Chicken-foot". The successful in-vitro fork regression assay then can be confirmed by the appearance of parental and daughter duplex DNA. To compare the activity of HLTF and BLM on a modeled fork, three different kinds of oligo based structures were developed and their differential activities on these different modeled forks will be discussed in the following segment.

\subsubsection{HLTF and BLM can regress a homologous fork equally}

The term homologous fork is referred to the modeled replication fork where both arms of the fork are complimentary to each other and during the course of regression homologous forks are expected to give two simple duplex DNA products. HLTF and BLM can successfully regress a homologous fork giving rise to 75-mer parental and 30-mer daughter duplex DNAs (Figure 10 A). To check if there is any release of single strand DNA, fork regression assays were also carried out in the presence of single strand binding protein (SSB). HLTF regressed fork equally in the presence or absence of SSB (Figure $10 \mathrm{~B}$ ), and there was no evidence that single strand DNA was released during the course of fork regression. However in the case of BLM 30-mer ssDNA could be detected corresponding to the size of the daughter strand. However during the course of time, ssDNA disappears and there was an increase of 30mer dsDNA. 
A.

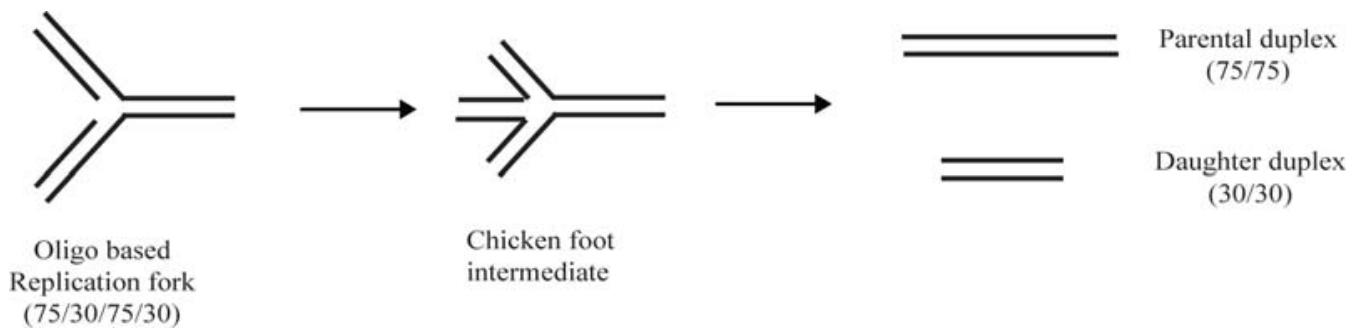

B.
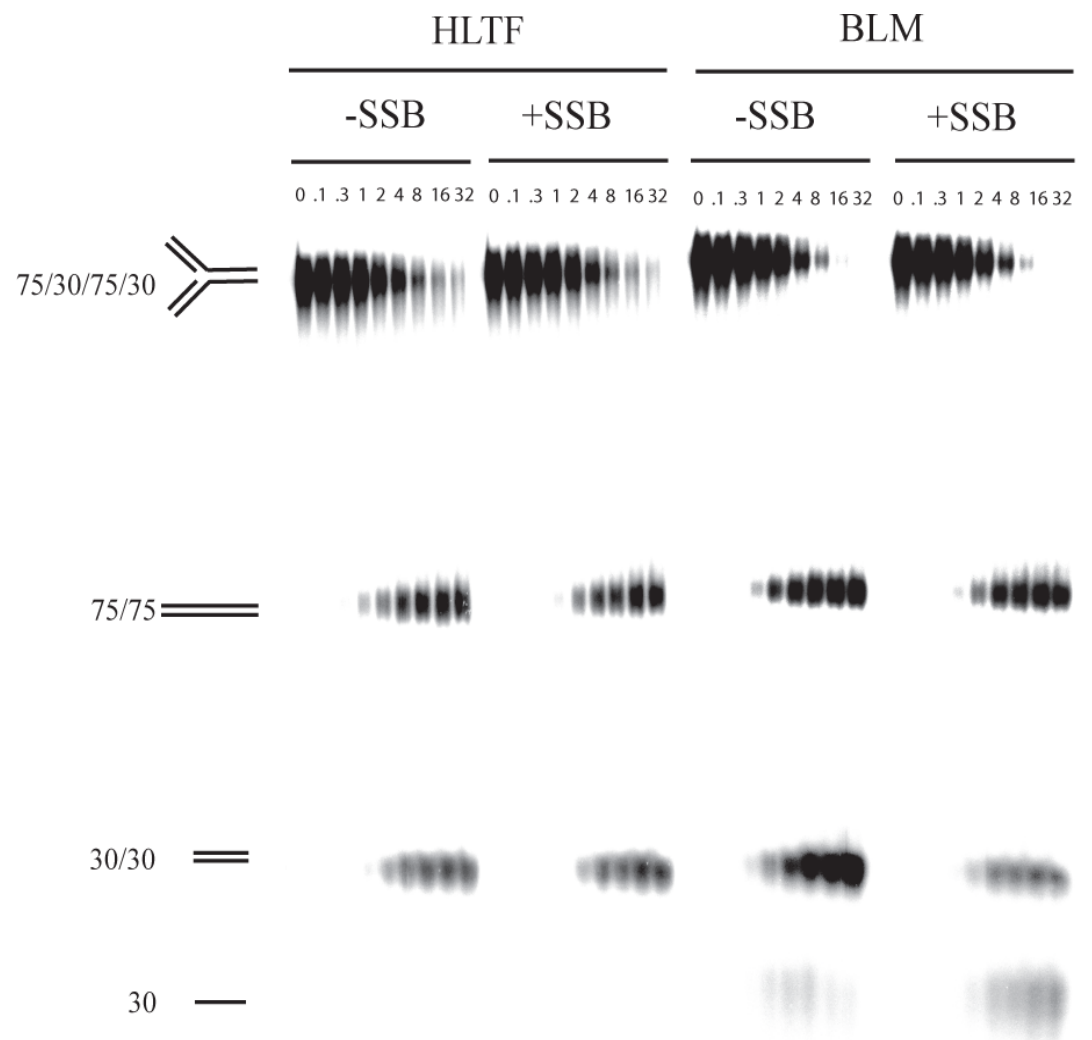

\section{Figure 10. Comparison of HLTF and BLM activity on a homologous fork}

A. Schematic representation of a homologous fork and its regression via a chicken foot intermediate structure. A successful regression will yield a parental duplex and a daughter duplex. The individual lengths of oligos are given in the brackets.

B. Fork regression assay carried out with HLTF and BLM. Each lane corresponds to the time interval of the reaction and is mentioned at the top of the gel. Corresponding oligo structures are shown schematically along with their sizes in base pairs. 
This phenomenon can be explained by the fact that BLM, along with its helicase activity also has a strong strand annealing activity which will anneal back 30-mer ssDNA to give a 30mer dsDNA. However in the presence of SSB, during the course of time, there was an increase in the amount of ssDNA and decrease of dsDNA, which clearly suggest the evidence of strand annealing activity.

\subsubsection{Small heterology at the arm can inhibit HLTF partially but not BLM}

To see if a presence of small heterology has any effect on HLTF fork regression activity, a $5 b p$ heterology was introduced at the junction of the homologous fork. Upon regression this kind of partial heterologous fork will give rise to a 75/75 parental duplex with a bubble in the middle, whereas daughter strand will give a simple "Y" like structure (Figure 11A). Compared to homologous fork HLTF showed considerable less activity on partial heterologous fork (Figure 11B). Like in the case of homologous fork, presence of SSB showed no effect on HLTF. However BLM could regress a heterologous fork equally well as a homologous fork, slight amount of inhibition what was observed in HLTF was not seen in BLM. The presence of SSB also increases the accumulation of ssDNA in BLM samples.

Small inhibition of regression activity what was observed in HLTF can be explained as $5 \mathrm{bp}$ heterology in the arm can interfere with the formation of the chicken foot intermediate, as it requires the simultaneous release and annealing of daughter strands. In the case of BLM the appearance of ssDNA can be attributed to its activity on a simple bubble structure, and the presence of SSB will inhibit its re-annealing activity of single strand DNAs. 
A.

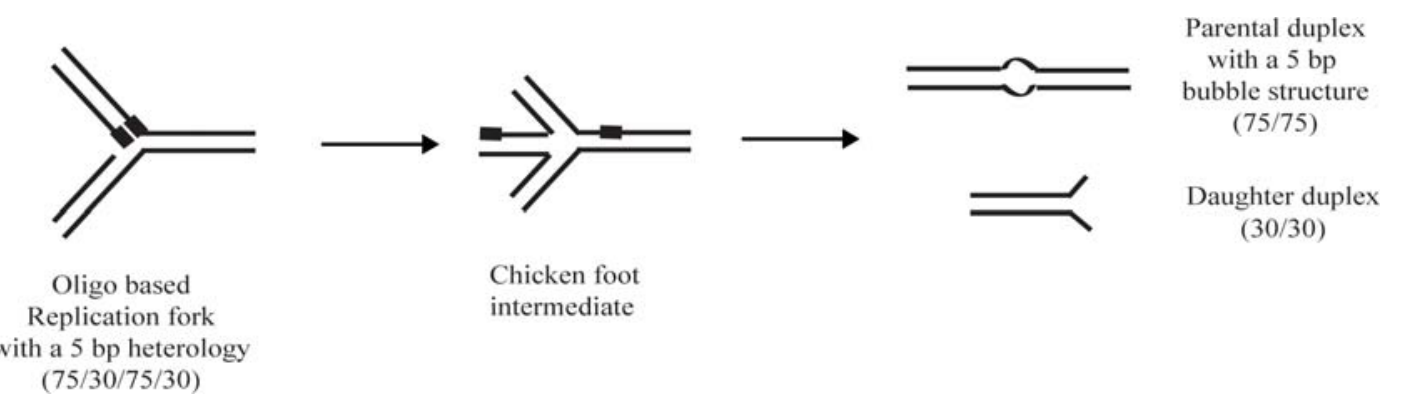

B.

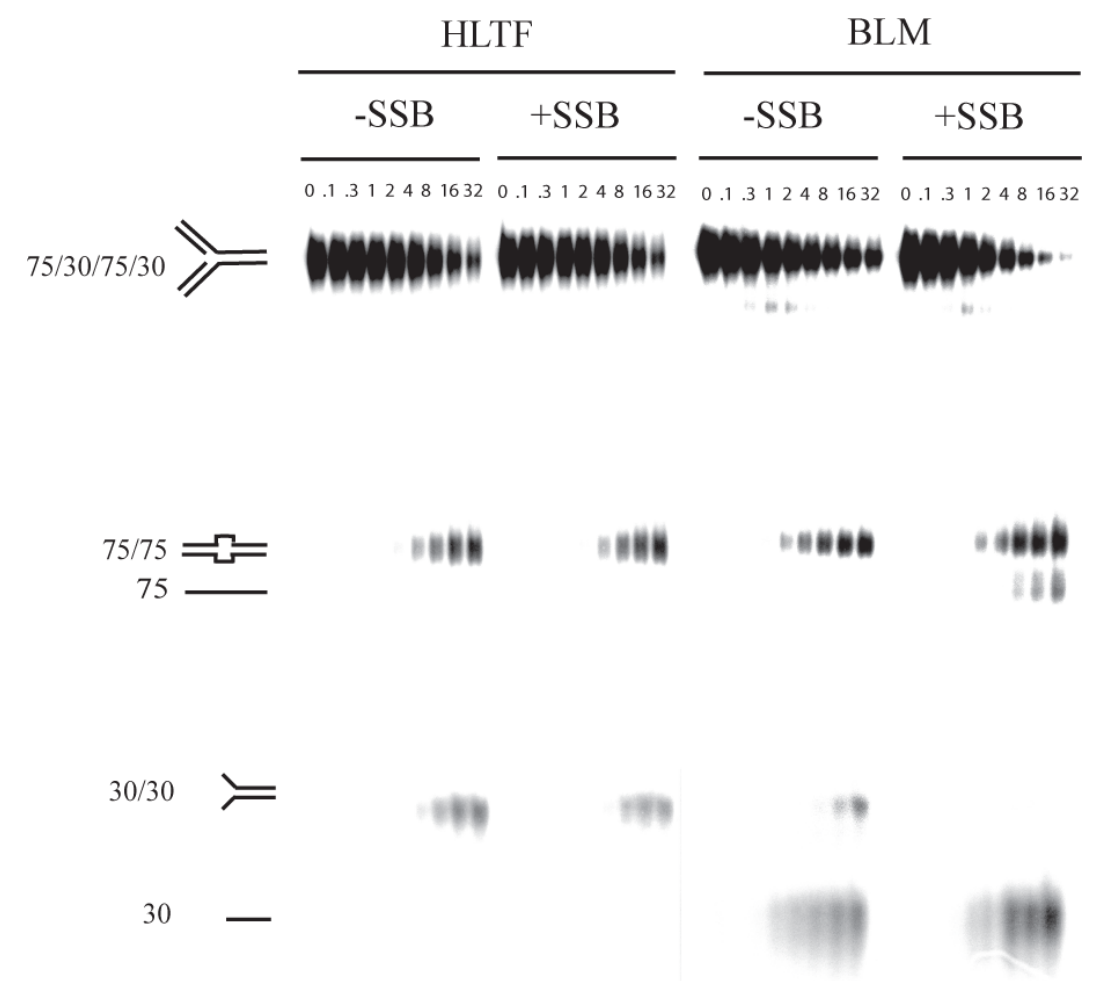

\section{Figure 11. Comparison of HLTF and BLM activity on a partial heterologous fork}

A. Schematic representation of a partial heterologous fork. It is similar to a homologous fork except it contains a non complimentary sequence at the junction of the fork which is represented by a thick line. A successful regression will yield a parental duplex with a 5 bp bubble like structure and a daughter duplex. The individual lengths of oligos are given in the brackets.

B. Fork regression assay carried out with HLTF and BLM on a partial heterologous fork. Each lane corresponds to the time interval of the reactiopn and is mentioned at the top of the gel. Corresponding oligo structures are shown schematically along with their sizes in base pairs. 


\subsubsection{Complete heterology on the arms can inhibit HLTF but not BLM}

Considerable amount of inhibition seen in HLTF on a partial heterologous fork raised the question of its ability to regress a complete heterologous fork. To clarify this point a heterologous fork has been generated, where the two arms of the replication fork are not complimentary to each other (Figure 12A). We found that a complete heterology on replication fork arms blocks the regression activity of HLTF (Figure 12B); it partially inhibited the BLM, where only products visible were simple $\mathrm{Y}$ fork or a partial fork where, only one of the daughter strands was a duplex DNA. However the scenario changes when SSB was included in the reaction, BLM could give rise to different combination of single and partial duplex DNA.

The only possible explanation that could be given for the difference in BLM activity in the presence or absence of SSB is that, BLM rips off the substrate. But due to its strong annealing activity it can reassemble a heterologous fork, however the presence of SSB completely inhibits this phenomenon. One would ask what if BLM first regresses a fork to give a parental duplex and a daughter duplex DNA and then can act on this blunt end products to give ssDNA products. However this situation is unlikely to happen since BLM like any other canonical helicase cannot act on a blunt end DNAs. To rule out this possibility BLM helicase activity was tested on 75/75 and 30/30 duplex DNAs which resemble exactly parental and daughter duplex DNA. 
A.

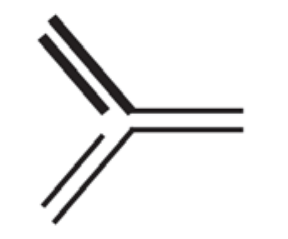

Oligo based Replication fork with non-complementary arms $(75 / 30 / 75 / 30)$

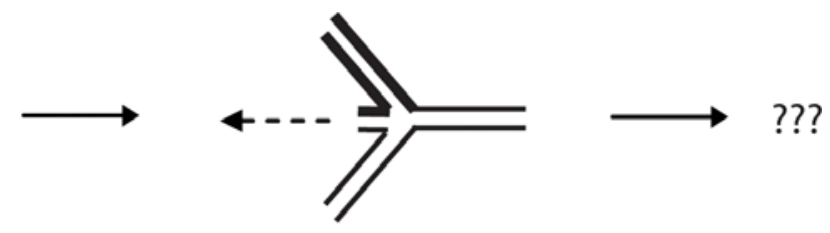

Inhibition of Chicken foot intermediate formation

B.

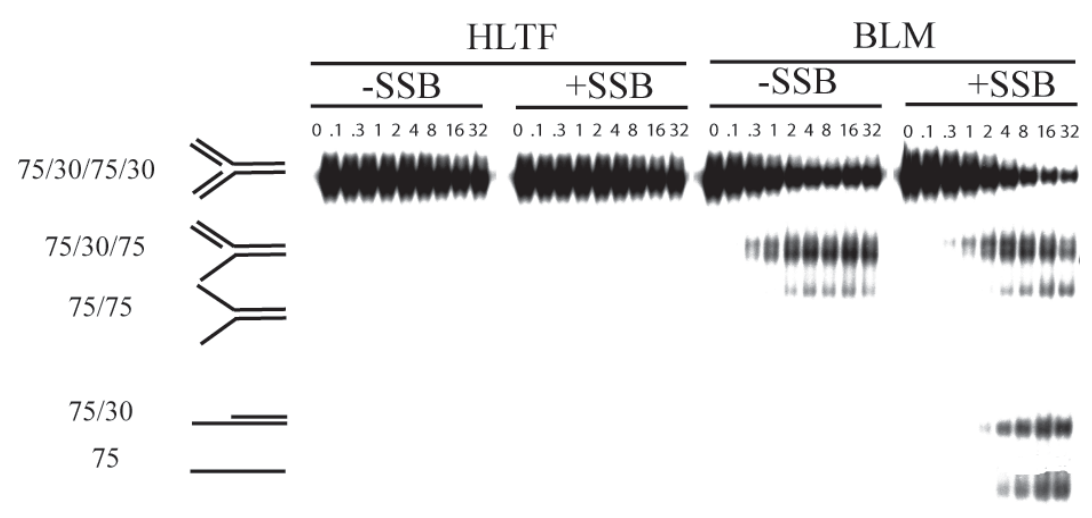

30

\section{Figure 12. Comparison of HLTF and BLM activity on a heterologous fork}

A. Schematic representation of a heterologous fork. The non-complimentary arm is shown in thick lines. Since the arms of the fork are non complimentary to each other, hence inhibition of chicken foot formation.

B. Fork regression assay carried out with HLTF and BLM on a heterologous fork. HLTF was unable to regress a complete hetrologous fork. Where as BLM showed 2 different pattern depending on the presence or absence of SSB. 


\subsection{Conclusions from oligo based modeled forks}

Experiments from oligo based modeled replication fork revealed that HLTF and BLM act on modeled fork very differently. BLM showed no effect when complimentary arms of the fork are changed to partial heterology or to a complete hetrologous fork, whereas HLTF was completely inhibited with a complete heterologous fork and partial inhibition was seen with a partial heterologous fork. BLM acts in a way of dissolving a fork (Figure 13), where HLTF act as a typical fork regression enzyme. Both mechanisms are outlined in the following figure.

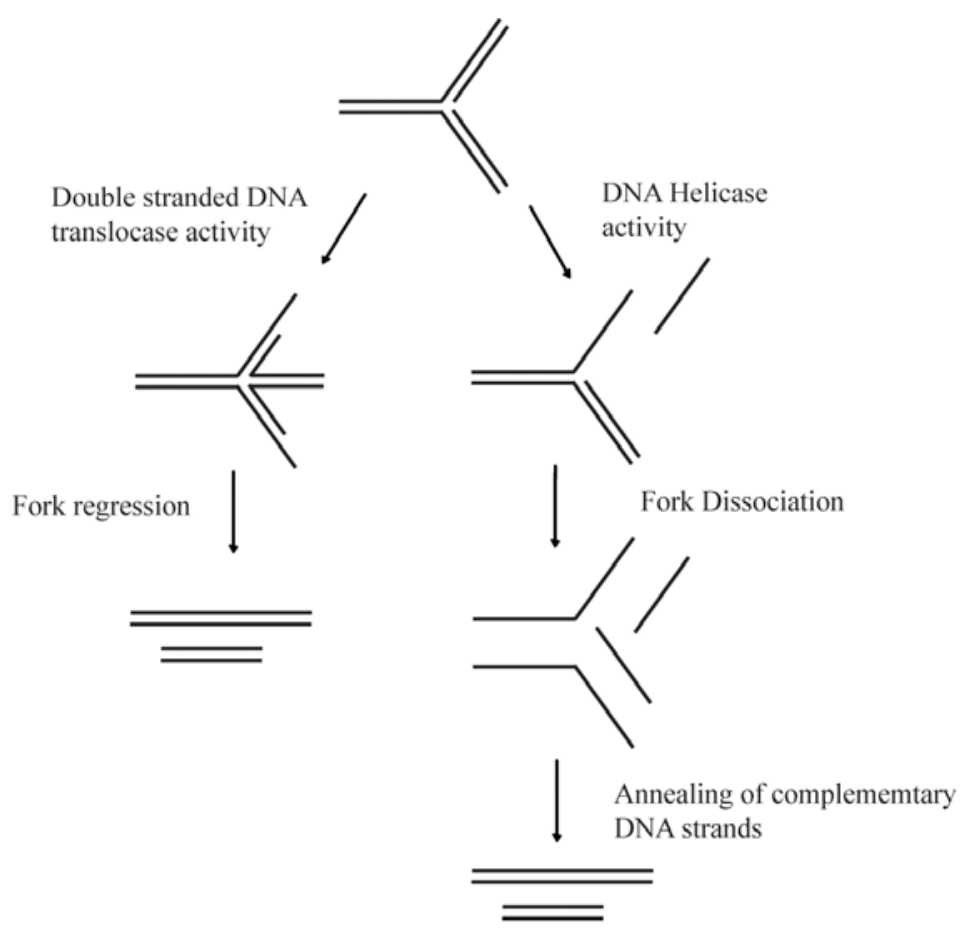

Fork regression

Fork dissolution

\section{Figure 13. Two different mechanisms of fork regression}

A modeled fork can be regressed in 2 ways (I) Fork Regression: which is followed by majority of double strand DNA tarnslocases like HLTF and (II) Fork dissolution: It requires two different enzyme activities one is to separate DNA strands and the second activity is to anneal complimentary strands. 


\subsection{Comparison of HLTF and BLM activity on protein bound DNA substrates}

Most of previous fork reversal studies were carried out on naked replication fork like structures, whereas in vivo a stalled replication fork contains several single-stranded (ss)DNAand dsDNA-bound proteins (Figure 14) such as the replicative polymerases, RPA, RFC, and PCNA which can interfere with DNA remodeling. It is evident that somehow these proteins have to be displaced from the fork for productive template switch and to give access to new damage bypass protein players. It is possible that they become degraded but a more reasonable hypothesis is that these proteins are transiently displaced from the damage site by some protein remodeling mechanism.

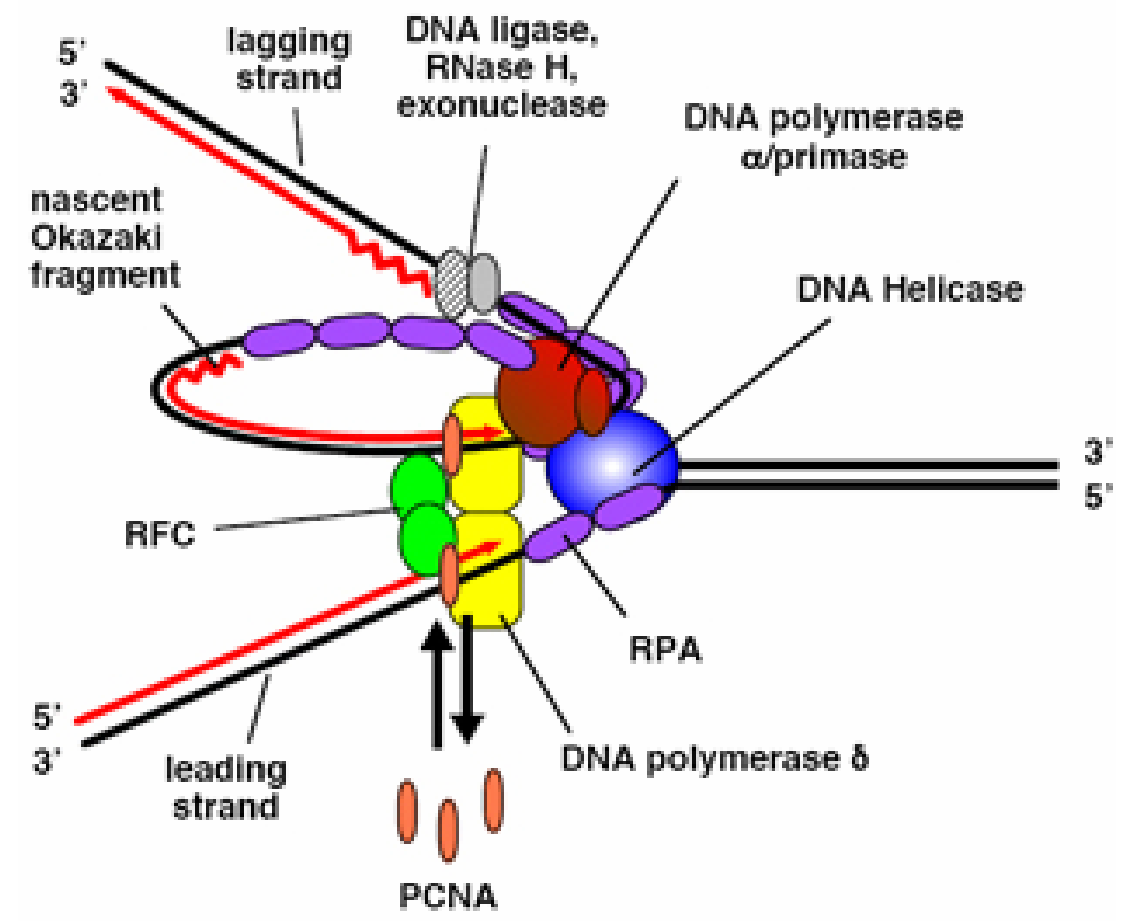

Figure 14. Schematic representation of proteins bound to the DNA when replication fork is stalled. 
In order to establish an experimental system that is closer to the in vivo situation different kinds of proteins, including ssDNA binding and dsDNA binding proteins have been bound to the modeled replication fork and the fork regressing activity of HLTF and BLM was compared.

\subsubsection{HLTF can regress a modeled replication fork bound by dsDNA binding protein}

To examine whether HLTF or BLM DNA remodeling activity is inhibited by a protein bound to stalled replication fork-like DNA structures, oligo based homologous forks were generated to which dsDNA binding proteins can bind. To eliminate the possibility of proteinprotein interaction between a fork regressing enzyme and DNA bound protein E. coli E111Q EcoRI endonuclease mutant protein has been choosen which is selectively defective in DNA cleavage but retains its sequence-specific dsDNA binding activity. An EcoRI recognition sequence was introduced to one or both arms of Homologous fork, and the sequence specific binding of E111Q EcoRI to the homologous fork was confirmed by gel mobility shift experiments (Figure $15 \mathrm{~B}$ ). The remodeling of these protein-bound DNA structures can be followed by the appearance of the 75/75 (parental strands) and the 30/30 (daughter strands) nucleotide-long double-stranded DNA fragments that would arise upon fork reversal as described earlier.

Fork regression assays on this substrate revealed that BLM was completely inhibited by binding of E111Q EcoRI proteins to both arms (Figure 16 A). In contrast, HLTF retained its fork reversal activity on the same protein-bound fork substrate and only weak inhibition occurred. In addition, when the fork DNA contained only a single EcoRI binding site in one of its arms, HLTF processed the leading or lagging strand protein-bound substrates with similar kinetics (Figure 16 B). These results suggest that HLTF can facilitate fork remodeling even when the fork arms are bound by proteins, which represents the actual scenario when the replication fork is stalled. The lack of a similar activity in BLM helicase reveals the specificity of HLTF. 
A.

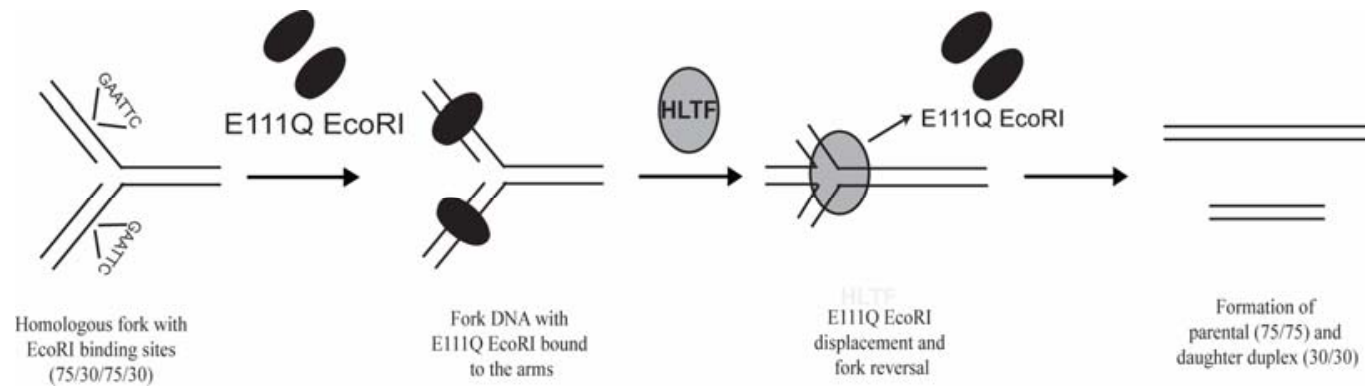

B.

Concentration of E111Q EcoRI (nM)
03570140210350490

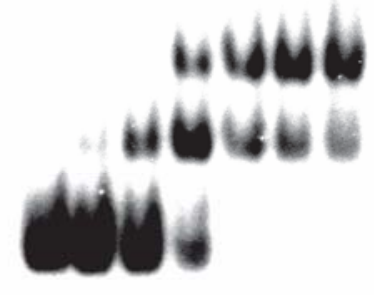

I

EcoRI binding site on both arms

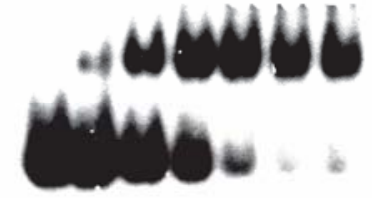

II

EcoRI binding site on lagging arm

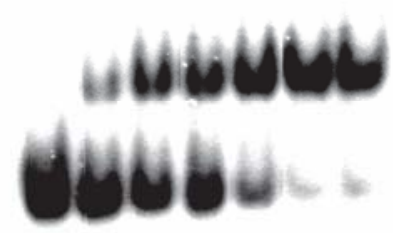

III

EcoRI binding site on leading arm

\section{Figure 15. Sequence specific binding of EcoRI E111Q to modeled replication fork}

A. Schematic representation of a possible mechanism through which HLTF can coordinately remodel a replication fork bound by E111Q EcoRI protein.

B. Gel retardation assay showing sequence-specific binding and formation of stable DNA-protein complex by E111Q EcoRI on oligo based fork like structures. Increasing amount of E111Q EcoRI was incubated with homologous fork containing an EcoRI binding site. Panel I shows E111Q EcoRI binding to both arms of the fork, whereas panel II and III show binding to lagging or leading arm only. 
A.

\begin{tabular}{|c|c|c|c|c|}
\hline \multirow[b]{2}{*}{ + E111Q } & \multicolumn{2}{|c|}{ HLTF } & \multicolumn{2}{|c|}{ BLM } \\
\hline & - E111Q & $+\mathrm{E} 111 \mathrm{Q}$ & - E111Q & $+\mathrm{E} 111 \mathrm{Q}$ \\
\hline
\end{tabular}

${ }_{75}^{7575}=$ ㄷำ

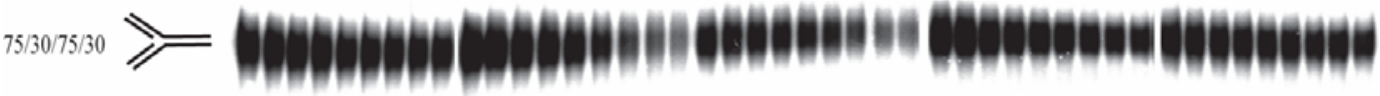

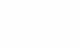

$\begin{aligned} 30 / 30 & = \\ 30 & =\end{aligned}$

B.

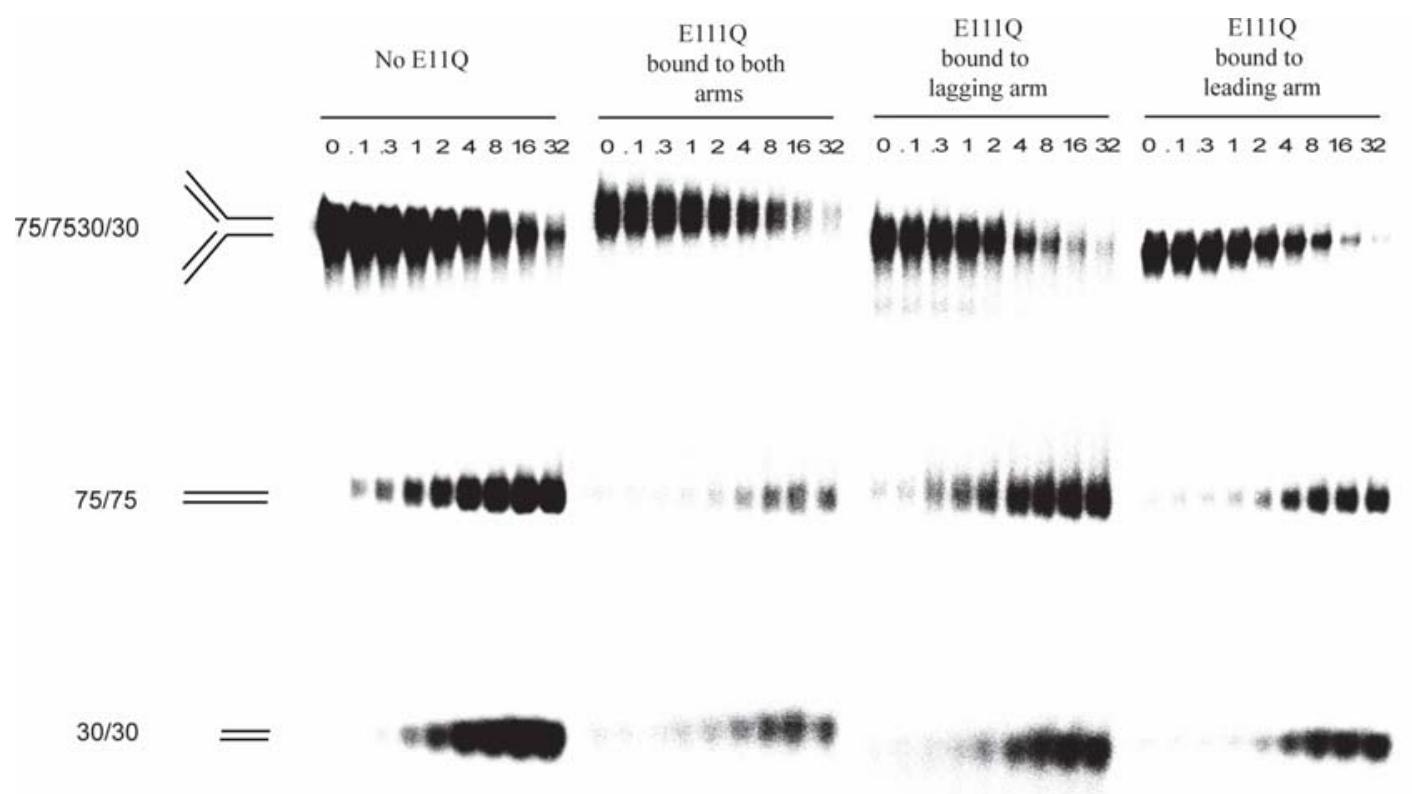

Figure 16. Fork reversal activity on modeled replication fork bound by EcoRI E111Q

A. Comparison of HLTF and BLM fork reversal activities on homologous fork bound by E111Q EcoRI protein on both the arms.

B. Comparison of HLTF fork reversal activities on homologous forks bound by E111Q EcoRI protein on one or both the arms 


\subsubsection{HLTF can regress a modeled replication fork bound by ssDNA binding protein}

It has been previously reported that the blockage of the replication machinery can lead to the uncoupling of leading and lagging strand synthesis, resulting in the generation of singlestranded (ss) DNA, which in turn will be occupied by Replication Protein A (RPA), a ssDNAbinding protein (Cordeiro-Stone M et al 1997; Svoboda DL \& Vos JM 1995). One would expect this RPA-ssDNA complex to be dissociated prior to DNA remodeling for a successful damage bypass. Previous data indicated that some DNA helicases such as Srs2 and BLM have the ability to remove certain proteins bound to ssDNA, which can be mechanistically explained by their ssDNA translocase activity (Colavito S et al 2010; Krejci L et al 2003). However, with a similar mechanism one can not expect ssDNA-bound protein removal by a dsDNA translocase such as HLTF, which is able to translocate on dsDNA but not on ssDNA. To model this situation we generated a 15 nucleotide long ssDNA gap region in the leading strand of fork DNA (Figure 17 A), where RPA or E.coli SSB was successfully bound, as shown by gel shift experiments (Figure 17 B \& C). Fork reversal assay revealed that HLTF can successfully regress these ssDNA binding protein-covered forks (Figure 18 A). RPA and E coli SSB covered fork DNAs were processed with similar efficiency, ruling out a role for a potential interaction between RPA and HLTF in this activity. RPA or SSB displacement can be explained by the dsDNA translocase activity of HLTF, assuming that during fork reversal HLTF translocates on the parental duplex DNA, when it concertedly unwinds the arms of the fork and zips the parental strands and the nascent strands and, coordinately with this process, removes the proteins encountered. Altogether, these fork reversal assays on protein bound substrates reveal the fact that HLTF can indeed remove ssDNA-binding proteins from DNA, and this removal is coordinated with its replication fork remodeling activity. 
A.

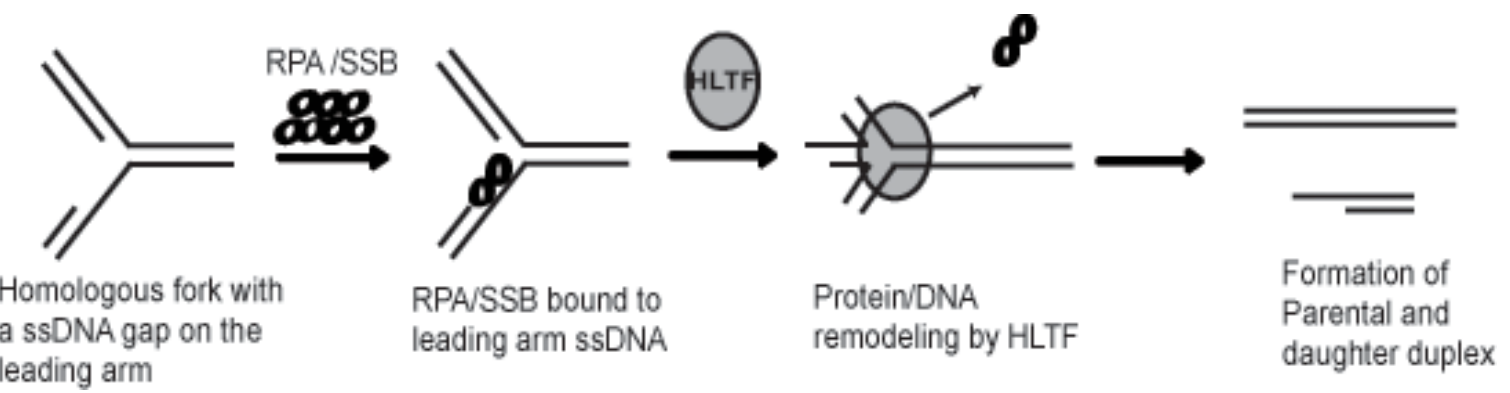

B.

Concentration
of RPA (nM)
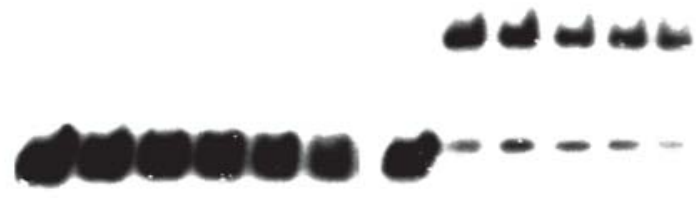

Fork without gap Fork with gap

C.

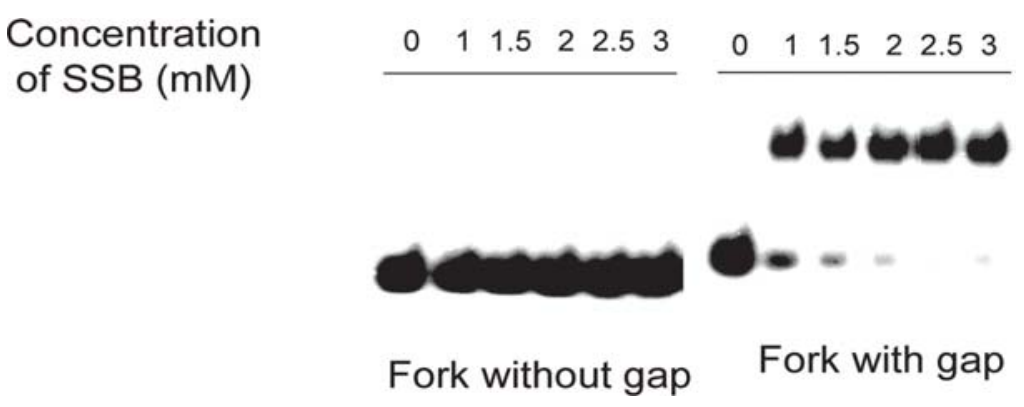

Figure 17. Specific binding of RPA and SSB to ssDNA gap in the modeled fork

A. Schematic representation of a possible mechanism through which HLTF can coordinately remodel a model replication fork bound by ssDNA binding proteins.

B. Gel retardation assay showing sequence-specific binding and formation of stable DNA-protein complex by RPA on oligo based fork like structures. Increasing amount of RPA was incubated with homologous fork containing a 15nt ssDNA gap on the leading arm.

C. Similar to panel B. Instead of RPA SSB is incubated with homologous fork containing a 15nt ssDNA gap on the leading arm 
A.

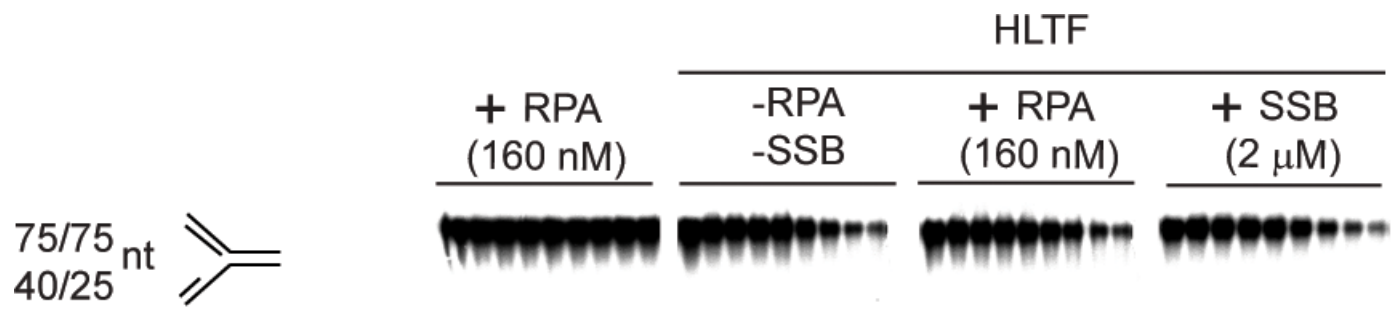

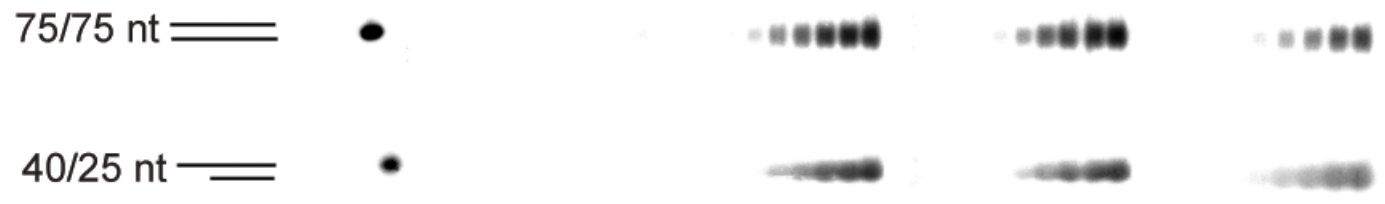

Time
$(\mathrm{min})$$\quad \frac{0.1 .312481632}{\mathrm{I}} \frac{0.1 .312481632}{\mathrm{II}} \frac{0.1 .312481632}{\mathrm{III}} \frac{0.1 .312481632}{\mathrm{IV}}$

B.

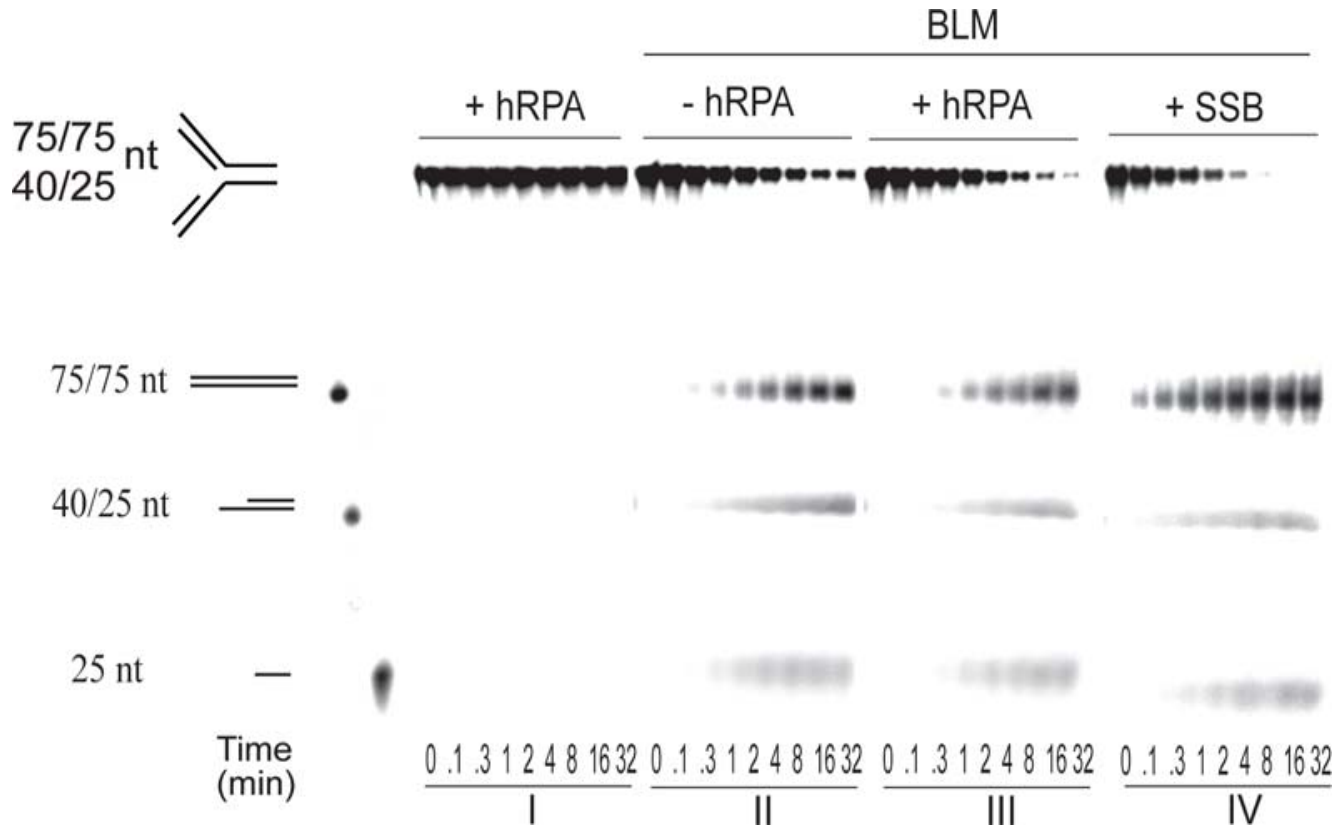

Figure 18. Fork reversal activity of HLTF and BLM on modeled replication fork bound by RPA or SSB

A. .HLTF fork reversal activities on homologous fork containing a ssDNA $15 \mathrm{nt}$ gap on the leading arm. ssDNA region was bound either by RPA or SSB.

B. Similar to panel A, but fork reversal activity was carried with BLM 


\subsubsection{HLTF can dislodge the PCNA, RFC \& RPA complex from DNA replication fork}

The above results confirm that HLTF can remodel ssDNA- as well as dsDNA-binding proteins on stalled replication fork-like DNA structures. However, the proteins tested were far from the nature and complexity of the proteins which can be found at the stalled replication fork in vivo. To provide further evidence that HLTF can indeed remodel various proteins expected to be present at a stalled replication fork, HLTF was examined if it can overcome the inhibitory effect of the complex composed by the replicative polymerase clamp PCNA and the clamp loader RFC proteins along with single strand binding protein RPA bound to a model replication fork substrate.

PCNA, RFC and RPA were bound to a substrate containing a 15 nucleotide long ssDNA region in the leading strand of fork DNA (Figure 19 A). In control experiments these DNA binding proteins completely inhibited fork reversal by BLM helicase (Fig.19 B). Importantly, however, HLTF was able to remodel the fork DNA substrate bound by these protein factors of the replication machinery. This activity was similar to what was seen with E. coli E111Q, where HLTF actively removed the protein from DNA and regressed oligo-based fork-like structures. This confirms that HLTF can indeed displace proteins present at the stalled replication fork, and this activity can be coordinated with its fork remodeling activity. Hence these results indicate that, along with its DNA remodeling activity, HLTF also has a general protein remodeling activity, and the two together provide the ability for HLTF to process a protein-covered stalled replication fork. 
A.

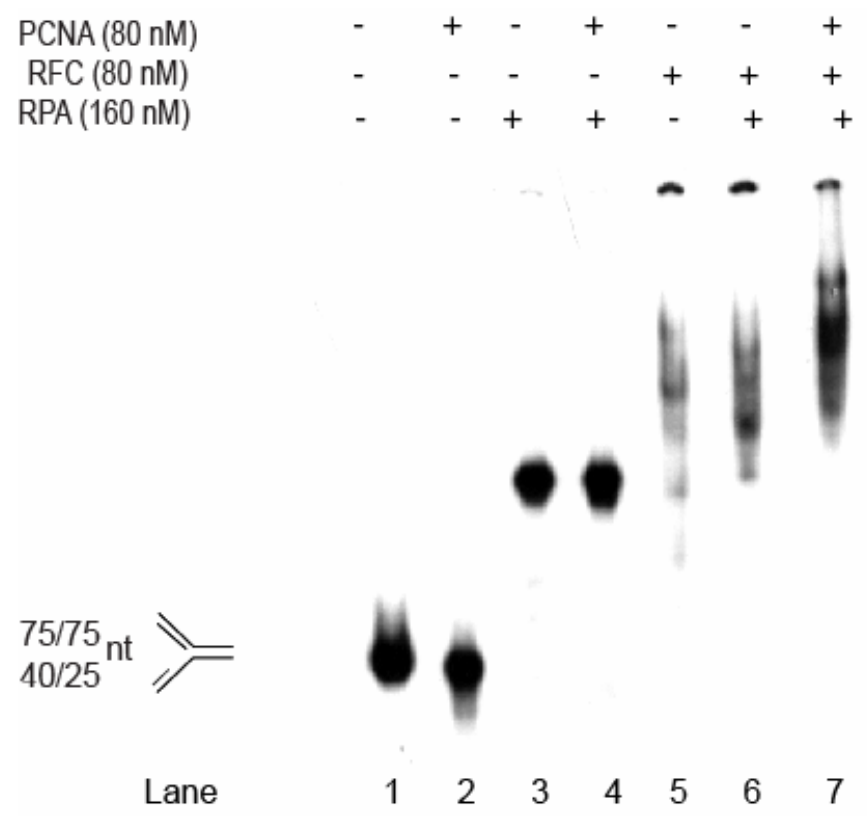

B.

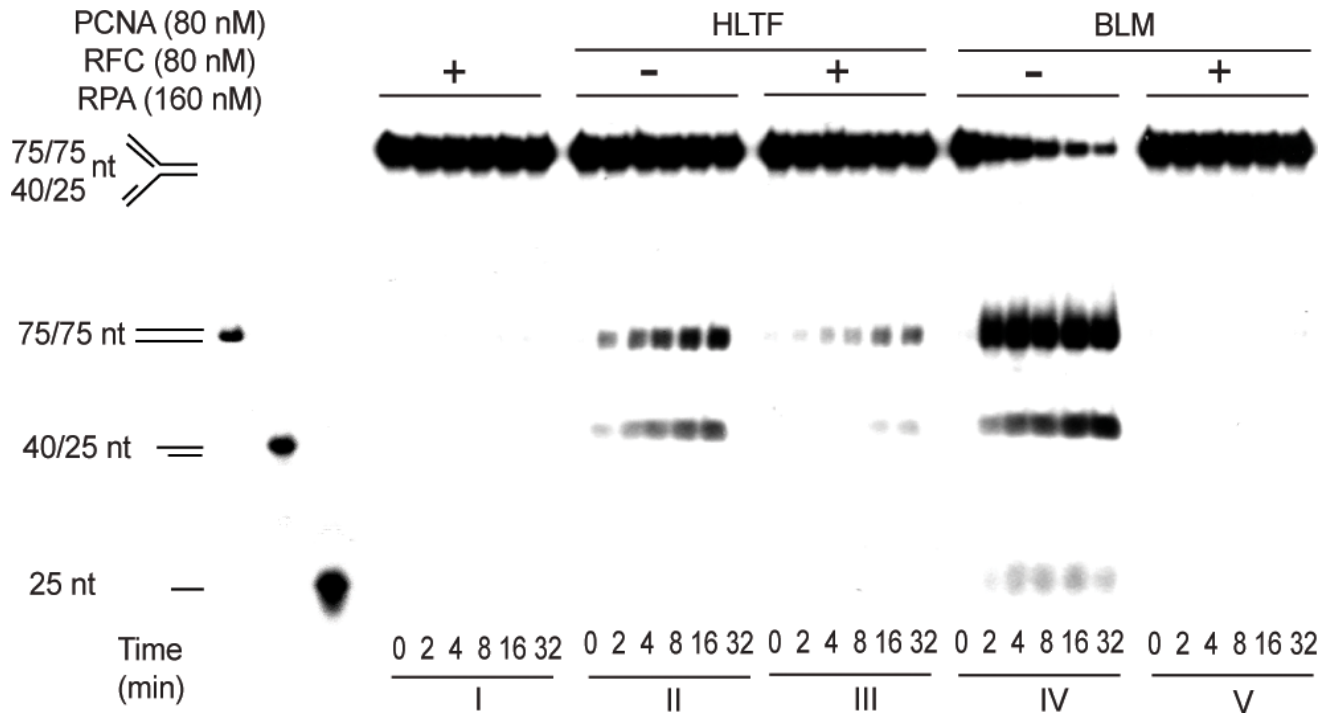

Figure 19. Fork reversal activity of HLTF on gapped replication fork like structures bound by replicative proteins PCNA, RFC and RPA

A. Gel retardation assays for confirming the binding of RPA, PCNA and RFC to a homologous fork containing a 15-nt gap on its leading arm.

B. Comparison of HLTF and BLM fork reversal activities on PCNA, RFC and RPA bound replication like structures. 


\subsection{Protein displacement activity of HLTF}

The ability of HLTF to regress a model replication fork in spite of fork being covered by proteins suggested that HLTF is able to actively remodel these proteins. To confirm this further, an experimental system was set up in which the actual displacement of E111Q EcoRI protein molecules from the fork can be monitored. As shown in Figure 20 A, biotin-tagged model forks containing an E111Q EcoRI protein bound to its binding site on one of the arms were immobilized on NeutrAvidin beads. Next, the fork regression assay was carried out on the beads by HLTF, where E111Q EcoRI proteins can become displaced into the supernatant. Finally, the supernatant was examined for the presence of E111Q EcoRI by trapping with a labelled duplex DNA containing an EcoRI binding site. Thus, the actual displacement can be monitored by the appearance of E111Q EcoRI-bound trap DNA in gel mobility shift experiments (Figure 20 B). It was found that upon HLTF-dependent DNA remodeling E111Q EcoRI protein molecules were released into the supernatant. Removal of bound E111Q EcoRI protein from the fork DNA was observed only with wild-type HLTF but was absent in mutant (DE557, 558AA) HLTF lacking ATPase/dsDNA translocase activity (Figuer $20 \mathrm{~B}$, compare lanes 4 and 6). Thus, this result not only provides evidence for HLTF's ability to remove dsDNA-binding proteins from the replication fork-like DNA structures but also confirms that this is an active process depending on HLTF's ATPase activity.

However, it was not clear whether the displacement of the dsDNA-binding protein is due to HLTF fork regression activity or is solely dependent on its dsDNA translocase activity. To answer this question, instead of a modeled fork, a 75/30-mer partial duplex DNA resembling only one arm of the previously used replication fork with an EcoRI binding site was bound to NeutrAvidin beads. This experiment revealed that HLTF can indeed displace a protein from a duplex DNA, and this displacement was only observed with the wild-type HLTF protein but not when the DE557, 558AA HLTF ATPase mutant was used (Figure $20 \mathrm{C}$ compare lane 5-6 with 89). These results provide evidence that HLTF, along with its ubiquitin ligase and fork regression activity, also has a protein remodeling activity. 
A.

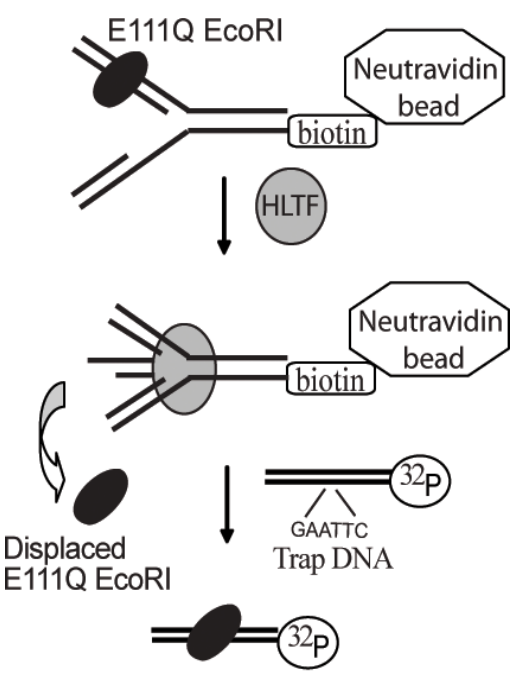

Trapped E111Q EcoRI protein
B.

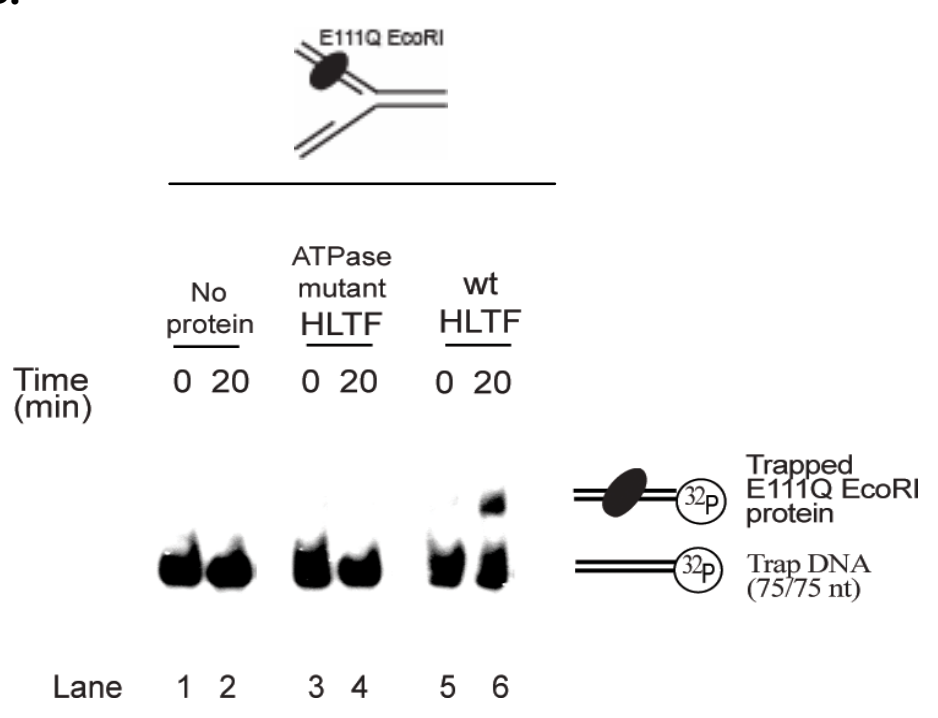

C.

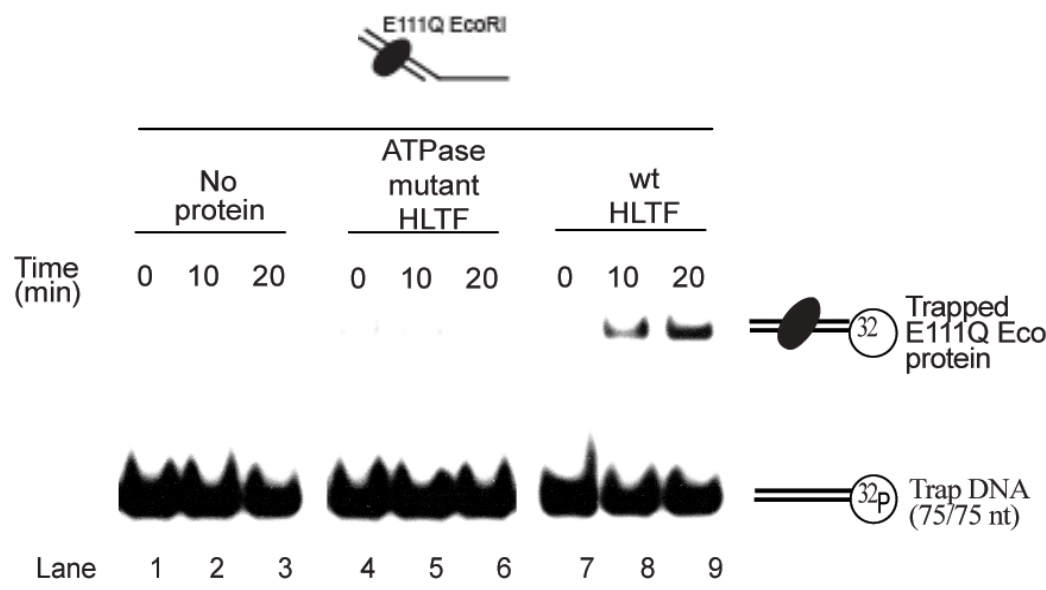

\section{Figure 20. Evidence for dsDNA binding protein disposal from DNA by HLTF}

A. Experimental setup to prove the actual displacement of dsDNA-binding protein during fork reversal. A homologous fork with a single EcoRI binding site is bound to NeutrAvidin beads through its biotin tag, and the E111Q EcoRI displaced from the fork is trapped by a 75-mer labeled duplex containing a single EcoRI site. The trap DNA is subjected to gel retardation assay to confirm the binding of E111Q EcoRI.

B. Gel retardation assay showing trapped E111Q EcoRI displaced from a modeled fork. Lane 1-2 no protein control; 3-4 HLTF ATPase mutant; 5-6 HLTF wild type protein. Samples were collected after 0 and 20 minutes for each protein sample and incubated with duplex trap DNA prior to gel retardation assay.

C. Similar assay like in panel B, except that instead of a modeled fork a 75/30-mer partial duplex DNA was used. Lane 1-3 no protein control; 4-6 HLTF ATPase mutant; 7-9 HLTF wild type protein. Samples were collected at 0,10 and 20 minutes for each protein sample and incubated with duplex trap DNA prior to gel retardation assay. 


\subsection{Conclusions from protein bound model forks}

Experiments with protein-bound fork revealed that HLTF can regress a fork even in the presence of wide varieties of proteins including ssDNA and dsDNA binding proteins. HLTF also could overcome the inhibitory effects of PCNA, RAFC and RPA, which are obviously present at the replication fork (Figure 21). However this was not the scenario with BLM, its fork regression activity was inhibited by the proteins mentioned above. So BLM or in that case any canonical helicase to regress a fork, proteins present at the replication fork has to be removed or displaced by an unknown mechanism.

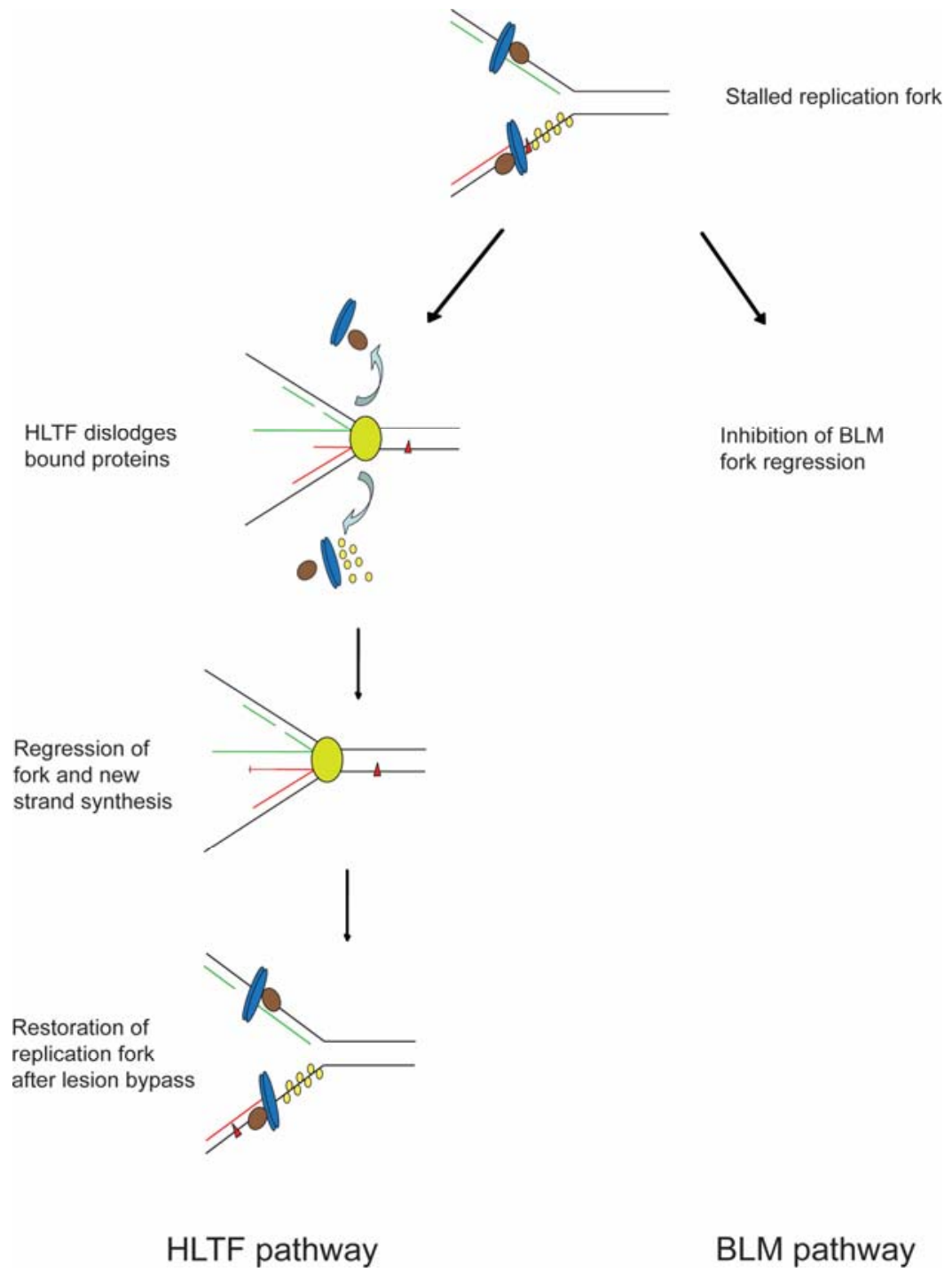

Figure 21. Differential fork regression activity of HLTF and BLM on protein bound substrates

BLM activity is completely inhibited in the presence of DNA binding proteins, However HLTF can dispose proteins to accomplish fork regression. 


\section{Discussion}

Previously it has been shown that HLTF and its yeast homolog, Rad5, have an ATPdependent dsDNA translocase activity enabling them to carry out replication fork reversal by concertedly unwinding the leading and lagging strand arms of the fork and then annealing together the nascent strands and the parental strands (Blastyak A et al 2007, Blastyak A et al 2010). This finding provided the first biochemical evidence for the capability of HLTF and Rad5 to facilitate error-free damage bypass by switching the template from the damaged leading strand to the newly synthesized undamaged nascent strand of the lagging arm. In addition to Rad5 and HLTF, the number of enzymes with proved fork reversal activity is continuously growing (Driscoll R and Cimprich KA (2009); Ralf C et al 2006; Collis SJ and Boulton SJ (2010); Kanagaraj $\mathrm{R}$ et al 2006; Machwe A et al 2006), which raises the possibility that many parallel pathways might exist for fork reversal and template switching. However, it has not been examined what happens to the huge protein complex present at the stalled replication fork, collectively referred to as replication machinery. It is evident that this complex or at least its particular elements have to be displaced from the fork for rescue mechanisms such as template switching to occur smoothly. For example, one can assume that PCNA would inhibit fork reversal since it encircles the DNA duplex, thereby preventing the separation of the nascent strand from the damaged template strand. For this obvious problem, however, no solution has been proposed, mainly because previous fork reversal assays were carried out using naked oligonucleotide- or plasmid-based fork DNA substrates. Possible hypotheses involve either removing particular proteins from the stalled fork by some unknown remodeling factor, or in situ degradation of these proteins.

Evidence for the first scenario is provided in this work and we also show for the first time that HLTF has a novel protein remodeling activity. This activity was recognized by investigating various ssDNA- or dsDNA-binding protein-covered modeled replication fork structures and asking if bound proteins have any inhibitory effects on fork reversal by HLTF and BLM that belong to the Swi2/Snf2 and RecQ family, respectively (Blastyak A et al 2010; Ralf C et al 2006). To our surprise, neither human replication proteins such as RFC and PCNA nor E.coli EcoRI protein, used as a site specific dsDNA-binding model protein, posed a big challenge for 
HLTF fork reversal activity, whereas they completely inhibited BLM helicase-dependent fork reversal. These experiments suggested that HLTF has a general protein remodeling activity, which can relocate DNA-bound proteins or might completely break off DNA-protein interaction. Supporting the second assumption, using NeutrAvidine bead-bound biotin-DNA substrates we managed to show that HLTF is indeed able to disrupt DNA-protein interactions as revealed by the appearance of displaced proteins relocated from the solid bead-DNA-protein fraction into the supernatant. Thus we suggest that on a protein-bound stalled replication fork, HLTF can not only facilitate a mere DNA-protein structural readjustment such as forcing the backtrack of the PCNA ring but is also able to remove inhibitory proteins from DNA and that both of these mechanisms might play a role in productive protein exchange and damage bypass.

As shown on a schematic model in Figure 22, I propose that HLTF has a protein cleansing function at stalled replication forks which is a prerequisite for successful fork remodeling leading finally to replication through the lesion. I hypothesize that remodeling proteins at the stalled replication fork and fork reversal can provide an opportunity either for a DNA polymerase to extend the originally blocked 3' DNA end using the newly synthesized sister strand as a template, or for excision repair to remove the lesion, or for recombination mediated replication to restart after cleavage of the reversed fork. It would be interesting to examine if HLTF protein displacement/DNA remodeling activity can operate on other structures, e.g. on D-loop intermediates of synthesis-dependent strand annealing mechanism, which has also been proposed to function in filling in ssDNA gaps that are left behind during replication (Torres-Ramos CA et al 2002). 


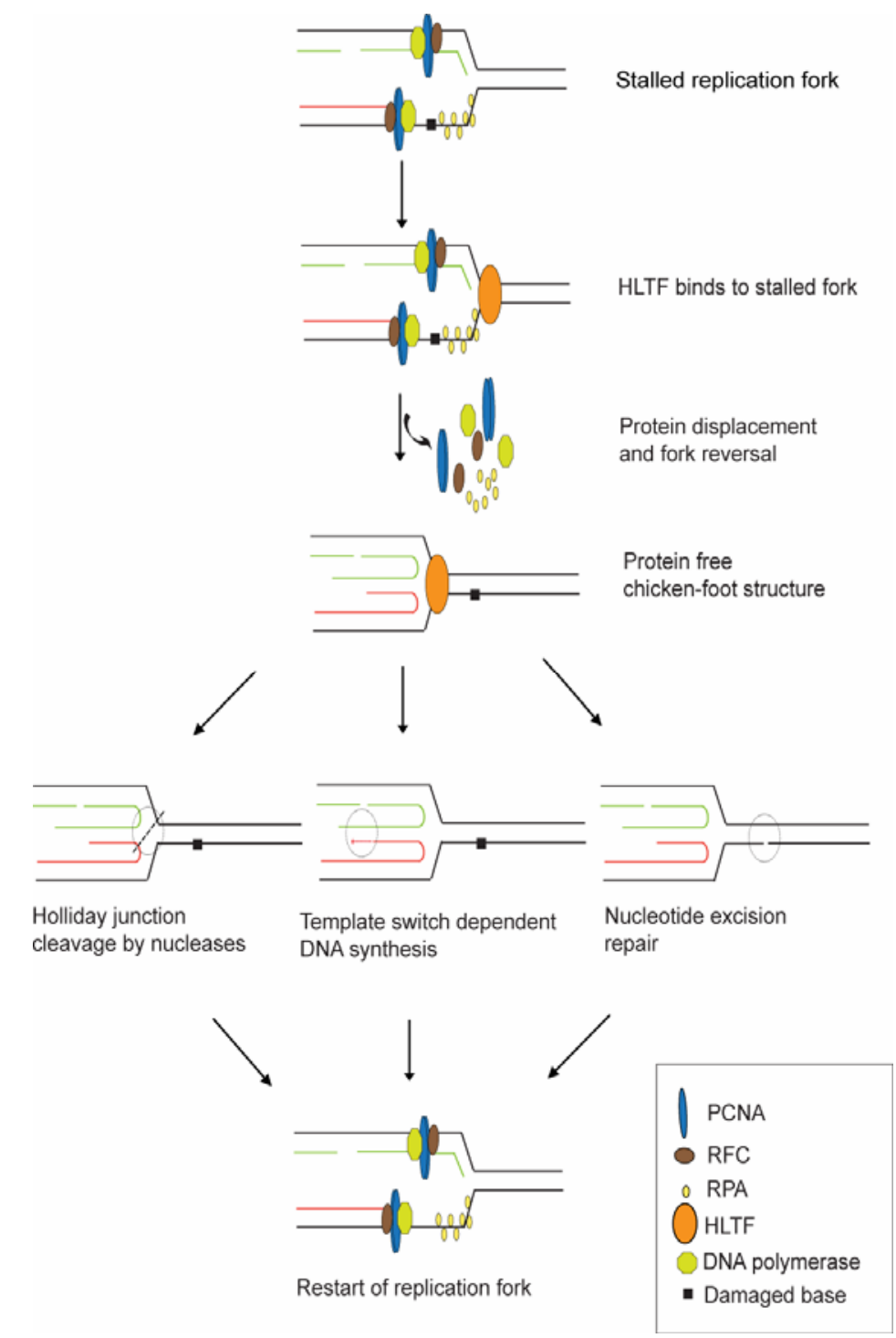

Figure 22. Proposed model for the role of HLTF in remodeling protein-covered stalled replication forks.

A stalled replication fork at an unrepaired DNA lesion has to undergo severe remodeling such that it can clear up most of its protein content, allowing other DNA repair machinery to get access to the DNA. We suggest that one such mechanism through which a fork can clear up its protein content can be facilitated by HLTF. HLTF can have dual functions, since it can not only clear up the proteins but also can give rise to a four-way junction intermediate called "chicken foot". This four-way junction can then be used by other subsequent repair pathways like (I) Holliday junction resolvases, which can resolve a four-way junction through their nuclease activity, (II) Template switch dependent DNA synthesis, where a DNA polymerase extends the 3' OH end of the leading nascent strand by copying from the nascent lagging strand, (III) Nucleotide excision repair pathway, where a short single-stranded DNA segment is removed creating a single-strand gap which is subsequently filled in by DNA polymerase using the undamaged strand as template. Once the lesion is repaired or bypassed, the stalled replication fork readopts its original structure and the progression of DNA replication is reestablished. 
For a number of DNA helicases such as yeast Srs2, human RECQ5 and BLM, displacement activity for the ssDNA-binding Rad51 protein has been reported (Colavita $\mathrm{S}$ et al 2010; Krejci L et al 2003; Hu Y et al 2007; Schwendener S et al 2010; Seong C et al 2009; Bugreev DV et al 2007). The specificity of these enzymes is ensured by their physical interaction with Rad51, and their mechanism can be explained by their ssDNA translocase activity by which they might break into the Rad51-ssDNA interface upon ATP hydrolysis dependent ssDNA translocation, resulting in breaking off the Rad51-ssDNA interaction. Being a dsDNA translocase, HLTF can be distinguished from these canonical DNA helicases, and I propose that the mechanism of protein remodeling by HLTF is more related to the action of Swi2/Snf2 chromatin remodeling enzymes.

In general, proteins in the Swi2/Snf2 family have been considered as chromatin remodeling enzymes for nucleosome displacement (Durr H et al 2006; Flaus A et al 2006). Mechanically, most of these enzymes can interact with dsDNA as well as with histones, usually present in their particular posttranslationally modified forms. By translocation on dsDNA they can induce local DNA distortion which contributes to nucleosome remodeling. Interestingly, the Swi2/Snf2-related Rdh54 and the Rad54 DNA branch migrating proteins exhibit not only nucleosome remodeling activity but can displace Rad51 as well (Bugreev DV et al 2010; Chi P et al 2006; Kwon Y et al 2007; Kwon Y et al 2008).

Also, from the Swi2/Snf2 family members Mot1 has been reported to have a nonnucleosomal protein remodeling activity. Mot1 is able to displace the TATA box-binding protein (TBP) from DNA, thereby providing a regulatory check for transcription. Mot1 does not detectably bind to DNA on its own, but the cooperative interaction between Mot1 and TBP can stabilize the ternary complex and, subsequently, the ATP hydrolysis dependent translocation of Mot1 on dsDNA into the TBP-DNA interface can result in TBP dissociation (Sprouse RO et al 2006). Whereas Mot1 is specific to TBP protein removal, which is ensured at least partly by its interaction with TBP, this study identifies HLTF as a more general protein remodeling enzyme. Support for this notion is provided by the ability of HLTF to remodel not only components of the replication machinery such as PCNA, RFC, and RPA with which its interaction cannot be ruled out, but also an E.coli dsDNA binding protein, namely EcoRI E111Q, with which its physical 
interaction is highly unlikely. Since the ATPase mutant HLTF is impaired in protein remodeling, we suggest that it is the local twisting and bending of DNA induced by ATP hydrolysis dependent HLTF translocation on dsDNA that constitutes the main force for breaking up proteinDNA interactions.

The discovered coordinated protein displacing/DNA remodeling activity of HLTF further extends the repertoire of the enzymatic capabilities of the intensively examined Swi2/Snf2 protein family and raises the question whether other members also exhibit similar activities. Thus, it would be interesting to test other Swi2/Snf2 proteins such as the Rad54, HARP, and FANCM fork reversal enzymes for general protein remodeling activity on various DNA structures such as stalled replication fork. Finally, since in a high percentage of various cancers, for example over $40 \%$ in colon cancers, HLTF expression is silenced or various Swi2/Snf2 domain deletion mutant HLTF proteins are expressed (Debauve G et al 2007; Moinova HR et al 2002), I suggest that the described coordinated protein displacing and DNA remodeling activity of HLTF is important to provide genome stability. 


\section{Summary of findings}

Some of the important findings obtained during the current thesis work are listed below.

I. HLTF and BLM although considered as a fork reversal enzymes, follow different mechanisms to rescue a stalled replication fork. HLTF functions as a classical fork regressing enzyme, where fork reversal goes through a 4 way junction called "Chicken-foot" structure. BLM on the other hand dissolves a fork instead of reversing it and this activity requires two separate enzymatic activities, a helicase and a strand annealing activity.

II. HLTF can displace several ssDNA and dsDNA binding proteins from the replication fork. This activity was not related to protein-protein interaction ability of HLTF with the displaced protein. This point was proved by using bacterial proteins such as E111Q EcoRI and SSB. However BLM was unable to dissolve a replication fork in the presence of these proteins.

III. One of the important findings of this work was to show how proteins such as PCNA, RFC and RPA belonging to the replication machinery are displaced/ removed from the site during the course of fork regression activity. HLTF was successful in regressing modeled fork containing the above mentioned proteins, where BLM was completely inefficient.

IV. This is the first evidence where protein removal activity of HLTF is reported and this protein disposable activity can be associated with its DNA translocating activity. 


\section{References:}

1. Aguilera A, Gómez-González B (2008) Genome instability: a mechanistic view of its causes and consequences. Nat Rev Genet; 9(3):204-17.

2. $\mathrm{Au} \mathrm{KG}$, Welsh K, Modrich P (1992) Initiation of methyl-directed mismatch repair. J Biol Chem; 267(17):12142-8.

3. Bachrati CZ, Hickson ID (2003) RecQ helicases: suppressors of tumorigenesis and premature aging. Biochem J; 374(Pt 3):577-606

4. Bachrati CZ, Hickson ID (2008) RecQ helicases: guardian angels of the DNA replication fork. Chromosoma; 117(3):219-33.

5. Bailly V, Lamb J, Sung P, Prakash S, Prakash L. (1994) Specific complex formation between yeast RAD6 and RAD18 proteins: a potential mechanism for targeting RAD6 ubiquitin-conjugating activity to DNA damage sites. Genes Dev. 1;8(7):811-20

6. Bailly V, Prakash S, Prakash L (1997) Domains required for dimerization of yeast Rad6 ubiquitin-conjugating enzyme and Rad18 DNA binding protein. Mol Cell Biol; 17(8):4536-43.

7. Barnes DE, Lindahl T (2004) Repair and genetic consequences of endogenous DNA base damage in mammalian cells. Annu Rev Genet; 38:445-76.

8. Barzilay G, Hickson ID (1995) Structure and function of apurinic/apyrimidinic endonucleases.Bioessays; 17(8):713-9.

9. Bernstein DA, Keck JL (2003) Domain mapping of Escherichia coli RecQ defines the roles of conserved $\mathrm{N}$ - and C-terminal regions in the RecQ family. Nucleic Acids Res; 31(11):2778-85.

10. Bernstein DA, Keck JL (2005) Conferring substrate specificity to DNA helicases: role of the RecQ HRDC domain. Structure; 13(8):1173-82.

11. Bernstein DA, Zittel MC, Keck JL (2003) High-resolution structure of the E.coli RecQ helicase catalytic core. EMBO J; 22(19):4910-21. 
12. BF Cheok CF, Bachrati CZ, Chan KL, Ralf C, Wu L, Hickson ID (2005) Roles of the Bloom's syndrome helicase in the maintenance of genome stability. Biochem Soc Trans; 33(Pt 6):1456-9.

13. Blastyák A, Pintér L, Unk I, Prakash L, Prakash S, Haracska L (2007) Yeast Rad5 protein required for postreplication repair has a DNA helicase activity specific for replication fork regression. Mol Cell; 28(1):167-75.

14. Boiteux S, Guillet M. (2004) Abasic sites in DNA: repair and biological consequences in Saccharomyces cerevisiae. DNA Repair (Amst); 3(1):1-12.

15. Broomfield S, Chow BL, Xiao W (1998) MMS2, encoding a ubiquitin-conjugatingenzyme-like protein, is a member of the yeast error-free postreplication repair pathway. Proc Natl Acad Sci U S A; 95(10):5678-83.

16. Brosh RM Jr, von Kobbe C, Sommers JA, Karmakar P, Opresko PL, Piotrowski J, Dianova I, Dianov GL, Bohr VA (2001) Werner syndrome protein interacts with human flap endonuclease 1 and stimulates its cleavage activity. EMBO J; 20(20):5791-801.

17. Brusky J, Zhu Y, Xiao W (2000) UBC13, a DNA-damage-inducible gene, is a member of the error-free postreplication repair pathway in Saccharomyces cerevisiae. Curr Genet; 37(3):168-74.

18. Bugreev DV, Hanaoka F, Mazin AV (2007) Rad54 dissociates homologous recombination intermediates by branch migration. Nat Struct Mol Biol;14(8):746-53.

19. Capouillez A, Debauve G, Decaestecker C, Filleul O, Chevalier D, Mortuaire G, Coppée F, Leroy X, Belayew A, Saussez S (2009) The helicase-like transcription factor is a strong predictor of recurrence in hypopharyngeal but not in laryngeal squamous cell carcinomas Histopathology; 55(1):77-90.

20. Capouillez A, Decaestecker C, Filleul O, Chevalier D, Coppée F, Leroy X, Belayew A, Saussez S (2008) Helicase-like transcription factor exhibits increased expression and altered intracellular distribution during tumor progression in hypopharyngeal and laryngeal squamous cell carcinomas. Virchows Arch; 453(5):491-9. 
21. Carles-Kinch K, George JW, Kreuzer KN (1997) Bacteriophage T4 UvsW protein is a helicase involved in recombination, repair and the regulation of DNA replication origins. EMBO J; 16(13):4142-51.

22. Carlile CM, Pickart CM, Matunis MJ, Cohen RE (2009) Synthesis of free and proliferating cell nuclear antigen-bound polyubiquitin chains by the RING E3 ubiquitin ligase Rad5. J Biol Chem; 284(43):29326-34.

23. Chaganti RS, Schonberg S, German J (1974) A manyfold increase in sister chromatid exchanges in Bloom's syndrome lymphocytes. Proc Natl Acad Sci U S A; 71(11):450812.

24. Cheng KC, Cahill DS, Kasai H, Nishimura S, Loeb LA (1992) 8-Hydroxyguanine, an abundant form of oxidative DNA damage, causes G----T and A----C substitutions. J Biol Chem; 267(1):166-72.

25. Cheok CF, Bachrati CZ, Chan KL, Ralf C, Wu L, Hickson ID (2005) Roles of the Bloom's syndrome helicase in the maintenance of genome stability. Biochem Soc Trans; 33(Pt 6):1456-9.

26. Cheok CF, Wu L, Garcia PL, Janscak P, Hickson ID (2005) The Bloom's syndrome helicase promotes the annealing of complementary single-stranded DNA. Nucleic Acids Res; 33(12):3932-41.

27. Cobb JA, Bjergbaek L (2006) RecQ helicases: lessons from model organisms. Nucleic Acids Res; 34(15):4106-14.

28. Colavito S, Prakash R, Sung P (2010) Promotion and regulation of homologous recombination by DNA helicases. Methods 51(3):329-335

29. Courcelle J, Donaldson JR, Chow KH, Courcelle CT (2003) DNA damage-induced replication fork regression and processing in Escherichia coli. Science; 299(5609):10647.

30. Courcelle J, Hanawalt PC (2003) RecA-dependent recovery of arrested DNA replication forks. Annu Rev Genet; 37:611-46.

31. Cox MM (2001) Recombinational DNA repair of damaged replication forks in Escherichia coli: questions. Annu Rev Genet; 35:53-82. 
32. Defossez PA, Prusty R, Kaeberlein M, Lin SJ, Ferrigno P, Silver PA, Keil RL, Guarente L (1999) Elimination of replication block protein Fob1 extends the life span of yeast mother cells. Mol Cell; 3(4):447-55.

33. Ding H, Descheemaeker K, Marynen P, Nelles L, Carvalho T, Carmo-Fonseca M, Collen D, Belayew A (1996) Characterization of a helicase-like transcription factor involved in the expression of the human plasminogen activator inhibitor-1 gene. DNA Cell Biol; 15(6):429-42.

34. Eggleston AK, Mitchell AH, West SC (1997) In vitro reconstitution of the late steps of genetic recombination in E. coli. Cell; 89(4):607-17.

35. Ferguson DO, Sekiguchi JM, Chang S, Frank KM, Gao Y, DePinho RA, Alt FW (2000) The nonhomologous end-joining pathway of DNA repair is required for genomic stability and the suppression of translocations. Proc Natl Acad Sci U S A; 97(12):6630-3.

36. Flaus A, Martin DM, Barton GJ, Owen-Hughes T (2006) Identification of multiple distinct Snf2 subfamilies with conserved structural motifs. Nucleic Acids Res; 34(10):2887-905.

37. Flores-Rozas H, Clark D, Kolodner RD (2000) Proliferating cell nuclear antigen and Msh2p-Msh6p interact to form an active mispair recognition complex. Nat Genet; 26(3):375-8.

38. Fortini P, Pascucci B, Parlanti E, D'Errico M, Simonelli V, Dogliotti E (2003), The base excision repair: mechanisms and its relevance for cancer susceptibility. Biochimie; 85(11):1053-71.

39. Friedberg EC (2003) DNA damage and repair. Nature; 421(6921):436-40.

40. Friedberg EC (2005) Suffering in silence: the tolerance of DNA damage. Nat Rev Mol Cell Biol; 6(12):943-53.

41. Friedberg EC, Lehmann AR, Fuchs RP (2005) Trading places: how do DNA polymerases switch during translesion DNA synthesis? Mol cell; 27; 18(5):499-505.

42. Fujiwara Y, Tatsumi M (1976) Replicative bypass repair of ultraviolet damage to DNA of mammalian cells: caffeine sensitive and caffeine resistant mechanisms. Mutat Res; 37(1):91-110. 
43. Fukuoka T, Hibi K, Nakao A (2006) Aberrant methylation is frequently observed in advanced esophageal squamous cell carcinoma. Anticancer Res; 26(5A):3333-5.

44. Garg P, Burgers PM (2005) Ubiquitinated proliferating cell nuclear antigen activates translesion DNA polymerases eta and REV1. Proc Natl Acad Sci U S A. 2005 Dec 20;102(51):18361-6.

45. Gari K, Décaillet C, Delannoy M, Wu L, Constantinou A (2008) Remodeling of DNA replication structures by the branch point translocase FANCM. Proc Natl Acad Sci U S A; 105(42):16107-12.

46. Gari K, Décaillet C, Stasiak AZ, Stasiak A, Constantinou A (2008) The Fanconi anemia protein FANCM can promote branch migration of Hollida junctions and replication forks. Mol Cell; 29(1):141-8.

47. Grompone G, Ehrlich D, Michel B (2004) Cells defective for replication restart undergo replication fork reversal. EMBO Rep; 5(6):607-12.

48. Hamdan SM, Richardson CC (2009) Motors, switches, and contacts in the replisome. Annu Rev Biochem. 78:205-43.

49. Haracska L, Johnson RE, Unk I, Phillips B, Hurwitz J, Prakash L, Prakash S (2001) Physical and functional interactions of human DNA polymerase eta with PCNA. Mol Cell Biol; 21(21):7199-206.

50. Haracska L, Johnson RE, Unk I, Phillips BB, Hurwitz J, Prakash L, Prakash S (2001) Targeting of human DNA polymerase iota to the replication machinery via interaction with PCNA. Proc Natl Acad Sci U S A; 98(25):14256-61.

51. Haracska L, Prakash L, Prakash S (2002) Role of human DNA polymerase kappa as an extender in translesion synthesis. Proc Natl Acad Sci U S A; 99(25):

52. Haracska L, Torres-Ramos CA, Johnson RE, Prakash S, Prakash L(2004) Opposing effects of ubiquitin conjugation and SUMO modification of PCNA on replicational bypass of DNA lesions in Saccharomyces cerevisiae. Mol Cell Biol; 24(10):4267-74.

53. Haracska L, Unk I, Prakash L, Prakash S (2006) Ubiquitylation of yeast proliferating cell nuclear antigen and its implications for translesion DNA synthesis. Proc Natl Acad Sci U S A;103(17):6477-82. 
54. Hargreaves D, Rice DW, Sedelnikova SE, Artymiuk PJ, Lloyd RG, Rafferty JB (1998) Crystal structure of E.coli RuvA with bound DNA Holliday junction at 6 A resolution. Nat Struct Biol; 5(6):441-6.

55. Harrigan JA, Bohr VA (2003) Human diseases deficient in RecQ helicases. Biochimie; 85(11):1185-93.

56. Hashimoto K, Tominaga Y, Nakabeppu Y, Moriya M (2004) Futile short-patch DNA base excision repair of adenine:8-oxoguanine mispair. Nucleic Acids Res; 32(19):5928-34.

57. Heyer WD (2004) Recombination: Holliday junction resolution and crossover formation. Curr Biol,14(2):R56-8.

58. Heyer WD, Li X, Rolfsmeier M, Zhang XP (2006) Rad54: the Swiss Army knife of homologous recombination? Nucleic Acids Res; 34(15):4115-25.

59. Hibi K, Nakayama H, Kanyama Y, Kodera Y, Ito K, Akiyama S, Nakao A (2003) Methylation pattern of HLTF gene in digestive tract cancers. Int J Cancer; 104(4):433-6.

60. Hickson ID (2003) RecQ helicases: caretakers of the genome. Nat Rev Cancer; 3(3):16978.

61. Hickson ID (2003) RecQ helicases: caretakers of the genome. Nat Rev Cancer; 3(3):16978.

62. Higgins NP, Kato K, Strauss B (1976) A model for replication repair in mammalian cells. J Mol Biol; 101(3):417-25.

63. Higuchi K, Katayama T, Iwai S, Hidaka M, Horiuchi T, Maki H (2003) Fate of DNA replication fork encountering a single DNA lesion during oriC plasmid DNA replication in vitro. Genes Cells; 8(5):437-49.

64. Hiom K, Tsaneva IR, West SC (1996) The directionality of RuvAB-mediated branch migration: in vitro studies with three-armed junctions. Genes Cells; 1(5):443-51.

65. Hochegger H, Takeda S (2006) Phenotypic analysis of cellular responses to DNA damage. Subcell Biochem; 40:313-25.

66. Hiom K, Tsaneva IR, West SC (1996) The directionality of RuvAB-mediated branch migration: in vitro studies with three-armed junctions. Genes Cells; 1(5):443-51. 
67. Hoege C, Pfander B, Moldovan GL, Pyrowolakis G, Jentsch S (2002) RAD6-dependent DNA repair is linked to modification of PCNA by ubiquitin and SUMO. Nature; 419(6903):135-41.

68. Hofmann RM, Pickart CM (1999) Noncanonical MMS2-encoded ubiquitin-conjugating enzyme functions in assembly of novel polyubiquitin chains for DNA repair. Cell; 96(5):645-53.

69. Holmquist GP (1998) Endogenous lesions, S-phase-independent spontaneous mutations, and evolutionary strategies for base excision repair, Mutat Res; 400(1-2):59-68.

70. Hoege C, Pfander B, Moldovan GL, Pyrowolakis G, Jentsch S (2002) RAD6-dependent DNA repair is linked to modification of PCNA by ubiquitin and SUMO. Nature; 419(6903):135-41.

71. Hotchkiss RD (1974) Models of genetic recombination. Annu Rev Microbiol; 28(0):44568.

72. Huttner D, Ulrich HD (2008) Cooperation of replication protein A with the ubiquitin ligase Rad18 in DNA damage bypass. Cell Cycle; 7(23):3629-33.

73. Iyer RR, Pluciennik A, Burdett V, Modrich PL (2006) DNA mismatch repair: functions and mechanisms. Chem Rev; 106(2):302-23.

74. Johnson RE, Prakash S, Prakash L. (1994) Yeast DNA repair protein RAD5 that promotes instability of simple repetitive sequences is a DNA-dependent ATPase. J Biol Chem; 269(45):28259-62.

75. Jackson SP (2002) Sensing and repairing DNA double-strand breaks. Carcinogenesis; 23(5):687-96.

76. Jentsch S, McGrath JP, Varshavsky A (1987)The yeast DNA repair gene RAD6 encodes a ubiquitin-conjugating enzyme. Nature; 329(6135):131-4.

77. Johnson RE, Henderson ST, Petes TD, Prakash S, Bankmann M, Prakash L (1992) Saccharomyces cerevisiae RAD5-encoded DNA repair protein contains DNA helicase and zinc-binding sequence motifs and affects the stability of simple repetitive sequences in the genome. Mol Cell Biol; 12(9):3807-18. 
78. Johnson RE, Washington MT, Haracska L, Prakash S, Prakash L (2000) Eukaryotic polymerases iota and zeta act sequentially to bypass DNA lesions. Nature; 406(6799):1015-9.

79. Johnson RE, Prakash S, Prakash L (1994) Yeast DNA repair protein RAD5 that promotes instability of simple repetitive sequences is a DNA-dependent ATPase. J Biol Chem; 269(45):28259-62.

80. Johnson RE, Prakash S, Prakash L (1999) Efficient bypass of a thymine-thymine dimer by yeast DNA polymerase, Poleta. Science; 283(5404):1001-4.

81. Johnson, R,C., and W.F. McNeill (1978) Electron microscopy of UV-induced postreplication repair of daughter strand gaps. p.95-99. In P.C. Hanawalt, E.C. Friedberg, and C.F. Fox (ed.), DNA Repair Mechanisms. Academic Press, Inc., New York, New York.

82. Kanagaraj R, Saydam N, Garcia PL, Zheng L, Janscak P (2006) Human RECQ5beta helicase promotes strand exchange on synthetic DNA structures resembling a stalled replication fork. Nucleic Acids Res; 34(18):5217-31.

83. Karanjawala ZE, Grawunder U, Hsieh CL, Lieber MR, (1999) The nonhomologous DNA end joining pathway is important for chromosome stability in primary fibroblasts. Curr Biol; 9(24):1501-4.

84. Karow JK, Constantinou A, Li JL, West SC, Hickson ID (2000)The Bloom's syndrome gene product promotes branch migration of holliday junctions.

85. Karow JK, Chakraverty RK, Hickson ID (1997) The Bloom's syndrome gene product is a 3'-5' DNA helicase. J Biol Chem; 272(49):30611-4.

86. Kerr ID, Sivakolundu S, Li Z, Buchsbaum JC, Knox LA, Kriwacki R, White SW (2007) Crystallographic and NMR analyses of UvsW and UvsW.1 from bacteriophage T4. J Biol Chem; 282(47):34392-400.

87. Kolodner R (1996) Biochemistry and genetics of eukaryotic mismatch repair. Genes Dev; 10(12):1433-42.

88. Krogh BO, Symington LS (2004) Recombination proteins in yeast. Annu Rev Genet; 38:233-71. 
89. Kunkel TA, Burgers PM (2008) Dividing the workload at a eukaryotic replication fork. Trends Cell Biol. 11:521-7.

90. Langston LD, O'Donnell M (2008) DNA polymerase delta is highly processive with proliferating cell nuclear antigen and undergoes collision release upon completing DNA. J Biol Chem. 283(43):29522-31.

91. Lawrence CW (1982) Mutagenesis in Saccharomyces cerevisiae. Adv Genet.1982; $21: 173-254$.

92. Lawrence CW, Maher VM (2001) Mutagenesis in eukaryotes dependent on DNA polymerase zeta and Rev1p. Philos Trans R Soc Lond B Biol Sci; 356(1405):41-6.

93. Lawrence CW, Maher VM (2001) Eukaryotic mutagenesis and translesion replication dependent on DNA polymerase zeta and Rev1 protein. Biochem Soc Trans; 29(Pt 2):18791.

94. Leung WK, Yu J, Bai AH, Chan MW, Chan KK, To KF, Chan FK, Ng EK, Chung SC, Sung JJ (2003)Inactivation of helicase-like transcription factor by promoter hypermethylation in human gastric cancer. Mol Carcinog; 37(2):91-7.

95. Lewis LK, Resnick MA (2000) Tying up loose ends: nonhomologous end-joining in Saccharomyces cerevisiae. Mutat Res; 451(1-2):71-89.

96. Li Z, Lu S, Hou G, Ma X, Sheng D, Ni J, Shen Y (2008) Hjm/Hel308A DNA helicase from Sulfolobus tokodaii promotes replication fork regression and interacts with Hjc endonuclease in vitro. J Bacteriol; 190(8):3006-17.

97. Lindahl T, Barnes DE (2000) Repair of endogenous DNA damage. Cold Spring Harb Symp Quant Biol ;65:127-33.

98. Lindahl, T (1993) Recovery of antediluvian DNA. Nature; 365(6448):700.

99. Liu Z, Macias MJ, Bottomley MJ, Stier G, Linge JP, Nilges M, Bork P, Sattler M. (1999)The three-dimensional structure of the HRDC domain and implications for the Werner and Bloom syndrome proteins. Structure; 7(12):1557-66.

100. Long DT, Kreuzer KN (2008) Regression supports two mechanisms of fork processing in phage T4. Proc Natl Acad Sci U S A. 2008 May 13;105(19):6852-7. 
101. Long DT, Kreuzer KN. (2009) Fork regression is an active helicase-driven pathway in bacteriophage T4. EMBO Rep; 10(4):394-9.

102. Longley MJ, Pierce AJ, Modrich P (1997) DNA polymerase delta is required for human mismatch repair in vitro. J Biol Chem; 272(16):10917-21.

103. Louarn JM, Louarn J, François V, Patte J (1991) Analysis and possible role of hyperrecombination in the termination region of the Escherichia coli chromosome. $\mathrm{J}$ Bacteriol; 173(16):5097-104.

104. Lusetti SL, Cox MM (2002) The bacterial RecA protein and the recombinational DNA repair of stalled replication forks. Annu Rev Biochem; 71:71-100.

105. Machwe A, Xiao L, Groden J, Orren DK (2006) The Werner and Bloom syndrome proteins catalyze regression of a model replication fork. Biochemistry;45(47):13939-46.

106. Machwe A, Lozada EM, Xiao L, Orren DK (2006) Competition between the DNA unwinding and strand pairing activities of the Werner and Bloom syndrome proteins. BMC Mol Biol; 7:1.

107. Machwe A, Xiao L, Groden J, Matson SW, Orren DK (2005) RecQ family members combine strand pairing and unwinding activities to catalyze strand exchange. J Biol Chem; 280(24):23397-407. Epub 2005 Apr 20.

108. Machwe A, Xiao L, Groden J, Orren DK (2006) The Werner and Bloom syndrome proteins catalyze regression of a model replication fork. Biochemistry; 45(47):13939-46.

109. Machwe A, Xiao L, Orren DK (2006) Length-dependent degradation of single-stranded 3' ends by the Werner syndrome protein (WRN): implications for spatial orientation and coordinated $3^{\prime}$ to 5 ' movement of its ATPase/helicase and exonuclease domains. BMC Mol Biol; 7:6.

110. Machwe A, Xiao L, Lloyd RG, Bolt E, Orren DK (2007) Replication fork regression in vitro by the Werner syndrome protein (WRN): holliday junction formation, the effect of leading arm structure and a potential role for WRN exonuclease activity. Nucleic Acids Res; 35(17):5729-47.

111. MacKay C, Toth R, Rouse J (2009) Biochemical characterisation of the SWI/SNF family member HLTF. Biochem Biophys Res Commun; 390(2):187-91. 
112. Mahajan MC, Weissman SM (2002) DNA-dependent adenosine triphosphatase (helicaselike transcription factor) activates beta-globin transcription in K562 cells. Blood; 99(1):348-56.

113. Mathew CG (2006) Fanconi anaemia genes and susceptibility to cancer. Oncogene; 25(43):5875-84.

114. McDonald JP, Levine AS, Woodgate R (1997) The Saccharomyces cerevisiae RAD30 gene, a homologue of Escherichia coli $\operatorname{dinB}$ and umuC, is DNA damage inducible and functions in a novel error-free postreplication repair mechanism. Genetics; 147(4):155768.

115. McGlynn P, Lloyd RG (2000) Modulation of RNA polymerase by (p)ppGpp reveals a RecG-dependent mechanism for replication fork progression. Cell; 101(1):35-45.

116. McGlynn P, Lloyd RG (2001) Rescue of stalled replication forks by RecG: simultaneous translocation on the leading and lagging strand templates supports an active DNA unwinding model of fork reversal and Holliday junction formation. Proc Natl Acad Sci U S A; 98(15):8227-34.

117. McGlynn P, Lloyd RG (2000) Modulation of RNA polymerase by (p)ppGpp reveals a RecG-dependent mechanism for replication fork progression. Cell; 101(1):35-45.

118. McGlynn P, Lloyd RG (2001) Action of RuvAB at replication fork structures. J Biol Chem; 276(45):41938-44.

119. McGlynn P, Lloyd RG (2002) Recombinational repair and restart of damaged replication forks. Nat Rev Mol Cell Biol; 3(11):859-70.

120. McGlynn P, Lloyd RG, Marians KJ (2001) Formation of Holliday junctions by regression of nascent DNA in intermediates containing stalled replication forks: RecG stimulates regression even when the DNA is negatively supercoiled. Proc Natl Acad Sci U S A; 98(15):8235-40.

121. McGlynn P, Lloyd RG (2002) Recombinational repair and restart of damaged replication forks. Nat Rev Mol Cell Biol; 3(11):859-70.

122. McGlynn P, Mahdi AA, Lloyd RG (2000) Characterisation of the catalytically active form of RecG helicase. Nucleic Acids Res; 28(12):2324-32. 
123. McInerney P, O'Donnell M (2004) Functional uncoupling of twin polymerases: mechanism of polymerase dissociation from a lagging-strand block. J Biol Chem; 279(20):21543-51.

124. Meetei AR, Medhurst AL, Ling C, Xue Y, Singh TR, Bier P, Steltenpool J, Stone S, Dokal I, Mathew CG, Hoatlin M, Joenje H, de Winter JP, Wang W (2005) A human ortholog of archaeal DNA repair protein Hef is defective in Fanconi anemia complementation group M. Nat Genet; 37(9):958-63.

125. Michel B, Boubakri H, Baharoglu Z, LeMasson M, Lestini R (2007) Recombination proteins and rescue of arrested replication forks. DNA Repair (Amst); 6(7):967-80.

126. Michel B, Ehrlich SD, Uzest M (1997) DNA double-strand breaks caused by replication arrest. EMBO J; 16(2):430-8.

127. Modrich P, Lahue R (1996) Mismatch repair in replication fidelity, genetic recombination, and cancer biology. Annu Rev Biochem; 65:101-33.

128. Moinova HR, Chen WD, Shen L, Smiraglia D, Olechnowicz J, Ravi L, Kasturi L, Myeroff L, Plass C, Parsons R, Minna J, Willson JK, Green SB, Issa JP, Markowitz SD (2002)HLTF gene silencing in human colon cancer. Proc Natl Acad Sci U S A; 99(7):4562-7.

129. Morozov V, Mushegian AR, Koonin EV, Bork P (1997) A putative nucleic acid-binding domain in Bloom's and Werner's syndrome helicases. Trends Biochem Sci; 22(11):417-8.

130. Motegi A, Liaw HJ, Lee KY, Roest HP, Maas A, Wu X, Moinova H, Markowitz SD, Ding H, Hoeijmakers JH, Myung K (2008) Polyubiquitination of proliferating cell nuclear antigen by HLTF and SHPRH prevents genomic instability from stalled replication forks. Proc Natl Acad Sci U S A; 105(34):12411-6.

131. Motegi A, Sood R, Moinova H, Markowitz SD, Liu PP, Myung K (2006) Human SHPRH suppresses genomic instability through proliferating cell nuclear antigen polyubiquitination. J Cell Biol; 175(5):703-8.

132. Motegi A, Liaw HJ, Lee KY, Roest HP, Maas A, Wu X, Moinova H, Markowitz SD, Ding H, Hoeijmakers JH, Myung K (2008) Polyubiquitination of proliferating cell 
nuclear antigen by HLTF and SHPRH prevents genomic instability from stalled replication forks. Proc Natl Acad Sci U S A; 105(34):12411-6. Epub 2008 Aug 21.

133. Nelson JR, Lawrence CW, Hinkle DC (1996) Deoxycytidyl transferase activity of yeast REV1 protein. Nature; 382(6593):729-31.

134. Nelson JR, Lawrence CW, Hinkle DC (1996) Thymine-thymine dimer bypass by yeast DNA polymerase zeta. Science; 14;272(5268):1646-9.

135. Nelson SW, Benkovic SJ (2007) The T4 phage UvsW protein contains both DNA unwinding and strand annealing activities. J Biol Chem; 282(1):407-16.

136. Neylon C, Kralicek AV, Hill TM, Dixon NE (2005) Replication termination in Escherichia coli: structure and antihelicase activity of the Tus-Ter complex. Microbiol Mol Biol Rev; 69(3):501-26.

137. Nilsen T, Baglioni C. (1979) Unusual base-pairing of newly synthesized DNA in HeLa cells. J Mol Bio; 133(3):319-38.

138. Opresko PL, Cheng WH, Bohr VA (2004) Junction of RecQ helicase biochemistry and human disease. J Biol Chem; 279(18):18099-102.

139. Oue N, Mitani Y, Motoshita J, Matsumura S, Yoshida K, Kuniyasu H, Nakayama H, Yasui W (2006) Accumulation of DNA methylation is associated with tumor stage in gastric cancer. Cancer; 106(6):1250-9.

140. Pagès V, Fuchs RP (2003) Uncoupling of leading- and lagging-strand DNA replication during lesion bypass in vivo. Science; 300(5623):1300-3.

141. Parker JL, Ulrich HD (2009) Mechanistic analysis of PCNA poly-ubiquitylation by the ubiquitin protein ligases Rad18 and Rad5. EMBO J; 28(23):3657-66.

142. Postow L, Ullsperger C, Keller RW, Bustamante C, Vologodskii AV, Cozzarelli NR (2001) Positive torsional strain causes the formation of a four-way junction at replication forks. J Biol Chem; 276(4):2790-6.

143. Prakash L (1981) Characterization of postreplication repair in Saccharomyces cerevisiae and effects of rad6, rad18, rev3 and rad52 mutations. Mol Gen Genet; 184(3):471-8.

144. Prakash S, Johnson RE, Prakash L (2005) Eukaryotic translesion synthesis DNA polymerases: specificity of structure and function. Annu Rev Biochem; 74:317-53. 
145. Prakash S, Sung P, Prakash L (1993) DNA repair genes and proteins of Saccharomyces cerevisiae. Annu Rev Genet; 27:33-70

146. Prkarow JK, Constantinou A, Li JL, West SC, Hickson ID. (2000) The Bloom's syndrome gene product promotes branch migration of holliday junctions. Proc Natl Acad Sci U S A; 97(12):6504-8.

147. Ralf C, Hickson ID, Wu L (2006) The Bloom's syndrome helicase can promote the regression of a model replication fork. J Biol Chem; 281(32):22839-46.

148. Ramilo C, Gu L, Guo S, Zhang X, Patrick SM, Turchi JJ, Li GM (2002) Partial reconstitution of human DNA mismatch repair in vitro: characterization of the role of human replication protein A. Mol Cell Biol; 22(7):2037-46.

149. Robu ME, Inman RB, Cox MM (2001) RecA protein promotes the regression of stalled replication forks in vitro. Proc Natl Acad Sci U S A; 98(15):8211-8.

150. Rothstein R, Michel B, Gangloff S (2000) Replication fork pausing and recombination or "gimme a break. Genes Dev; 14(1):1-10.

151. Sancar A, Lindsey-Boltz LA, Unsal-Kaçmaz K, Linn S (2004) Molecular mechanisms of mammalian DNA repair and the DNA damage checkpoints. Annu Rev Biochem; 73:3985.

152. Schofield MJ, Hsieh P (2003) DNA mismatch repair: molecular mechanisms and biological function. Annu Rev Microbiol; 57:579-608.

153. Seigneur M, Bidnenko V, Ehrlich SD, Michel B (1998) RuvAB acts at arrested replication forks. Cell; 95(3):419-30.

154. Setlow RB, Carrier WL (1966) Pyrimidine dimers in ultraviolet-irradiated DNA's. J Mol Biol.1: 237-54.

155. Sheridan PL, Sheline CT, Cannon K, Voz ML, Pazin MJ, Kadonaga JT, Jones KA (1995) Activation of the HIV-1 enhancer by the LEF-1 HMG protein on nucleosome-assembled DNA in vitro. Genes Dev; 9(17):2090-104.

156. Shibutani S, Takeshita M, Grollman AP (1991) Insertion of specific bases during DNA synthesis past the oxidation-damaged base 8-oxodG. Nature; 349(6308):431-4. 
157. Shrivastav M, De Haro LP, Nickoloff JA (2008) Regulation of DNA double-strand break repair pathway choice. Cell Res; 18(1):134-47.

158. Singleton MR, Dillingham MS, Wigley DB (2007) Structure and mechanism of helicases and nucleic acid translocases. Annu Rev Biochem;76:23-50.

159. Singleton MR, Scaife S, Wigley DB (2001) Structural analysis of DNA replication fork reversal by RecG. Cell; 107(1):79-89.

160. Slocum SL, Buss JA, Kimura Y, Bianco PR (2007) Characterization of the ATPase activity of the Escherichia coli RecG protein reveals that the preferred cofactor is negatively supercoiled DNA. J Mol Biol; 367(3):647-64. Epub 2007 Jan 9.

161. Sogo JM, Lopes M, Foiani M (2002) Fork reversal and ssDNA accumulation at stalled replication forks owing to checkpoint defects. Science; 297(5581):599-602.

162. Stelter P, Ulrich HD (2003) Control of spontaneous and damage-induced mutagenesis by SUMO and ubiquitin conjugation. Nature; 425(6954):188-91.

163. Sun W, Nandi S, Osman F, Ahn JS, Jakovleska J, Lorenz A, Whitby MC (2008) The FANCM ortholog Fml1 promotes recombination at stalled replication forks and limits crossing over during DNA double-strand break repair. Mol Cell; 32(1):118-28.

164. Svoboda DL, Vos JM (1995) Differential replication of a single, UV-induced lesion in the leading or lagging strand by a human cell extract: fork uncoupling or gap formation. Proc Natl Acad Sci U S A; 92(26):11975-9.

165. Tatsumi K, Strauss B (1978) Production of DNA bifilarly substituted with bromodeoxyuridine in the first round of synthesis: branch migration during isolation of cellular DNA Nucleic Acids Res; 5(2):331-47.

166. Wu L, Chan KL, Ralf C, Bernstein DA, Garcia PL, Bohr VA, Vindigni A, Janscak P, Keck JL, Hickson ID. (2005) The HRDC domain of BLM is required for the dissolution of double Holliday junctions. EMBO J; 24(14):2679-87. Epub 2005 Jun 30.

167. U Torres-Ramos CA, Prakash S, Prakash L (2002) Requirement of RAD5 and MMS2 for postreplication repair of UV-damaged DNA in Saccharomyces cerevisiae. Mol Cell Biol; 22(7):2419-26. 
168. Ulrich HD (2005) Mutual interactions between the SUMO and ubiquitin systems: a plea of no contest.Trends Cell Biol; 15(10):525-32.

169. Ulrich HD (2005) The RAD6 pathway: control of DNA damage bypass and mutagenesis by ubiquitin and SUMO. Chembiochem; 6(10):1735-43.

170. Ulrich HD, Jentsch S (2000) Two RING finger proteins mediate cooperation between ubiquitin-conjugating enzymes in DNA repair. EMBO J; 19(13):3388-97.

171. Unk I, Hajdú I, Blastyák A, Haracska L (2010) Role of yeast Rad5 and its human orthologs, HLTF and SHPRH in DNA damage tolerance. DNA Repair (Amst); 9(3):25767

172. Unk I, Hajdú I, Fátyol K, Hurwitz J, Yoon JH, Prakash L, Prakash S, Haracska L (2008) Human HLTF functions as a ubiquitin ligase for proliferating cell nuclear antigen polyubiquitination. Proc Natl Acad Sci U S A; 105(10):3768-73.

173. Unk I, Hajdú I, Fátyol K, Szakál B, Blastyák A, Bermudez V, Hurwitz J, Prakash L, Prakash S, Haracska L (2006) Human SHPRH is a ubiquitin ligase for Mms2-Ubc13dependent polyubiquitylation of proliferating cell nuclear antigen. Proc Natl Acad Sci U S A; 103(48):18107-12.

174. von Kobbe C, Karmakar P, Dawut L, Opresko P, Zeng X, Brosh RM Jr, Hickson ID, Bohr VA (2002) Colocalization, physical, and functional interaction between Werner and Bloom syndrome proteins. J Biol Chem; 277(24):22035-44

175. Wagner R Jr, Meselson M (1976) Repair tracts in mismatched DNA heteroduplexes. Proc Natl Acad Sci U S A; 73(11):4135-9.

176. Wanka F, Mullenders LH, Bekers AG, Pennings LJ, Aelen JM, Eygensteyn J (1977) Association of nuclear DNA with a rapidly sedimenting structure. Biochem Biophys Res Commun; 74(2):739-47.

177. Ward JF (1990) The yield of DNA double-strand breaks produced intracellularly by ionizing radiation: a review. Int J Radiat Biol. 57(6):1141-50.

178. Watts FZ (2006) Sumoylation of PCNA: Wrestling with recombination at stalled replication forks. DNA Repair (Amst); 5(3):399-403. 
179. Webb MR, Plank JL, Long DT, Hsieh TS, Kreuzer KN (2007) The phage T4 protein UvsW drives Holliday junction branch migration. J Biol Chem; 282(47):34401-11.

180. West SC (1997) Processing of recombination intermediates by the RuvABC proteins. Annu Rev Genet; 31:213-44.

181. Wold MS (2007) Replication protein A: a heterotrimeric, single-stranded DNA-binding protein required for eukaryotic DNA metabolism. Annu Rev Biochem; 66:61-92.

182. Wood A, Garg P, Burgers PM (2007) A ubiquitin-binding motif in the translesion DNA polymerase Rev1 mediates its essential functional interaction with ubiquitinated proliferating cell nuclear antigen in response to DNA damage. $\mathrm{J}$ Biol Chem; 282(28):20256-63.

183. Wu L (2007) Role of the BLM helicase in replication fork management. DNA Repair (Amst); 6(7):936-44.

184. Wu L, Hickson ID (2003) The Bloom's syndrome helicase suppresses crossing over during homologous recombination. Nature; 426(6968):870-4.

185. Wu L, Hickson ID (2006) DNA helicases required for homologous recombination and repair of damaged replication forks. Annu Rev Genet; 40:279-306.

186. Wu L, Chan KL, Ralf C, Bernstein DA, Garcia PL, Bohr VA, Vindigni A, Janscak P, Keck JL, Hickson ID (2005) The HRDC domain of BLM is required for the dissolution of double Holliday junctions. EMBO J; 24(14):2679-87. Epub 2005 Jun 30.

187. Wu L, Hickson ID (2006) DNA helicases required for homologous recombination and repair of damaged replication forks. Annu Rev Genet; 40:279-306.

188. Yamada K, Miyata T, Tsuchiya D, Oyama T, Fujiwara Y, Ohnishi T, Iwasaki H, Shinagawa H, Ariyoshi M, Mayanagi K, Morikawa K (2002) Crystal structure of the RuvA-RuvB complex: a structural basis for the Holliday junction migrating motor machinery. Mol Cell; 10(3):671-81.

189. Yu SL, Johnson RE, Prakash S, Prakash L (2001) Requirement of DNA polymerase eta for error-free bypass of UV-induced CC and TC photoproducts. Mol Cell Biol; 21(1):1858. 
190. Yusufzai T, Kadonaga JT (2008) HARP is an ATP-driven annealing helicase. Science; 322(5902):748-50.

191. Zannis-Hadjopoulos M, Persico M, Martin RG (1981) The remarkable instability of replication loops provides a general method for the isolation of origins of DNA replication. Cell; 27(1 Pt 2):155-63.

192. Zhou BB, Elledge SJ (2000) The DNA damage response: putting checkpoints in perspective. Nature; 408(6811):433-9.

193. Zou H, Rothstein R. (1997) Holliday junctions accumulate in replication mutants via a RecA homolog-independent mechanism. Cell; 90(1):87-96. 


\section{Acknowledgement}

I would like to express my sincere thanks to my supervisor Dr. Haracska Lajos for providing me with a great research opportunity. His invaluable guidance and encouragement are a great help not only in the completion of this research but also in my future academic pursuits. I greatly appreciate the wonderful time working with him.

I would also like to thank Dr. Blastyak Andras, for his unconditional help and support. His mastery of science and devotion to research set a role model to me, and I will be conscious of his example in my whole life.

I owe my gratitude to the group members for creating such a friendly atmosphere. Especially I would like to express my gratitude to Illesne Kovacs Katalin, Fekete Ildiko and Notari Peterne for their extraordinary technical assistance, but above all, for their invaluable human understanding.

My special thanks to Himabindu Gali, for being at my side most of the time, listening to me and giving me unconditional support.

I also wish to thank warmly my dearest friend Turoczy Zoltan especially for his friendship, filling my $\mathrm{PhD}$ duration with enjoyable moments. I am also very thankful to all the talented individuals from ITC community, in particularly to the little Indian community in Szeged for making my stay in Hungary more memorable.

I greatly appreciate the support from office staff at the Institute of Genetics and the administrative staff from Biological Research Centre.

Finally, my deepest thanks to my family for bringing happiness into my life, giving me unconditional love, understanding, helping and encouraging all the time, which is necessary to ensure my success. 


\section{Summary}

Human HLTF (Helicase Like Transcription Factor) is a member of the Swi2/Snf2 family of ATP-driven molecular motor proteins. Like many members of Swi2/Snf2 family, HLTF does not exhibit a canonical DNA helicase activity but has an ATP hydrolysis-driven double stranded (ds) DNA translocase activity. The biological importance of HLTF is indicated by the finding that it has a role in replication of damaged DNA and preventing genome rearrangement, and in accord, it is considered as tumor suppressor. The discovery of the replication fork remodeling activity of HLTF, particularly its fork reversal activity, provided a mechanistic explanation for its role in template switch dependent error-free DNA damage bypass. However, a stalled replication fork contains several single-stranded (ss) DNA- and dsDNA-bound proteins such as RPA, RFC, PCNA, and replicative polymerase. How these proteins are displaced before the DNA remodeling occurs has been unknown.

We investigated if HLTF DNA remodeling activity is inhibited by a protein bound to stalled replication fork-like DNA structures. First, we wanted to rule out any specific proteinprotein interactions between HLTF and the DNA-bound protein, therefore we chose the E. coli E111Q EcoRI endonuclease mutant protein that is selectively defective in DNA cleavage but retained its sequence specific dsDNA binding activity. We generated various homologous replication fork-like DNA substrates containing EcoRI binding sites in the arms, to which we stoichiometrically bound E111Q EcoRI proteins as our gel mobility shift experiment confirmed. The remodeling of these protein-bound DNA structures can be followed by the appearance of $75 / 75$ or $30 / 30$ nucleotide-long double stranded DNAs that would arise upon fork reversal as described. In a control experiment, we used the Bloom helicase (BLM) for which a fork reversal activity has also been reported, and we detected that it was completely inhibited by binding of single E111Q EcoRI proteins to both arms. In contrast, we found that HLTF retained its fork reversal activity on such a substrate and only weak inhibition occurred. In addition, when the fork DNA contained only single EcoRI binding site in one of its arms, HLTF processed the leading or lagging strand-bound protein containing substrates equally well. These results suggested that during fork reversal, HLTF can displace bound E111Q EcoRI proteins from both leading and lagging arms. To confirm the actual removal of the E111Q protein and that it was dependent on 
the dsDNA translocase activity of HLTF we monitored the displacement of E111Q EcoRI protein from model replication fork by capturing displaced E111Q EcoRI protein on a labeled duplex DNA containing single EcoRI binding site. The displaced E111Q EcoRI was monitored by the appearance of protein bound trap DNA in gel mobility shift experiment. The appearance of band shift only observed with wild type HLTF but its absence in ATPase mutant HLTF supported that HLTF can actively remove E111Q EcoRI from modeled fork and this function is dependent on ATP dependent double strand DNA translocase activity.

Uncoupling of leading and lagging strand synthesis can frequently occur if the replication machinery encounters DNA lesions, which can lead to fork structures containing a ssDNA region that can become covered by ssDNA binding proteins such a RPA. Previous data indicated that some helicases such as BLM has the ability to remove the Rad51 protein bound to ssDNA, but one can not expect ssDNA-bound protein removal, which requires translocation on ssDNA, by a dsDNA translocase such as HLTF. To verify if these kind of ssDNA bound proteins can challenge the fork remodeling activity of HLTF, we generated a 15nt ssDNA gap region in the leading strand of modeled fork where a ssDNA binding protein like RPA or E.coli SSB can be successfully bound. Fork reversal assay on these kinds of substrates reveal that HLTF and BLM can successfully regress a fork even in the presence of ssDNA binding protein. On this special substrate, RPA displacement can be explained by the dsDNA translocase activity of HLTF, and this is consistent with a model that during fork reversal HLTF translocates on the parental duplex DNA when concertedly unwinds the arms of the fork and zips the parental stands and the nascent strands. RPA displacement can not be attributed to a potential interaction between HLTF and RPA since HLTF was also able to remove equally well the E. coli SSB protein from such a substrate. This finding indicates that on some complex DNA substrate, HLTF double-stranded DNA translocase action can also remodel a ssDNA binding protein. Taken together, these experiments provide evidence that HLTF can carry out coordinated protein displacement/DNA remodeling dual function at stalled replication forks. 
To provide evidence that HLTF can indeed remodel proteins expected to be present at a stalled replication fork, we examined if HLTF can overcome the inhibitory effect of the complex of PCNA and RFC bound to a model replication fork substrate. In control experiment, these DNA binding proteins completely inhibited fork reversal by BLM helicase. Importantly, however, HLTF was able to remodel the fork DNA substrate bound by these protein factors of the replication machinery.

In general, proteins in the Swi2/Snf2 family have been considered as chromatin remodeling enzymes for nucleosome displacement. However, for some members a special function was found such as for Mot1, which can displace the TATA box-binding protein; for HARP, which can rewind a stably unwound DNA; and for FancM, HLTF, and yeast Rad5, which exhibit fork reversal activity. The discovered coordinated protein displacing/DNA remodeling activity of HLTF further extends the repertoire of the enzymatic ability of this intensively examined protein family, and raises the question if other Swi2/Snf2 proteins exhibit similar activities. Moreover, we suggest that the protein displacing/DNA remodeling activity of HLTF can be important for genome stability as indicated by that in high percentage of cancers HLTF expression is either silenced or various Swi2/Snf2 domain deletion mutant HLTF proteins are expressed. 


\section{0. Összefoglalás}

Az emberi HLTF (Helicase-like transcripcion factor) a Swi2/Snf2 ATP-vezérelt molekuláris motorfehérjék családjának a tagja. Mint a Swi2/Snf2 család legtöbb tagjának, a HLTF-nek sincs kanonikus DNS helikáz aktivitása, de rendelkezik ATP-hidrolízis által vezérelt kettős szálú (ds) DNS transzlokáz aktivitással. A HLTF biológiai jelentőségét jelzi, hogy szerepet játszik a sérült DNS replikációjában és megakadályozza a genom átrendeződést, így egy tumor szupresszor fehérjének minősül. A HLTF replikációs villa-átalakító tevékenységének a felfedezése, különösen a villa visszafordító képessége, mechanikus magyarázatot nyújt a templát váltáson alapuló hiba mentes DNS átirására. Azonban az elakadt replikációs villához több egyszálú (ss) DNS-, és dsDNS-kötött fehérje kapcsolódik, mint például az RPA, RFC, PCNA, és a replikációs polimeráz. Eddig ismeretlen, hogy ezek a fehérjék milyen módon távolítódnak el, mielött a DNS templát váltás végbemegy.

Megvizsgáltuk, hogy a HLTF DNS átrendező aktivitását gátoljék-e azok a fehérjék, amelyek kötődnek az elakadt replikációs villa-szerü DNS struktúrákhoz. Először is, szerettük volna kizárni a konkrét fehérje-fehérje közötti kölcsönhatást a HLTF és a DNS-kötő fehérje kötött, ezért az E. coli E111Q EcoRI endonukleáz mutáns fehérjéjét választottuk, mely nem képes a DNS hasítására, de megőrizte a szekvencia specifikus dsDNS kötő aktivitását. Különböző homológ replikációs villa-szerü DNS szubsztrátokat készítettünk, melyek EcoRI kötöhelyeket tartalmaznak a rövid karokon, amihez sztöchiometrikus mennyiségben sikerült kötnünk az E111Q mutáns EcoRI fehérjét, amint azt a gél mobilitás eltolódási kísérletünk is megerősítette. Ezen fehérje-kötött DNS struktúrák átrendeződését a reakció során megjelenő 75/75 vagy 30/30 nukleotid hosszú dupla szálú DNS-ek megjelenésével tudjuk követni. A kontroll kísérletben a Bloom helikázt (BLM) használtuk, melyről szintén bebizonyították, hogy rendelkezik replikációs villa-visszafordító aktivitással, és kimutattuk, hogy az E111Q mutáns EcoRI fehérje kötődése gátolta ezt az aktivitását. Ezzel szemben azt találtuk, hogy a HLTF megőrizte villa visszafordító képességét az EcoRI kötődése mellett, és csak kismértékű gátlás volt megfigyelhető . Ezen túlmenően, amikor a villa DNS-en csak az egyik kar tartalmazott EcoRI kötőhelyet, a HLTF mind a vezető, mind a lemaradó szálnak megfelő karon egyformán jól 
működött. Ezek az eredmények azt mutatják, hogy a HLTF a replikációs villa visszafordítása közben egyaránt képes eltávolítani az E111Q EcoRI fehérjét a vezető és lemaradó szálról. Hogy megerősítsük az E111Q fehérje tényleges eltávolítását, és azt, hogy ez a HLTF dsDNS transzlokáz aktivitásától függ, figyelemmel kísértük az E111Q EcoRI fehérje modell replikációs villáról történő eltávolítását egy jelölt, EcoRI kötőhelyet tartalmazó dsDNS-hez való kötődésével. Az eltávolított E111Q EcoRI fehérjét gél mobilitás eltolódási kísérletben követtük nyomon, és a fehérje-kötött DNS-el mutattuk ki. A fehérje-kötött DNS csak a vad típusú HLTF-el jelent meg, az ATPáz mutánssal nem, ami arra utal, hogy az EcoRI fehérje eltávolítása a modell replikációs villáról a HLTF ATP függő dsDNS transzlokáz aktivitásának köszönhető.

A vezető és lemaradó szál szintézise a leggyakrabban különválik akkor, ha a replikációs apparátus egy DNS hibához ér. Ez a folyamat ssDNS kialakulásához vezet, amit ssDNS kötő fehérjék, mint az RPA és a Rad51 képesek megkötni. Korábbi adatok alapján ismerünk olyan helikázokat, mint például a BLM, melyek képesek eltávolítani az ssDNS-hez kötött Rad51 fehérjét, de nem tudunk olyan fehérjéröl, mely ssDNS kötött fehérjét képes eltávolítani dsDNS transzlokáz aktivitása révén.. Annak vizsgálatára, hogy ilyen mechanizmusra képes a HLTF fehérje, létrehoztunk egy $15 \mathrm{nt}$ hosszú ssDNS régiót a modell replikációs villa vezető szálán, ahová az ssDNS kötő fehérjék, mint az RPA vagy az E. coli SSB kötődni tudnak. Villa visszafordító kísérletben kimutattuk, hogy mind a HLTF mind a BLM sikeresen visszafordította a villát ssDNS kötő fehérje jelenlétében. Ezen a speciális szubsztráton az RPA-t a HLTF dsDNS transzlokáz aktivitása révén képes eltávolítani ami összhangban áll azzal a modellel, mi szerint a villa visszafordítás során a HLTF az újonnan szintetizált szálakat leválasztja az anyai szálról, majd összehibridizálja azokat. Az RPA eltávolítás nem tulajdonítható a HLTF és RPA közötti kapcsolatnak, mivel a HLTF az E. coli SSB fehérjét is ugyan ilyen hatékonyan képes eltávolítani az azonos szubsztrátról.. Ez az eredmény azt jelzi, hogy bizonyos bonyolult DNS szubsztrátokon, a HLTF kettős szálú DNS transzlokáz aktivitása is képes az ssDNS-kötött fehérjék eltávolítására. Az eredményeket összevetve, kísérleteink bizonyítják, hogy a HLTF koordinált fehérje eltávolító/ DNS átrendező kettős funkcióval rendelkezik az elakadt replikációs villánál. 
Annak érdekében, hogy kimutassuk, hogy a HLTF valóban képes olyan fehérjék eltávolítására, amelyek a replikációs villában jelen vannak, megvizsgáltuk, hogy a PCNA és RFC komplex milyen hatással van a HLTF aktivitására modell villa szubsztráton. A kontroll kísérletben, ezek a DNS-kötő fehérjék teljes mértékben gátolták a BLM helikáz villavisszafordító aktitását. A HLTF viszont képes volt átalakítani ezen replikáció során jelen lévő fehérjék által kötött villa szubsztrátot.

Általánosságban a Swi2/Snf2 családba sorolt fehérjékre az jellemző, hogy a nukleoszóma elmozdulását a végzik a kromatin remodelling során. Azonban néhány tagjuk olyan különleges funkcióval rendelkezik, mint például a MOT1, amely leszorítja a DNS-ről a TATA box-kötő fehérjét, a HARP, ami képes összetekercselni a letekert DNS-t, és a FancM, HLTF, és az élesztő Rad5, amelyek replikációs villa-visszafordító képességgel rendelkeznek. A HLTF újonnan felfedezett koordinált fehérje eltávolító/DNS átrendező kettős funkciója tovább bővíti ezen fehérjék enzimatikus repertoárját és felveti a kérdést, miszerint más Swi2/Snf2 fehérjék is mutatnak-e hasonló aktivitást. Továbbá valószínüsítjük, hogy a HLTF koordinált fehérje eltávolító/DNS átrendező kettős funkciója fontos lehet a genom stabilitásának megőrzésében, amit az is jelez, hogy a rák egyes formáiban a HLTF expressziója csökkent, vagy különböző Swi2/Snf2 domén deléciós mutáns HLTF fehérje van jelen. 